\title{
Carlos
}

\author{
Lozano Ascencio (coord)
}

Prólogo de Delia Crovi Druetta

\section{La construcción del acontecer de riesgos y de catástrofes}

Cuadernos Artesanos de Comunicación / 82

ULL

Universidad de La Laguna

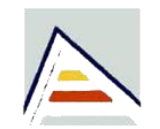

Universitat d'Alacant Universidad de Alicante
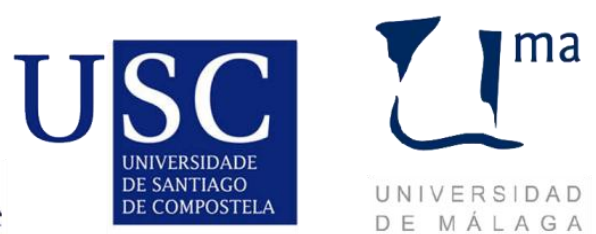

UNIVERSIDAD DE M ÁLAGA

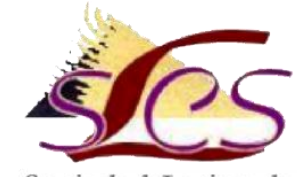

Sociedad Latina de

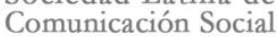


Presidencia: José Luis Piñuel Raigada (UCM)

Secretaría: Concha Mateos (URJC)

Bernardo Díaz Nosty (Universidad de Málaga, UMA)

Carlos Elías (Universidad Carlos III de Madrid, UC3M)

Javier Marzal (Universidad Jaume I, UJI)

José Luis González Esteban (Universitas Miguel Hernáncez de Elche, UMH)

José Luis Terrón (Universidad Autónoma de Barcelona, UAB)

José Miguel Túñez (Universidad de Santiago, USC)

Juan José Igartua (Universidad de Salamanca, USAL)

Marisa Humanes (Universidad Rey Juan Carlos, URJC)

Miguel Vicente (Universidad de Valladolid, UVA)

Miquel Rodrigo Alsina (Universidad Pompeu Fabra, UPF)

Núria Almiron (Universidad Pompeu Fabra, UPF)

Ramón Reig (Universidad de Sevilla, US)

Ramón Zallo (Universidad del País Vasco, UPV-EHU)

Victoria Tur (Universidad de Alicante, UA)

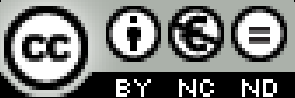

* Queda expresamente autorizada la reproducción total o parcial de los textos publicados en este libro, en cualquier formato o soporte imaginables, salvo por explícita voluntad en contra del autor o autora o en caso de ediciones con ánimo de lucro. Las publicaciones donde se incluyan textos de esta publicación serán ediciones no comerciales y han de estar igualmente acogidas a Creative Commons. Harán constar esta licencia y el carácter no venal de la publicación.

* La responsabilidad de cada texto es de su autor o autora.

* Los artículos que componen este volumen han pasado un proceso de revisión por pares ciegos. Los coordinadores agradecemos encarecidamente la participación en dicho proceso a José María Bernardo (U. de Valencia), Alicia de Lara (U. Miguel Hernández de Elche), Josep-Vicent Gavaldà (U. de Valencia), Virginia Guarinos (U. de Sevilla), Jesús Jiménez Varea (U. de Sevilla), Kiko Mora (U. de Alicante), Miguel Ángel Pérez-Gómez (U. de Sevilla), Ana Sedeño (U. de Málaga) y Luz Souto (U. de Valencia). 
Carlos Lozano Ascencio (coord.)

Prólogo de Delia Crovi Druetta

La construcción del

acontecer de riesgos y de catástrofes

Cuadernos Artesanos de Comunicación / 82

ULL

Universidad de La Laguna
Universitat d'Alacant Universidad de Alicante
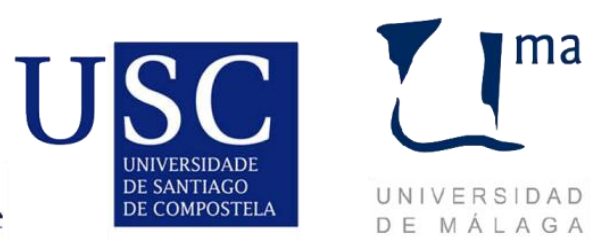

UNIVERSIDAD

DE MÁLA A

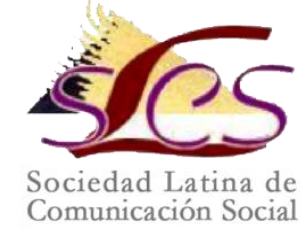


$82^{\circ}$ La construcción del acontecer de riesgos y de catástrofes

Carlos Lozano Ascencio |

Precio social: $8,05 € \mid$ Precio en librería. 10,50€ |

Editores: Javier Herrero y Alberto Ardèvol Abreu

Diseño: F. Drago

Ilustración de portada: Ilustración de portada: Fragmento del cuadro Árboles y viento, de Juan Davo (sin fecha).

Imprime y distribuye: F. Drago. Andocopias S. L.

c/ La Hornera, 41. La Laguna. Tenerife.

Teléfono: 922250554 | fotocopiasdrago@,telefonica.net

Edita: Sociedad Latina de Comunicación Social - edición no venal

- La Laguna (Tenerife), 2015 - Creative Commons

(http://www.revistalatinacs.org/09/Sociedad/estatutos.html)

Catálogo: http://www.cuadernosartesanos.org

Protocolo de envío de manuscritos con destino a CAC:

http://www.cuadernosartesanos.org/protocolo.html

Descargar $p d f:$ http://www.cuadernosartesanos.org/\#82

ISBN - 13: 978-84-16458-02-8

DL: TF-409-2015

DOI: $10.4185 / \operatorname{cac} 82$ 


\section{Índice}

Prólogo. Delia Crovi Druetta Universidad Nacional Autónoma de México .............7

Introducción: La construcción del acontecer de riesgos y de catástrofes.

Carlos Lozano Ascencio Universidad Rey Juan Carlos. 11

1. La construcción de los discursos sobre catástrofes de origen natural en los informativos de las televisiones en España. Enrique Morales

Corral. U-Tad Universidad Camilo José Cela. Ma Luisa Sánchez

Calero. Universidad Complutense de Madrid. Carlos Lozano

Ascencio. Universidad Rey Juan Carlos.

2. Las catástrofes en las revistas semanales brasileñas: evidencias y

silenciamientos. Márcia Franz Amaral. Universidade Federal

de Santa Maria

3. Las prospecciones petrolíferas en el Golfo de Valencia en la prensa española. M ${ }^{\mathrm{a}}$ Teresa Mercado Sáez y Fernando Sahuquillo Verdet. Universidad CEU Cardenal Herrera.

4. Humanismo y desastres naturales: el caso de Omaira Sánchez y la erupción del Nevado del Ruiz. Sergio Mena Muñoz.

Universidad Nebrija

5. Comunicación de crisis y lenguaje: la erupción submarina en la Isla

de El Hierro. Araceli Álvarez Díaz. Universidad de La Laguna

6. Plataformas antifracking y construcción mediática del riesgo. Àngels Álvarez Villa, Ángel Castaños Martínez y M⿳a Teresa Mercado Sáez. Universidad CEU Cardenal Herrera

7. La sociedad del Riesgo en la ficción televisiva tras el 11 de Septiembre. Delicia Aguado Peláez. Universidad País V asco

8. La "pobreza energética" en el relato periodístico sobre la crisis en España. Ma José Pou Amérigo y Estrella Israel Garzón.

Universidad Cardenal Herrera-CEU.

9. La crisis económica en España y la accidentalidad laboral: análisis cuantitativo en la prensa escrita. Sergio Arce García.

Universidad Internacional de La Rioja (UNIR) 


\title{
La construcción del acontecer de riesgos y de catástrofes
}

\begin{abstract}
Las construcciones narrativas del acontecer de riesgos y de catástrofes son los relatos que elaboran los medios de comunicación durante las coberturas informativas que, con grandes alardes técnicos, describen las quiebras del acontecer. Los medios no registran la totalidad de eventualidades catastróficas que acaecen, sino más bien seleccionan, jerarquizan y profundizan en aquellos acontecimientos que más importancia tienen de acuerdo a sus propios criterios periodísticos.
\end{abstract}

En la actualidad existen y se perciben mucho más catástrofes que en otros tiempos históricos; esto se explica al considerar que no sólo tenemos mucha más información que antes, sino que también nuestras sociedades son infinitamente mucho más propensas a padecer trastornos destructivos; la fragilidad social se ha incrementado a tales niveles, que un fenómeno en apariencia inocuo (piénsese en una granizada) hoy día puede ser representado en muchos relatos como si se tratara de trastornos con efectos más catastróficos que en otros tiempos.

Este libro reúne catorce artículos en donde se analizan los relatos mediáticos de la prensa, telediarios, revistas semanales y programas de ficción, de España, Brasil, Colombia y en series televisas norteamericanas, derivados de situaciones de riesgo y de catástrofes.

\section{Keywords}

Comunicación de Riesgo, Catástrofe, Discurso Mediático, Sociedad del Riesgo, Crisis.

\section{Forma de citar este libro}

Autor del capítulo "Xxxxx", en Carlos Lozano Ascencio (2015): La construcción del acontecer de riesgos y de catástrofes. Cuadernos Artesanos de Comunicación, 82. La Laguna (Tenerife): Latina. 


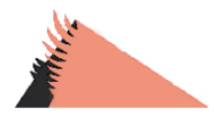 \\ Prólogo}

Delia Crovi Druetta. Profesora del Centro de Estudios en Comunicación, Universidad Nacional Autónoma de México. Presidenta a la Asociación Latinoamericana de Investigadores de la Comunicación. crovidelia@gmail.com

厂 OS RIESGOS y catástrofes nos sorprenden cada vez más en el acontecer cotidiano. Se trata de amenazas que no hemos calculado en lo personal y tampoco han sido previstas en marcos sociales más amplios. Sin embargo, esta falta de previsión no es la respuesta que podemos esperar ante avisos reiterados de lo que puede llegar a suceder con el desbordamiento de fuerzas naturales o el despliegue de causas de otra índole. Cuando las catástrofes son ya un hecho, interfieren tanto en nuestros planes personales, como en los programas locales, regionales o nacionales de desarrollo locales, amedrentando nuestra seguridad y nuestro futuro.

Las naciones y las personas parecemos ser refractarias a ciertos avisos naturales o sociales y nos colocamos en una frágil situación de no pensar en los riesgos, como si no nos fueran a tocar, como si esas catástrofes sólo pertenecieran al ámbito de la ficción, o al menos de nuestra ficción personal creada en torno a coordenadas de seguridad, confort, planeación de nuestras actividades productivas y recreativas. No obstante, cada vez más los riesgos son parte constitutiva de nuestras vidas y debemos comenzar a considerarlos en planes personales y sociales. Deben ir incorporándose como una coordenada más de planeación para garantizar, no su ausencia total, sino un manejo asertivo de las catástrofes. 
La construcción del acontecer de riesgos y de catástrofes es una obra coordinada por Carlos Lozano Ascencio, profesor de la Universidad Rey Juan Carlos de España, quien desde hace ya varios lustros se ha dedicado a investigar las narrativas mediáticas en torno a temas de riesgos y catástrofes naturales. Valorar estos acontecimientos, sus repercusiones, su impronta social y medioambiental, le han llevado a sostener que existen riesgos previsibles, $y$ otros sorpresivos o imposible de prevenir. También ha podido valorar que estos acontecimientos, cada vez más, responden a la intervención irresponsable de seres humanos despreocupados por el futuro, por la prevención y las consecuencias de la falta de rigor en la planeación de algunas actividades o servicios.

Este contexto de despreocupación y irresponsabilidad está fuertemente vinculado a la labor de los medios de comunicación, análogos y digitales, en los que esperamos encontrar alguna de las funciones básicas que los definen: reportar los hechos catastróficos con la mayor precisión posible en términos de sus causales y consecuencias; divulgar conocimientos en torno a los mismos que lleven a contar con una mirada preventiva y vigilante. Preventiva, ante hechos futuros de características similares, y vigilantes de las actividades de esos seres humanos despreocupados o irresponsables, que desdeñan la fuerza de la naturaleza y las condiciones extremas en que esas fuerzas son violentadas, en muchas ocasiones, por causas políticas y económicas.

En el libro coordinado por Carlos Lozano Ascencio, catorce autores analizan relatos mediáticos de la prensa, telediarios, revistas semanales y programas de ficción, de España, Brasil, Colombia y en series televisas norteamericanas, derivados de situaciones de riesgo y catástrofes. Se trata de un panorama amplio de análisis que nos permite leer, con detalle, aquellos elementos que llevan a construir esos relatos. Más allá de que cada país responde a una lógica periodística diferente, producto no sólo de su historia y su cultura sino de las prácticas profesionales que se ejercen en cada caso, podemos ver que existen coincidencias y también divergencias sobre la vocación de narrar lo acontecido, de valorar los riesgos, de medir las consecuencias de los acontecimientos catastróficos y de brindar elementos preventivos para el futuro. 
Aún con su inevitable dosis de incertidumbre, esperamos que los medios puedan ofrecer argumentos para la vigilancia social, que impidan acciones despreocupadas o irresponsables. Esperamos también que, como afirma Alfred Schütz ${ }^{1}$, pueden acercar a sus audiencias el conocimiento científico hacia áreas de significación cercanas a sus intereses y necesidades comunicativas. Es decir, divulgar de manera asequible ese conocimiento científico, poniéndolo a disposición de quienes pueden ser objeto de las consecuencias de las catástrofes.

Pasar de la percepción del riesgo al manejo adecuado, personal y social, de una catástrofe, necesita de la concurrencia de los medios, de esa suerte de vasos comunicantes entre el conocimiento científico y el intuitivo, que permitirá a las audiencias estar advertidas para vigilar y actuar ante las causas que las originan.

Berger y Luckmann" afirman: "El universo simbólico también ordena la historia y ubica todos los acontecimientos colectivos dentro de una unidad coherente que incluye el pasado, el presente y el futuro". Los medios, que son parte fundamental en la construcción de ese universo simbólico, pueden alimentar la dimensión histórica, aportando datos del pasado y el presente, que llevan a fortalecer las decisiones del futuro. De eso se trata esta obra: de los mecanismos mediáticos para evitar que los riesgos culminen, sin más, en situaciones catastróficas. Nada más oportuno que estas contribuciones en los en los que estamos viviendo, cuando las catástrofes no acaban de sorprendernos por su magnitud y persistencia.

México, D. F. Ciudad Universitaria, mayo de 2015.

\footnotetext{
${ }^{1}$ Schütz, A. 1973. Estudios sobre teoría social. Buenos Aires, Argentina, Amorrortu ${ }^{2}$ Berger P. y T. Luckmann. 1998. La construcción social de la realidad. Buenos Aires, Amorrortu, pág. 31.
} 



\title{
Introducción: La construcción del acontecer de riesgos y de catástrofes
}

\author{
Carlos Lozano Ascencio. Univesidad Rey Juan Carlos. \\ carlos.lozano@urjc.es
}

T OS MEDIOS de comunicación construyen el acontecer de 1 riesgos y catástrofes sin registrar la totalidad de las que acaecen, sino seleccionando, jerarquizando y profundizando en aquellas "quiebras del acontecer" a las que más importancia conceden de acuerdo a sus criterios periodísticos. La noción de "quiebras del

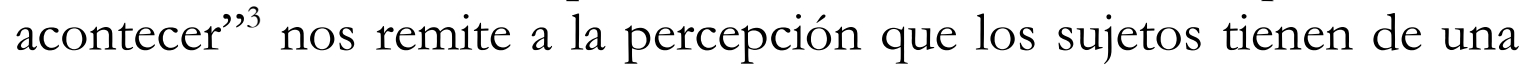
ruptura que sucede en el transcurso del acontecer. Dicha percepción les afecta en el control (cognitivo y práctico) sobre su entorno, llevándoles a una representación de desorden espacial y temporal, es decir, a una sensación de inseguridad.

La información sobre catástrofes no debería ser una información catastrófica; sin embargo, siempre ha resultado muy difícil hacer una distinción clara entre el acontecer que cambia y su percepción: el estado de ánimo que así se produce varía según los cambios sean previstos o no lo sean, y según se sienta más o menos implicado el sujeto ante ellos. Un cambio inesperado y una implicación alta, llevan a reacciones de urgencia, mientras que un cambio anticipado y una implicación baja no las conllevan. La espectacularización frecuente de los discursos periodísticos ("catastrofismo") tiende a incrementar tanto la sorpresa (lo inesperado) como la implicación (lo cercano).

\footnotetext{
${ }^{3}$ Piñuel, Gaitán y Lozano. (2013). Confiar en la prensa o no. Un método para el estudio de la construcción mediática de la realidad. Salamanca, Ed. Comunicación Social.
} 
La información periodística de catástrofes suele despertar inquietud ante los riesgos e inseguridad ante el entorno por la implicación inducida entre quienes se exponen a ella, ya sea por el atractivo de las imágenes o porque se sienten concernidos. Sin embargo, la contemplación de la inestabilidad relatada en los discursos informativos sobre catástrofes, no lleva necesariamente a los receptores a procesar esa información como conocimiento seguro y digno de ser socialmente compartido. Así, sería de desear que la información de catástrofes, no provoque en los receptores un estado de estupor o de perplejidad permanente ante los riesgos, sino una actitud proporcional de alerta y de resiliencia. En este sentido, los medios de comunicación tienen mucha responsabilidad a la hora de incentivar puntos de vista desconcertantes entre la gente, debido a que estamos muy habituados a percibir grandes cantidades de información pertenecientes a muchas clases de situaciones de inestabilidad, que saturan los límites de nuestras capacidades cognitivas para procesar correctamente esos datos.

En la actualidad existen y se perciben mucho más catástrofes que en otros tiempos históricos; esto se explica al considerar que no sólo tenemos mucha más información que antes, sino que también nuestras sociedades son infinitamente mucho más propensas a padecer trastornos destructivos; la fragilidad social se ha incrementado a tales niveles, que un fenómeno en apariencia inocuo (piénsese en una granizada) hoy día puede ser representado en muchos relatos como si se tratara de trastornos con efectos más catastróficos que en otros tiempos.

Las nuevas tecnologías eliminan las barreras del tiempo y el espacio y acercan los acontecimientos a los sujetos receptores facilitando la experimentación a distancia de situaciones de inestabilidad social. Daría la impresión de que los receptores estuvieran en el lugar de los hechos, como si también fueran posibles víctimas, sin advertir la existencia de las mediaciones (comunicativas y técnicas) que les permiten acercarse, en tiempo y en espacio, a los escenarios de los hechos. En este sentido, los medios de comunicación no aportan información rigurosa con sus discursos genéricos sobre las quiebras del acontecer; más bien, brindan a las audiencias el acceso a "experimentar la inestabilidad mientras esta se produce" y, en 
consecuencia, contribuyen a cambiar la "percepción social de los peligros" afectando a nuestra capacidad de resiliencia.

Si los relatos mediáticos que construyen el acontecer de riesgo y de catástrofes ayudan a las audiencias a percibir con el mismo nivel de relevancia las vulnerabilidades ajenas y las propias, dicha experiencia es debida a las mediaciones comunicativas. La vulnerabilidad a distancia existe y puede entenderse como una disponibilidad generalizada (que va arraigando culturalmente) para compartir el sentimiento de indefensión (sentirse indefenso sin serlo o adjudicarse esa experiencia). Cualquier sociedad contemporánea puede llegar a convertirse en una sociedad "tele-vulnerable", pero no siempre ocurre de la misma manera, depende mucho de las "mediaciones" (selección, jerarquización, temporalidad, extensión de los tratamientos informativos en los discursos dedicados a los riesgos) y también depende de los grados de implicación con los que se compromete a los receptores al percibir dicha información. Los sujetos que se sienten "tele-vulnerables" no son posibles víctimas mortales ni futuros damnificados directos, casi siempre son sólo una audiencia mediática consternada, que se siente aludida, y que reacciona más de manera visceral que racional. Lo más importante de la vulnerabilidad a distancia no son las diferentes reacciones de los espectadores que se consideran aludidos, sino el que dicha forma de comunicar los riesgos favorece, sobre todo, la percepción socialmente compartida de situaciones de incertidumbre sin motivar la participación de los ciudadanos por aprender a afrontar futuras eventualidades catastróficas.

En este libro el lector encontrará nueve relatos a propósito de las construcciones mediáticas de quiebras del acontecer de riesgo y de catástrofes desde muy variadas perspectivas. 



\title{
La construcción de los discursos sobre catástrofes de origen natural en los informativos de las televisiones en España
}

\author{
Enrique Morales Corral - Universidad Camilo José Cela \\ mors800@hotmail.com
}

\section{Ma Luisa Sánchez Calero - Universidad Complutense de Madrid mlusaca@,ccinf.ucm.es}

\section{Carlos Lozano Asencio - Universidad Rey Juan Carlos carlos.lozano@urjc.es}

Resumen: El presente capítulo ofrece un análisis sobre los discursos que los principales medios de comunicación audiovisuales españoles realizan sobre las catástrofes de origen natural ocurridas en España. Para ello se recogieron 220 piezas informativas durante un año natural, entre el verano del 2013 y el verano del 2014, y se realizaron dos grupos de discusión, uno formado por periodistas especializados, con el fin de que aporten su experiencia directa sobre el fenómeno a estudiar; y otro, formado por técnicos especialistas en catástrofes, aportando sus conocimientos desde las situaciones de riesgo y sus relaciones con los medios.

Se analizar la estructura interna de las noticias con el objetivo de averiguar el tratamiento que los medios realizan en este tipo de 
situaciones. También se comprueba la calidad periodística. El análisis de las noticias se realizó mediante un protocolo específico bajo soporte del programa informático de análisis estadístico (SPSS), mientras que los grupos de discusión fueron analizados cualitativamente mediante el programa informático de relaciones de discursos (Atlas.ti).

Las conclusiones abordan los problemas de los tres objetos a analizar, conformando un corpus que nos ha permitido una triple visualización de los discursos. Hemos podido triangular los resultados aportando una perspectiva adecuada para su análisis, y consiguiendo interesantes recomendaciones a todos los sectores involucrados en este tipo de noticias.

Palabras clave: comunicación de riesgo, discurso mediático periodístico, riesgos y catástrofes de origen natural.

\section{Introducción}

— STA COMUNICACIÓN forma parte de la presentación de 1 resultados de un proyecto de investigación realizado en el 2014, bajo la financiación de la Fundación Mapfre: Ayudas a la Investigación Ignacio H. de Larramendi y titulado: La construcción del mensaje sobre riesgos naturales en los medios de comunicación, realizado por los firmantes.

La investigación se sustentó en la necesidad de profundizar en cómo las cadenas de televisión españolas, elaboran las noticias relacionadas con los riesgos y las catástrofes de origen natural. La tendencia es que cada vez afectan más a la sociedad y estamos más sensibilizados ante ellos. Los medios son conscientes, y cubren estas noticias con mayores medios técnicos, describiendo lo acontecido (Piñuel, J. L., Gaitán, J. A. y Lozano C.: 2013).

Uno de los primeros puntos de partida que tuvimos en cuenta es que los medios no cubren todas las noticias, sino que jerarquizan aquellas que consideran más importantes según sus criterios periodísticos, algo habitual en la mayoría de las redacciones de todo El Mundo. Nos encontramos por lo tanto ante un primer filtro, una primera selección 
de las noticias, que reúne lo que determinados medios consideran noticiable y "digno" de ser emitido.

Un segundo punto de referencia es que la información de catástrofes no es (ni debería ser) una información catastrófica. Siempre ha sido difícil distinguir las referencias entre una situación de estas características y el estado de ánimo que se produce del visionado de la misma. Pero suele predominar la creencia de que la sola emisión de noticias sobre catástrofes aumenta el alarmismo social sobre los mismos (Lozano, 2009: 9).

Y un tercer punto es que en la actualidad los medios de comunicación se han constituido en la principal fuente de información en materia de percepción de riesgos según afirman (Major y Atwood 2004: 295). Una influencia que resulta clave a la hora de asociar el concepto de riesgo con determinadas características y asignarles una mayor o menor importancia, tal y como se deduce de los trabajos realizados desde la Agenda-Setting (McCombs, 2005) y las teorías del encuadre o framing (Hansen 2011: 15).

\section{Objetivos}

La intención de esta investigación es ver cómo construyen los medios de comunicación españoles los mensajes sobre riesgos y catástrofes de origen natural en España, a través de los formatos utilizados. Pero también ver cómo se reconstruyen narrativamente los trastornos catastróficos que más nos impactan, nos involucran y nos interesan, a través del framing utilizado.

Un tercer punto importante es conocer el tratamiento argumentativo que los mediadores realizan a la hora de elaborar las noticias relacionadas. Es decir, intentaremos analizar cómo es la estructura que han construido.

Por último, un último objetivo es el de confrontar los tres puntos anteriores con la opinión de los expertos (científicos, divulgadores y técnicos) y periodistas especializados, para poder elaborar un diagnóstico conjunto o triangulación. 
Este artículo describe brevemente cada uno de estos cuatro objetivos ya que para conocerlo en profundidad habría que acceder a la lectura del informe completo.

\section{Metodología}

Se ha optado por un triple análisis: cuantitativo, cualitativo y de triangulación, que permita obtener una visión amplia sobre el objeto de estudio.

En la parte cuantitativa se ha realizado un análisis mediante protocolo específico (24 preguntas) de 220 piezas informativas recogidas durante un año (de junio del 2013 a junio del 2014), en los tres principales grupos de comunicación en España, representados en los canales: TVE, Cuatro y Antena

El criterio de selección de las piezas informativas viene dado por las referencias al posible riesgo de padecer o al padecimiento ya consumado de trastornos, es decir eventualidades catastróficas o de quiebras del acontecer, recogiéndose un total de 550 registros. Es decir, los análisis cuantitativos no serán sobre las piezas recogidas directamente (220), sino sobre los eventos ocurridos en ellas, que suman 550 .

El objetivo del protocolo ha sido indagar en cómo se construyen narrativamente los mensajes sobre los riesgos de las catástrofes de origen natural. Para ello se estructuró en varias partes:

-los datos sobre la identificación de la pieza televisiva

-los datos sobre el análisis del trastorno (lo que altera o puede alterar la estabilidad)

-los datos sobre la estructura narrativa del trastorno

En la parte cualitativa se optó por la realización de dos grupos de discusión. Esta técnica ha permitido obtener un conocimiento más aproximado de la realidad social que se investiga mediante la comunicación que se establece (Gaitán y Piñuel, 1998: 122). Bajo esta premisa se intenta crear una representación equilibrada de una situación social en un grupo artificial, creado expresamente y siendo importante la falta de relación entre sus miembros, o, al menos, no 
muy directa, porque podría enturbiar la realización de los procesos del discurso creado. Pretendemos captar las necesidades, intereses y preocupaciones individuales y grupales de sus miembros, con el propósito de construir un discurso válido a nuestros intereses, que sirva de complemento a nuestro análisis cuantitativo. Se trata de ver si ambos grupos refutan o critican nuestras conclusiones cuantitativas, ver cuál es su punto de vista sobre diversos temas en los cuales los miembros poseen información válida y útil para nosotros.

Uno de los grupos de discusión formado por Expertos, divulgadores y técnicos se expresaron en relación a los avances científicos y su relación con los medios de comunicación, así como discutieron sobre aquellas posibles mejoras en la divulgación científica entre la población. El otro grupo se encontraba formado por Periodistas especializados, que intercambiaron opiniones sobre la emisión que los medios españoles hacían en la actualidad sobre las situaciones de riesgo y catástrofes de origen natural .

Para el análisis del discurso se usó el programa informático Atlas.ti, a través del cual se crea un listado de códigos, o estructuras temáticas, que constituyen los puntos analizados. Se trata de simplificar los elementos, de obtener datos simples (códigos) a partir de datos complejos (el discurso).

La triangulación de técnicas permite relacionar tres fuentes de datos: la parte cuantitativa, el discurso de los expertos y el discurso de los periodistas, con el objeto establecer unas conclusiones más ajustadas y coherentes en función de los datos recogidos.

\section{Resultados \\ 4.1 Cuantitativo}

En este apartado se va a comentar brevemente el análisis cuantitativo de las 220 piezas informativas recogidas de los telediarios españoles de: TVE, Cuatro y Antena3. En total, se encontraron en ellas 550 eventos de riesgo o provocados por catástrofes de origen natural, que fueron analizadas mediante un protocolo de 24 preguntas, formando una base en el programa informático SPSS. 


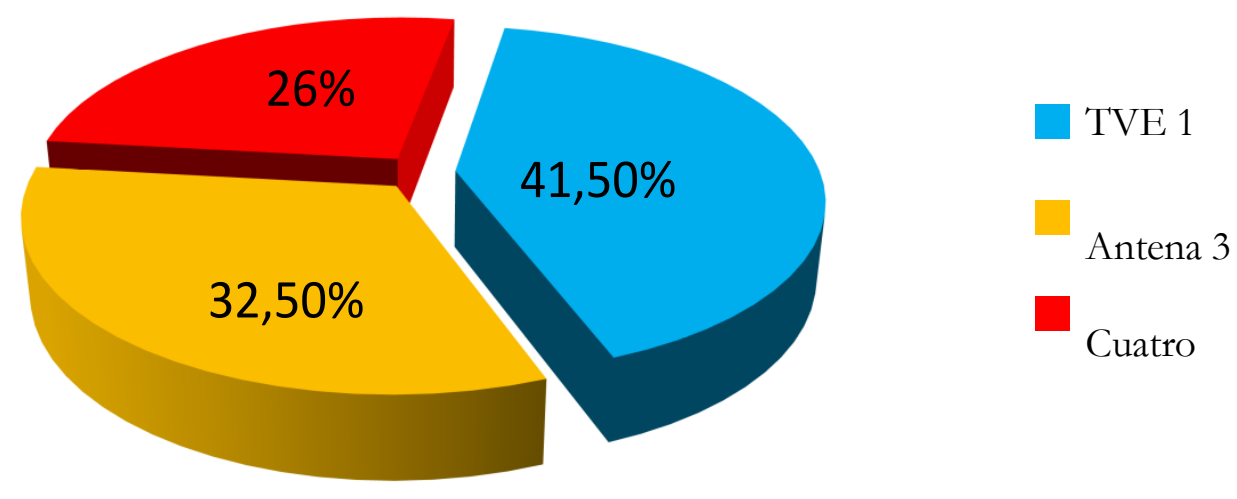

Gráfico 1: Distribución por canal de televisión. Fuente: elaboración propia

No existen diferencias sustanciales entre las cadenas en España a la hora de hablar de noticias de riesgo o catástrofes cuando cuantificamos el número de eventos. Es decir, si analizamos los datos del Gráfico 1 Distribución por canal de televisión, podemos observar que los porcentajes son muy parecidos en los tres canales de televisión analizados.

Aunque cabría esperar una mayor disparidad en los contenidos y sus cantidades entre unas cadenas y otras, hay que decir que cuando la actualidad informativa se impone, ésta siempre tiene su reflejo en todos los telediarios de todas las cadenas. Sólo TVE muestra unos datos superiores al resto, haciendo gala de su cariz público.

No existen tampoco diferencias sustanciales entre las cadenas si tenemos en cuenta que su gestión sea privada o pública en España. El Gráfico 2 Distribución por tipo de gestión, es muy parecido al 1. Al final existe un reparto más o menos equilibrado de eventos entre los diferentes tipos de canales de televisión. Esta uniformización por parte de los medios de comunicación, consigue que las audiencias perciban el entorno como algo único, homogéneo, como si no tuviera aristas. 


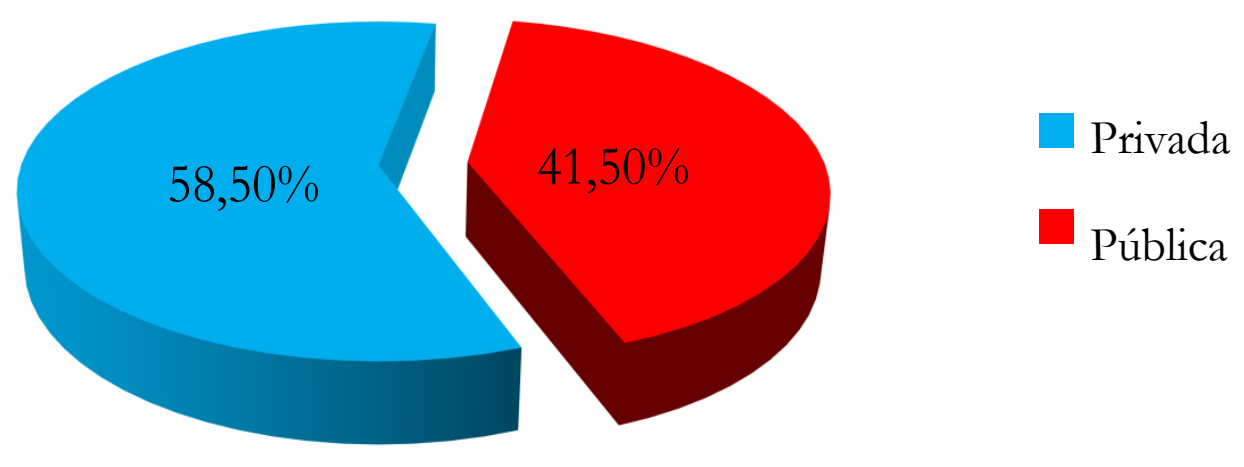

Gráfico 2: Distribución por tipo de gestión. Fuente: elaboración propia

La gran mayoría de las piezas informativas analizadas, dos de cada tres, cuentan con tres o más eventos noticiables en su estructura. Podemos ejemplificar lo anterior diciendo que un mismo hecho registrado en una zona geográfica ha tenido diferentes impactos o perturbaciones (eventos): inundación de calles, cortes de luz, carreteras cortadas, desvío del tráfico aéreo, cierre de escuelas, etcétera. El hecho de que haya muchos eventos en cada pieza informativa significa que, aunque los periodistas centren su interés en un determinado hecho, suelen enumerar los eventos encontrados en lugar de detenerse en lo sucedido, o en lo que pueda suceder, esto es, "explicando causas", "describiendo los eventos" y "evaluando consecuencias".

Lo más común es que se coloquen, en el espacio disponible, todas las afectaciones registradas sin un orden lógico secuencial. Lo anterior ocasiona que el espectador experimenta la confusión de los eventos, pero no es capaz de reordenarlos por su cuenta y, mucho menos tener la capacidad de aprender de ellos. Algo que debería de ocurrir.

Respecto a cuándo son emitidas las noticas que se han recogido para el estudio, más de la mitad aparecen en los telediarios del mediodía $55,6 \%$, un $37,3 \%$ en los de la noche y sólo un 7,1\% en los matinales. En este punto hay que decir que si llegase a suceder un acontecimiento de mayor impacto y trascendencia, los horarios y los 
estilos editoriales se ajustarían a los tiempos y espacios del hecho catastrófico. Ahora bien, como en el año analizado no sucedieron acontecimientos catastróficos que extendieran o ensancharan el interés informativo, se impuso el criterio editorial, y éste no es otro que situar las noticias más novedosas e importantes en el telediario del mediodía, horario tradicional para el consumo de información televisiva en España.

La duración de las noticias la podemos ver en el gráfico 3. Casi la mitad, un 46,5\% dura más de dos minutos, un 44,4\% entre un minuto $\mathrm{y}$ dos, un escaso $7,5 \%$ entre treinta segundos y un minuto, y un anecdótico 1,6\%, menos de treinta segundos. Estamos por lo tanto ante una serie de noticias largas, que se toman su tiempo para explicar los eventos sucedidos. En este punto, si cruzamos esta variable con la del canal de emisión, vemos como las piezas de mayor duración corresponden a TVE. Algo lógico si tenemos en cuenta que es el telediario de mayor duración de los tres, y que cuenta con una responsabilidad de servicio público intrínseca.

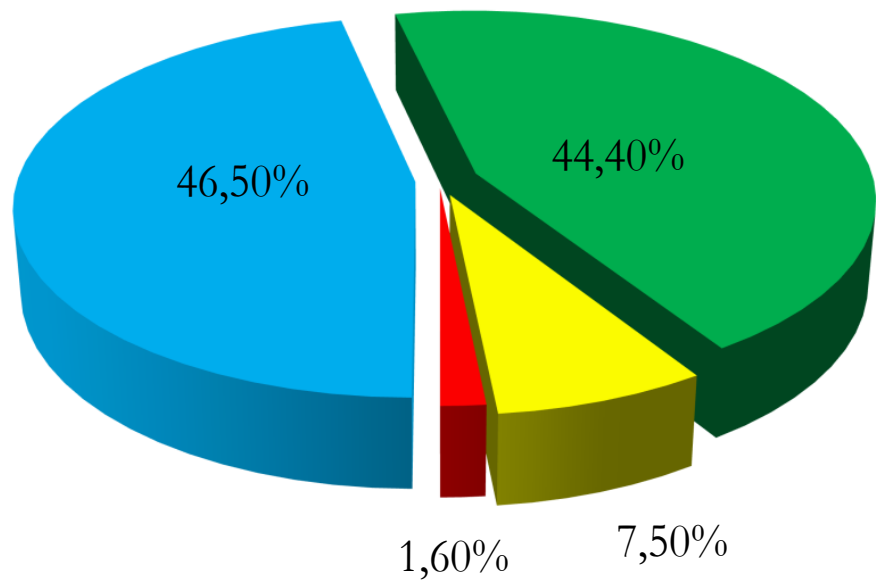

más de 120 s

de 60-120s de 30$60 \mathrm{~s}$

menos de 30s

Gráfico 3: Distribución por escenario de afectación. Fuente: elaboración propia

Resumiendo, nueve de cada diez de las piezas recogidas duran más de un minuto, algo verdaderamente reseñable para cualquier telediario, donde el tiempo de la escaleta está medido al segundo. Las noticias relacionadas ocupan por lo tanto, un importante lugar dentro de la cadena de valor de los telediarios españoles. 
Aunque los telediarios dediquen mucho tiempo y espacio a las noticias catastróficas, no significa que los eventos se expliquen mejor, todo lo contrario, se aprovecha el espacio y el tiempo (producción, conexiones en directo, etc.) para sumar y añadir más eventos catastróficos, y crear sensación de que se informa por acumulación de datos y no por lo que debería ser, por ordenamiento y secuencialidad de los mismos. Un editor de telediarios, en su defensa, podría justificarse argumentando que existen programas dedicados a la meteorología donde hay más tiempo y espacio para tratar con detalle, explicar, e intentar formar a las audiencias ante esta clase de eventualidades. En tal caso, hay que decir que tales justificaciones no avalan la falta de precisión y ordenamiento de las piezas informativas de los telediarios cuando hablan de los eventos catastróficos.

Es evidente que en cualquier telediario los reportajes acaparan informaciones relevantes que describen el acontecimiento (Sánchez Calero, M ${ }^{a}$ L; Morales, E. y Cáceres, $M^{a}$ D, 2012). Sin embargo, sólo el 1,8\% de los eventos fueron recogidos en forma de reportaje, siendo el género más utilizado el de noticia, con un aplastante $98,2 \%$.

Si hacemos referencia a los escenarios de afectación de los eventos noticiables, vemos en el gráfico 4 cómo están distribuidos. Cuando hablamos del espacio público nos referimos concretamente a que las afectaciones o trastornos se materializan, sobre todo, en infraestructuras, inmuebles y transportes públicos, aunque también habría que hablar de zonas agrarias, de ecosistemas protegidos y de espacios genéricos, no especificados en el discurso, pero que implícitamente alcanzan a todos. Los siguientes escenarios importantes de afectación están relacionados con los espacios privados (inmuebles y transportes). En ocasiones es difícil establecer claramente entre el espacio público y privado por lo que las afectaciones son múltiples (público + privado). 


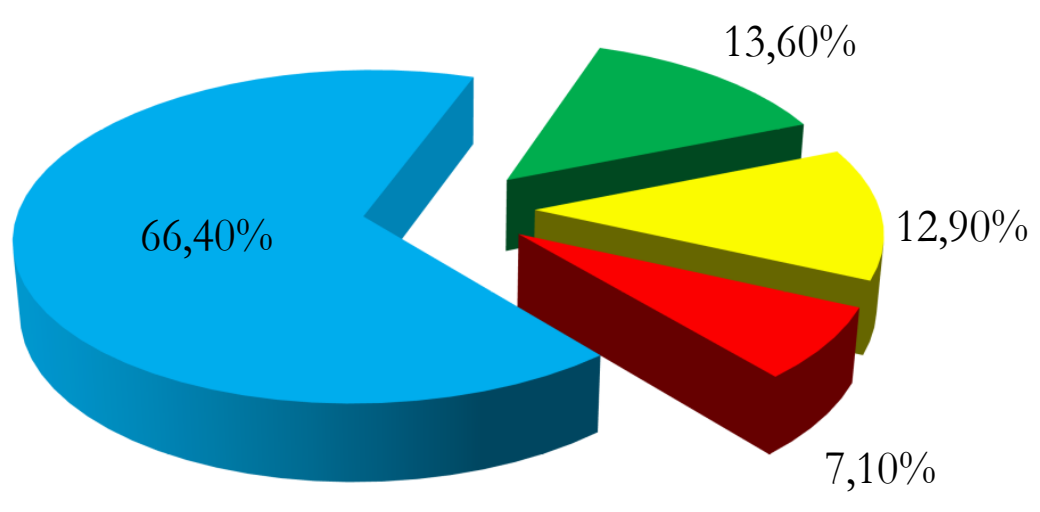

Público

Público + privado

Privado

Personal

Gráfico 4: Distribución por escenario de afectación. Fuente: elaboración propia

En cuanto a las zonas de afectación de los eventos de las piezas, el Norte de España representa un 40\% del total, la zona del Mediterráneo un 23\%, la zona Centro un 21\% y un sorprendente $10 \%$ en Canarias, quedando sólo un 3,5\% para dos o más zonas y un $1,1 \% \mathrm{NP} / \mathrm{NC}$.

En este punto se cumple la tónica y creencia general que en el Norte de España hace peor tiempo, y por lo tanto es más propensa a que se produzcan más eventos catastróficos de origen natural. Según el registro de los telediarios, Galicia se ha llevado la peor parte, convirtiéndose este invierno en la comunidad autónoma donde se han registrado una de cada cuatro perturbaciones, seguida muy de lejos por Canarias, País Vasco, Aragón, Cataluña, Andalucía y Comunidad Valenciana.

Debido a la situación extraordinaria vivida durante el invierno pasado, se puede afirmar que ha existido una relación entre las perturbaciones encadenadas en el Atlántico y la zona norte peninsular. Ahora bien, cuando se analizan las perturbaciones en solitario (sin registrar ningún encadenamiento) se puede apreciar que se reparten en las zonas geográficas del norte, del centro y del mediterráneo 


\subsection{Cualitativo}

En este apartado se comenta brevemente el análisis conceptual, en el que se establecen las relaciones entre códigos y transcripciones, así como sus vínculos con otros elementos estructurales de los grupos de discusión de los Expertos y de los Periodistas.

El análisis conceptual se establece en dos niveles:

-Un primer nivel refleja las relaciones de los códigos con las transcripciones, que va a ser el principal soporte del análisis conceptual.

-Un segundo nivel refleja los vínculos entre los propios códigos, porque el análisis del discurso proporciona una serie de relaciones que deben ser tomadas en consideración.

Ambos niveles se representan gráficamente, código a código (32 para el de Expertos y 17 para el de Periodistas), mostrando las diferentes relaciones con el discurso de los entrevistados (networks). Estos códigos se organizan en cuatro niveles que miden su importancia en el discurso. Es importante remarcar en este punto la relación directa y continua que los dos niveles de análisis van a tener entre sí, mezclando sus referencias y vínculos para conformar el corpus analizado.

\subsubsection{El discurso de los expertos, divulgadores y técnicos}

En el primer nivel se ven las relaciones de los códigos con las transcripciones y con las referencias discursivas de los participantes. Se muestra ya el inicio del análisis conceptual del discurso de los participantes en 32 códigos. La media de las referencias discursivas de éstos está en 6,7, eso significa que los códigos que estén por encima de este porcentaje tienen mayor peso en el discurso y, lo contrario, los códigos que estén por debajo de este cifra tienen menor carga. La primera valoración es que ocho códigos centrales destacan sobre los demás, son los que vertebran el discurso. Son aquellos que superan ampliamente la media, tomando 10 o más referencias discursivas. Este dato (cuantitativo) cimienta la técnica cualitativa, valorando los temas debatidos. 
En relación con la representación del número vínculos entre los códigos del grupo de expertos, el segundo nivel del análisis cualitativo, tiene que ver con los vínculos entre los propios códigos. La media de vínculos está en 7,6, eso significa que los códigos que estén por encima de este porcentaje tienen una mayor cohesión discursiva con el resto, mientras que los que estén por debajo lo contrario.

A continuación, en el gráfico 5, se muestra un ejemplo del network de una de las variables del grupo de expertos en el que se relacionan los dos niveles antes explicados. Este es sólo uno de los 18 que se han hecho para este grupo de discusión, y que no reproducimos todos por falta de espacio.

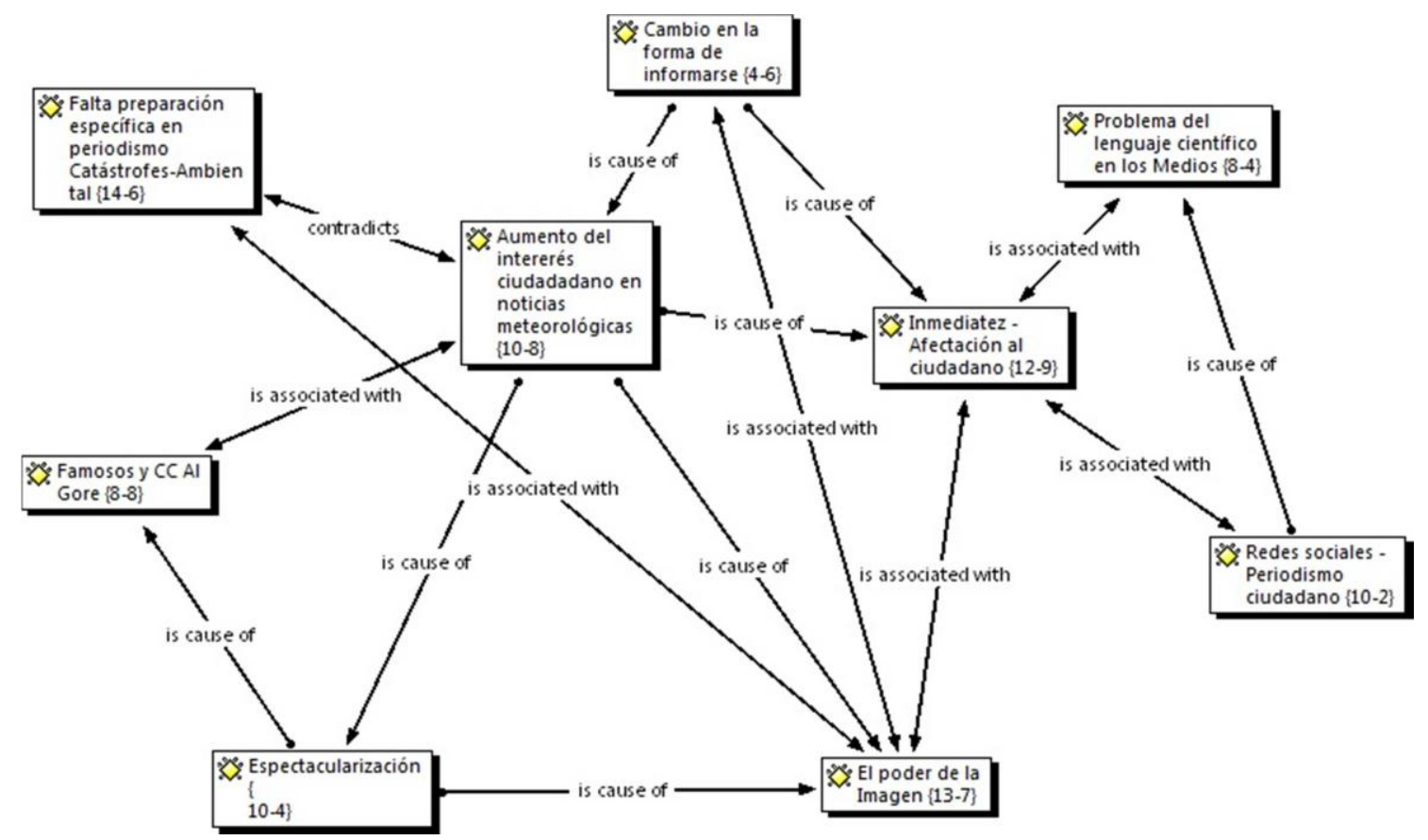

Gráfico 5: Ejemplo de network de la variable Aumento del interés ciudadano en noticias meteorológicas. Fuente: elaboración propia.

El grupo de discusión de los Expertos centra su discurso en la necesidad y en la oportunidad, que los medios de comunicación tienen de poder ser utilizados como mecanismos de prevención, en situaciones de catástrofes o de situaciones de riesgo. Los expertos destacan el gran poder de difusión, destacando los medios clásicos, como la televisión, pero haciendo también especial hincapié en las redes sociales y los nuevos medios basados en Internet. Su difusión 
masiva e instantánea son dos de sus principales características, que no se deben dejar pasar por alto, porque se pueden salvar vidas gracias a una acertada difusión de conceptos muy básicos.

Destaca también la gran relación que existe entre las noticias de catástrofes y la creación de un espectáculo en torno a ella. Sobre todo si hablamos de televisión o de imagen gráfica. Hablan incluso de una tiranía de la imagen que puede tener efectos negativos sobre una correcta cobertura mediática del fenómeno. Alertan también de que se deben abordar las informaciones con personal lo suficientemente cualificado como para no correr el riesgo de cometer errores fatales, que puedan desencadenar tragedias o situaciones no deseadas. El poder de los medios de comunicación es inmenso, y una mala recomendación o una información no confirmada, pueden dar lugar a desalojos no aconsejados por los equipos de protección civil. De hecho, comentaron un caso concreto en el que sucedió una tragedia por un consejo de evacuación muy desafortunado, que terminó en varias muertes en EE. UU.

Es importante remarcar también las propuestas que los expertos han volcado en su discurso, para mejorar la comunicación de catástrofes, destacando sobre todas ellas la mejora en la formación de los profesionales implicados, y la creación de una agencia que pueda centralizar toda la información de una manera eficaz y coordinada entre expertos, autoridades y mecanismos de salvamento.

Para los expertos, la pérdida del interés de los medios en noticias de catástrofes sucede por varios motivos: el principal es la grave situación económica que hace cada vez más difícil cubrir correctamente este tipo de noticias con medios propios. Se adopta por utilizar con una mayor frecuencia medios locales, que abaratan el coste total de la cobertura. Esto, a juicio de los expertos, empeora la calidad de la información, debido a un intercambio de reporteros no cualificados en noticias de esta índole.

Por último, se destaca cómo la catástrofe arrastra el tema del Cambio Climático a ser noticiable. En cuanto hay un efecto climático grave se pregunta a los expertos si tiene relación con el Cambio Climático. Es un recurso fácil que muchas redacciones no dudan en utilizar. 


\subsubsection{E1 discurso de los periodistas especializados}

En este apartado vamos a analizar con los periodistas los mismos aspectos que ya realizamos con los expertos. La mayoría de los temas hacen referencia a la visión personal de los participantes de los grupos de discusión sobre la temática de las situaciones de riesgo y catástrofes, que son los que vertebran la estructura del análisis. Se muestra ya el inicio del análisis conceptual del discurso de los participantes a partir de 17 códigos del discurso. La media de las referencias discursivas de éstos está en 3,8. Eso significa que los códigos que estén por encima de este número tienen un mayor peso en el discurso y, lo contrario, los códigos que estén por debajo de esta cifra tienen menor carga.

La primera valoración es que seis códigos centrales destacan sobre los demás, son los que vertebran el discurso. Son aquellos que superan ampliamente la media, tomando 4 o más referencias discursivas. Este dato (cuantitativo) cimienta la técnica cualitativa, valorando los temas debatidos. En el segundo nivel de vínculos encontramos diecisiete códigos con su número de relaciones entre ellos, mostrando la referencia al discurso que conforma con las claves del texto. La media de vínculos está en 4 entre las categorías que tienen referencias directas sobre la transcripción.

El grupo de discusión de los periodistas presenta tres códigos nuevos respecto al de los expertos que permiten una mayor personalización en su discurso, debido a que son parte implicada en el proceso a estudiar. Los códigos exclusivos son: concepto de riesgo, respuesta a los riesgos y vulnerabilidad vs amenaza $=$ riesgo.

El primero hace referencia al debate surgido en el grupo sobre la definición de riesgo, que enriqueció la calidad de las opiniones vertidas a continuación, al aclarar mucho más el tema. El segundo, respuesta a los riesgos, se ocupa de optimizar las respuestas que desde los medios de comunicación y desde las instituciones de salvamento se realizan en torno a su control. Y el último muestra la definición de afectación de la amenaza que uno de los miembros del grupo define a la perfección, mostrando que para que haya vulnerabilidad tiene que haber catástrofe con afectación humana o material, y no sólo catástrofe. 
El discurso ha girado sobre todo hacia las buenas prácticas que se deben realizar en el periodismo de catástrofes. Durante la técnica se han puesto varios ejemplos de buenas y malas praxis amparadas por las vivencias de los protagonistas. Los resultados han sido enriquecedores, aportando verosimilitud al conjunto.

Los periodistas opinan que existe una excesiva necesidad de crear espectáculos en torno a las noticias de catástrofes, sobre todo algunos medios. Necesitan mostrar en toda su crudeza las imágenes con las que impactar a sus espectadores. En este punto coinciden con los expertos al colocar el foco en las redacciones como fuentes del proceso de espectacularización de las noticias, centrándose en el poder de la imagen como reclamo periodístico. El debate es evidente, porque se produce una crítica ante la falta de rigor objetivo de muchos de los medios españoles.

Otro tema importante es el uso adecuado de los términos científicos en las noticias. Los periodistas reclaman una mayor formación para poder explicarlos con mayor claridad a la audiencia. Necesitan de una relación más fluida con los expertos e investigadores, o de un intermediario, porque la mayoría de las veces no entienden la terminología específica. Apuestan también por ir introduciendo, poco a poco, terminología avanzada para captar la atención del público y conseguir que lleguen sus mensajes, sobre todo en situaciones de alerta o de complicaciones graves que pueden acarrear situaciones de riesgo para la población.

Por último se consensuan una serie de soluciones de cambio de modelo de vida y comunicativo sobre el Cambio Climático, como medida ejemplar de manifiesto mediático. Es un ejercicio importante que los propios periodistas sean conscientes y muestren autocrítica hacia una mayor responsabilidad en sus informaciones, y muestren intención de mejorar la calidad de las mismas.

\section{Conclusiones}

La primera conclusión, es que según el estudio presentado, las noticias de riesgos y catástrofes naturales emitidas por los telediarios españoles seleccionados no presentan grandes diferencias. Es decir, se produce una uniformidad informativa (formato y contenido), a la 
hora de abordar este tipo de noticias. A priori, sería lógico pensar que una cadena pública como TVE, dedicaría más tiempo y contenido a este tipo de noticias, por su talante de servicio, y, aunque así se produce, no es demasiado significativo, siendo la construcción y el tratamiento de los eventos muy parecidos respecto al resto de cadenas analizadas.

La duración de las noticias relacionadas es larga o muy larga. Esto demuestra la importancia que tiene en las escaletas de los canales seleccionados. Pero de nada sirve dedicar mucho tiempo a una noticia si no se aborda correctamente, aportando diferentes puntos de vista y contrastarlo con la información "oficial".

Además, la construcción del relato de los eventos adquiere una estructura particular, que es repetida por todas las cadenas. Se apuesta siempre por una repetición de afectaciones cuando se produce un riesgo o catástrofe, como si esa acción hiciese más completa la noticia, cuando, generalmente, se evita un tratamiento informativo desde todos los puntos de vista implicados, intentando ofrecer la tan ansiada objetividad.

Respecto al tipo de afectación catastrófica que suelen mostrar las noticias de las cadenas analizadas, un gran porcentaje muestra cómo los medios ofrecen una mayor procedencia pública a la hora de mostrar la localización de los eventos, frente a afectaciones de tipo privadas o mixtas (públicas más privadas). Es lógico pensar que aquello que afecta a todos tiene un mayor peso periodístico o noticiable.

Las audiencias suelen conseguir más confusión que información en noticias de riesgos o catástrofes de origen natural. No existen protocolos claros y uniformes de cómo actuar, dejando improvisar los medios. Aquellos periodistas experimentados y formados podrán ofrecer la información de manera correcta, pero aquellos que no lo estén, cometerán errores, con posibles consecuencias no deseadas. Se produce un problema por lo tanto de posicionamiento, encuadre o framing ante este tipo de coberturas.

Los expertos argumentan que no se suele recurrir a ellos como fuentes de información especializada. Se pierde así una importante 
colaboración para ofrecer buena información de fuentes fidedignas. Además, explican, que se suelen mostrar imágenes espectaculares, que impacten a la audiencia, en lugar de cubrir correctamente el evento, que buscan el impacto en la audiencia, alimentando su morbosidad. Destacan también el gran poder que tienen en la actualidad los medios, y se lamentan de las oportunidades perdidas que se han producido para informar educando a la ciudadanía. Defienden que los medios cubren generalmente mal las noticias de riesgos y de catástrofes naturales. Argumentan varias causas, pero la fundamental es la grave crisis económica actual, que provoca que recurran a medios locales inexpertos en este tipo de eventos, en lugar de periodistas experimentados.

Los periodistas especializados argumentan, en la línea de los expertos, que los medios suelen tender a la espectacularización al cubrir noticias de este tipo, donde la imagen siempre prima sobre la información. Argumentan que no suele haber un uso adecuado de los términos científicos en las noticias, por falta de formación específica, y reclaman una mejor comunicación entre expertos e investigadores, con el fin de usar correctamente la terminología específica.

En definitiva, ambos colectivos coinciden que aún hay mucho por hacer en este tipo de cobertura mediática. La audiencia también tiene su parte de culpa, al ver uno u otro informativo y debe exigir, como receptor, una mejor información, con la que cumplir sus objetivos. Todos los actores implicados deberán mejorar sus acciones para construir un mejor modelo comunicativo de este tipo de eventos en España.

\section{Bibliografía}

Alonso, L. E. (1998) La mirada cualitativa en sociología. Ed. Fundamentos

Gaitán, J. A. y Piñuel, J. L. (1995). Metodología general: conocimiento cientifico e investigación en la comunicación social. Madrid. Síntesis, $639 \mathrm{pp}$.

Gaitán, J. A. y Piñuel, J. L. (1998) Técnicas de investigación en comunicación social. Ed. Síntesis 
Hansen, A. (2011). Environment, Media and Communication. Nueva York. Routledge.

Ibáñez, J (1979) Más allá de la sociología. El grupo de discusión: técnica y crítica. Ed. Siglo XXI

Lozano, C (2009) "El medio ambiente como una referencia dominante en la construcción social del acontecer catastrófico" en Carabaza, J. y Lozano, J. C. (Eds.) Comunicación y Medio Ambiente. Reflexiones, análisis y propuestas. Monterrey, México, Instituto Tecnológico y de Estudios Superiores de Monterrey. 132-159.

Major, Ann M. y Atwood, L. Erwin (2004): "Environmental risks in the news: issues, sources, problems and values". Public Understanding of Science, vol. 13, $\mathrm{n}^{\mathrm{o}} 3$. Thousand Oaks, Sage, pp. 295-308.

McCombs, M. (2005): “A look at agenda-setting: Past, present and future”. Journalism Studies, vol. 6, $\mathrm{n}^{\circ}$ 4. Oxford, Taylor and Francis Group, pp. 543-557.

Sánchez Calero, M $M^{a}$ L; Morales, E. y Cáceres, $M^{a}$ D (2012) "La cobertura televisiva de la Cumbre de Cancún: agenda temática, discursos y fuentes en los informativos españoles" Index Comunicación: No 2 - 2012 Madrid, España. 113128 pp.

Piñuel, J. L., Gaitán, J. A. y Lozano C. (2013). Confiar en la prensa o no. Un método para el estudio de la construcción mediática de la realidad. Salamanca, Ed. Comunicación Social, 206 pp. 


\title{
Las catástrofes en las revistas semanales brasileñas: evidencias y silenciamientos*
}

\author{
Márcia Franz Amaral - Universidade Federal de Santa María (Brasil) \\ marciafranz.amaral@gmail.com
}

Resumen: A pesquisa analisa os sentidos das catástrofes que envolvem o meio ambiente nas principais revistas brasileiras: Veja, Isto É, Época e Carta Capital. As revistas tiveram, em 2013, a circulação de quase um milhão e oitocentos mil exemplares semanais. Foram analisadas 41 matérias sobre tragédias que envolveram a natureza no período de três anos (2011 a 2013). Utilizamos aportes metodológicos da Análise de Discurso de linha Francesa. Coletamos 675 sequências discursivas que mencionam especificamente as causas, a força e frequência das tragédias e as reunimos em oito Famílias Parafrásticas. A partir de ampla revisão de literatura sobre os discursos sobre o ambiente (Dryzek, 2005), as catástrofes (Lozano Ascêncio, 2004), os desastres (Gilbert, 1995), os públicos envolvidos (Valêncio, 2010) e as concepções de risco (Smith, 1992), reunimos as Famílias Parafrásticas em três Formações Discursivas: Afogados no descaso (60,86\% das ocorrências), Fúria da natureza $(34,36 \%$ das ocorrências) e Fomos nós quem fizemos a chuva (4,74\% das ocorrências). O trabalho conclui que as revistas priorizam um discurso reformista, de cunho racional administrativo sobre as catástrofes, porém, há uma responsabilidade "flutuante" atribuída aos diversos agentes sociais. Destacam-se discursos que evidenciam a vulnerabilidade social, mas escondem as desigualdades sociais. Há o silenciamento de 
manifestações reformistas, sustentáveis ou de necessidade de mudanças radicais sobre o ambiente. De maneira geral, predomina uma concepção comportamental sobre o risco, que não leva em consideração as questões estruturais e restringe o acontecer catastrófico.

Palabras clave: Discurso jornalístico; Jornalismo de revista; cobertura de catástrofes; jornalismo ambiental

\section{Introdução}

$\mathrm{D}$ ESASTRES e catástrofes integram os relatos humanos desde sempre, mas a forma como os construímos simbolicamente se modifica ao longo do tempo. Para Lozano Ascêncio (2001), a ideia que se tem das catástrofes se determina segundo as épocas históricas e as épocas históricas também evidenciam pelas ideias que se tem das catástrofes. Em cada período histórico, há uma delimitação conceitual do acontecer catastrófico. No caso das catástrofes que envolvem o ambiente, nelas estão imbricadas também concepções sobre a relação homem- natureza. Por isso, as catástrofes que envolvem a natureza tem mais a ver com a cultura do que com o próprio meio ambiente.

Nestrovski e Seligmann-Silva (2000) explicam que a palavra catástrofe vem do grego e significa "virada para baixo" (kata + strophé). Catástrofes e desastres são termos que se diferenciam pelas suas dimensões. Embora instituições brasileiras como o Instituto Nacional de Pesquisas Espaciais (INPE) e Defesa Civil detalhem as diferenças entre eles, para fins deste trabalho vamos considera-los sinônimos, pois nos interessam mais as questões sociais e culturais que envolvem este tipo de evento.

O pensamento científico foi modificando sua compreensão das catástrofes e desastres que envolvem a natureza ao longo da nossa história recente. Conforme López (1999), a maior parte das primeiras pesquisas sobre os desastres enfatizavam seus agentes físicos, as medidas para evitá-los e o manejo da população afetada. Dos anos 1950 a 1970, a ênfase das pesquisas era o comportamento dos indivíduos e das organizações. Os padrões socioculturais e o contexto histórico da sociedade raramente faziam parte da análise. No início 
dos anos 1980, com o desenvolvimento de perspectivas como a Geografia Cultural e a Ecologia Cultural, os desastres foram redefinidos em função também das estruturas sociais. As perspectivas culturais, explica López (1999), propõem que os desastres não se sucedem simplesmente, mas são consequência de forças sociais, políticas e econômicas. As catástrofes são resultados tanto de processos que se desenvolvem durante largos períodos de tempo como de crises repentinas.

Desde o início dos anos 1990, o conceito de vulnerabilidade se desenvolve como alternativa ou complemento ao paradigma de riscos. Diz López (1999) que o paradigma de riscos presta mais atenção ao evento em si e promove os sistemas de prevenção. $\mathrm{O}$ da vulnerabilidade se centra em que são os afetados e sua capacidade de resistir. Ressalta a importância da ordem socioeconômica e das relações ecológicas. Mas como a cobertura jornalística tem tratado do tema? Em que paradigmas tem se assentado? Tem acompanhado a discussão realizada pela Sociologia e pela Antropologia?

Partimos do pressuposto que sem comunicação não há catástrofe (Lozano Ascêncio, 2004). O acontecer catastrófico é uma modalidade do acontecimento público que monopoliza a atenção:

"las catástrofes no siempre son imprescindibles para que exista su relato, pero éste sí es ineludible para que existan catástrofes; em consecuencia, el momento más importante (em tanto que comprensible y significativo) de las catástrofes no es aquel em el que se leevan a cabo, sino aquel em el que se relatan [...]." (Lozano Ascêncio, 2009: 3)

Por isso, uma catástrofe afeta hoje muito mais que suas antecessoras mais conhecidas (Lozano Ascêncio, 2005). Se em anos passados as catástrofes eram problemas "dos outros" e suas vítimas eram reduzidas apenas a números, hoje as catástrofes são de todos (Serra, 2006), todos nos tornamos vítimas virtuais.

Como afirma Lozano Ascêncio, "la principal puerta de acceso a los médios de comunicación para el médio ambiente sigue siendo el desastre, la cruda imagen que garantisse el impacto del público". (2004: 33) 
Nossa pesquisa busca os sentidos das catástrofes que envolvem o ambiente nas revistas semanais brasileiras referentes as suas causas, força e frequência. A cobertura do tema assume tons diferentes em cada uma das revistas semanais, o que justifica a escolha de quatro revistas para o estudo: Veja, IstoÉ, Época e Carta Capital. As revistas analisadas somam, em circulação em 2013, quase um milhão e oitocentos mil de exemplares semanais (Associação Nacional...,2014). Veja está em primeiro lugar, com 1.43.147 exemplares, Época está em segundo, com 387.956, IstoÉ em quarto com 332.813 e Carta Capital está em vigésimo lugar com 30.561 exemplares. Foram analisadas 41 matérias das quatro revistas.

\section{Os discursos jornalísticos sobre catástrofes e desastres}

Consideramos que as catástrofes ambientais trazem excelentes condições para examinarmos a cobertura jornalística. As catástrofes expõem nossa estrutura social e cultural mais bruscamente do que outros importantes eventos. (Clarke, 2005 apud Perrow, 2007). A maneira como o jornalismo cobre os desastres nos tempos de crise gera um esquema narrativo para o leitor que acaba se mantendo também em outros períodos. Os relatos de catástrofes se convertem em poderosas chaves narrrativas (Lozano Ascêncio, 2013) para a compreensão do ambiente, das mudanças climáticas, das vulnerabilidades sociais e dos riscos.

Para Molocht e Lester (1993: 47), este processo de disrupção acidental, seguido de tentativas para restaurar os significados tradicionais, faz com que os acidentes se constituam em um "recurso crucial para o estudo empírico dos processos de estruturação de acontecimentos".

O campo jornalístico, no caso da cobertura de catástrofes, assenta-se nos campos científicos e políticos para esquadrinhar os riscos que envolvem a natureza, explicá-los e construir sistemas de prevenção. A cobertura que inicialmente se restringia a contar mortos e feridos hoje envolve a busca da compreensão do acontecimento com a manifestação dos experts, a cobrança pela ação dos homens públicos e o relato pormenorizado das testemunhas. A cobertura das catástrofes está presidida pela tendência ao catastrofismo e ao sensacionalismo, pela preponderância da imagem sobre a análise, pela 
personalização das vítimas e despersonalização na hora da depuração das responsabilidades. As questões ambientais são referenciadas muitas vezes de maneira redutora e a estrutura social que viabiliza as catástrofes costuma ficar silenciada, enquanto aspectos gerenciais são utilizados como chave explicativa.

\section{Questões metodológicas}

Analisamos os sentidos das catástrofes em todas as matérias encontradas sobre o tema, num total de 41 matérias, sendo 14 matérias da revista Veja, 17 matérias da revista Época, 6 matérias da revista Isto É e 4 da revista Carta Capital. Destacamos durante a análise o total de 675 Sequências Discursivas (SDs) que remetem diretamente aos motivos, força e frequência das tragédias. Neste período, houve catástrofes significativas tais como os deslizamentos na região serrana do Rio de Janeiro, o terremoto e tsunami no Japão e o tufão nas Filipinas. Algumas matérias que integram o corpus também repercutiram tragédias ocorridas em outros períodos, como é o caso do terremoto no Haiti.

Baseamo-nos em alguns fundamentos da Análise do Discurso, principalmente em Orlandi (1996), para quem a análise tem como momentos primeiramente a apreensão das paráfrases, ou seja, o inserir dos dizeres no domínio da paráfrase, estabelecendo a relação do dizer com outros dizeres. As paráfrases são relações de sentido que se dão no interior de determinada Formação Discursiva, englobam o processo de efeitos de sentidos que se produz no interdiscurso, envolvem um retorno ao já-dito.

Agrupamos os enunciados primeiramente em Famílias Parafrásticas. Mapeamos regularidades, tais como ordens, correlações, funcionamentos, premissas, expressões que constroem o caminho em direção ao um sentido nuclear. Elegemos, a seguir, os enunciadossínteses, ou seja, nomeamos cada uma das Famílias Parafrásticas.

Posteriormente, agrupamos as Famílias Parafrásticas (FP) de forma a relacioná-las em Formações Discursivas (FD). Embora a noção de Formação Discursiva seja instável, a utilizamos para caracterizar um mesmo sistema de regras que determinam o que pode e deve ser dito, a partir de uma posição dada em uma conjuntura dada. 
O primado do interdiscurso faz com que percebamos as Formações Discursivas de forma relacional. Como diz Orlandi, são "regionalizações do interdiscurso, configurações específicas dos discursos em suas relações" (2002: 43). As Formações Discursivas, portanto, não são homogêneas e suas fronteiras são fluidas. Para Pêcheux, a Formação Discursiva não é um espaço estrutural fechado, pois ela é constitutivamente invadida por elementos provenientes de outros lugares. Diz o autor que, "o próprio de toda FD é dissimular, na transparência do sentido que aí se forma (...) o fato de que isso 'fala' sempre, antes, fora, ou independentemente (...)", ou seja, são constitutivamente heterogêneas (1988: 147).

"A AD contribui para pensar o discurso jornalístico como formador de redes interdiscursivas, por meio de retomadas, réplicas, atualizações e deslocamentos de outros tantos jáditos, de dizeres oriundos de campos diversos. O discurso abriga sempre uma série de outros discursos, é atravessado e constituído por eles, mesmo que estes se submetam a regras que não eram próprias de sua origem." (SCHWAAB e ZAMIN, 2014:.53)

Finalmente, para além de sistematizar regularidades e identificar paráfrases no interior das matérias jornalísticas, num segundo momento buscamos refletir sobre como estas Formações Discursivas se alimentam de determinadas Formações Ideológicas. Assim, refletimos sobre estas Formações Discursivas em relação a concepções sobre o ambiente, ao desastre, ao risco e ao discurso do Estado sobre comportamento dos envolvidos.

\section{Análise}

As Sequências Discursivas que remetiam às causas, força e frequência dos desastres foram destacadas das revistas e reunidas em oito Famílias Parafrásticas nomeadas por enunciados-síntese que evidenciam seus sentidos.

Quadro I - Resumo dos Enunciados- síntese e de suas Sequências Discursivas (SDs) 


\begin{tabular}{|c|c|c|c|}
\hline $\begin{array}{l}\text { Enunciados-síntese das } \\
\text { Famílias Parafrásticas }\end{array}$ & $\begin{array}{l}\text { Percer } \\
\text { SDs }\end{array}$ & ual de & $\begin{array}{l}\text { Percentual de SDs/ } \\
\text { total de ocorrências de cada } \\
\text { FP }\end{array}$ \\
\hline & Veja & $50 \%$ & \\
\hline & Época & $31,86 \%$ & $31,11 \%$ \\
\hline A fúria incontrolável & IstoÉ & $32,62 \%$ & Total: 210 ocorrências \\
\hline & Carta & $14,95 \%$ & \\
\hline & Veja & $10,93 \%$ & \\
\hline & Época & $26,18 \%$ & $29,77 \%$ \\
\hline Omissão do Poder Público & IstoÉ & $30,48 \%$ & Total: 201 ocorrências \\
\hline & Carta & $50,46 \%$ & \\
\hline & Veja & $12,5 \%$ & \\
\hline & Época & $23,65 \%$ & $18,22 \%$ \\
\hline O desastre do planejamento & IstoÉ & $14,97 \%$ & Total: 123 ocorrências \\
\hline & Carta & $11,21 \%$ & \\
\hline & Veja & $7,81 \%$ & \\
\hline & Época & $4,41 \%$ & $6,51 \%$ \\
\hline Os mortos de janeiro & IstoÉ & $8,55 \%$ & Total: 44 ocorrências \\
\hline & Carta & $8,41 \%$ & \\
\hline & Veja & - & \\
\hline & Época & $7,57 \%$ & $5,03 \%$ \\
\hline Todo desastre $t$ causas & IstoÉ & $4,81 \%$ & Total: 34 ocorrências \\
\hline & Carta & $0,93 \%$ & \\
\hline & Veja & - & \\
\hline & Época & $3,47 \%$ & $4,74 \%$ \\
\hline Fomos nós quem fizemos a chuva & IstoÉ & $5,34 \%$ & Total: 32 ocorrências \\
\hline & Carta & $10,28 \%$ & \\
\hline & Veja & $4,68 \%$ & \\
\hline & Época & $2,83 \%$ & $3,25 \%$ \\
\hline Todos os anos a natureza mostra & IstoÉ & $3,20 \%$ & Total: 22 ocorrências \\
\hline sua força & Carta & $3,73 \%$ & \\
\hline & Veja & $14,06 \%$ & \\
\hline & Epoca & & $1,33 \%$ \\
\hline Banno de lama na Civiluzaģao & IstoE & - & Total: 9 ocorrências \\
\hline & Carta & & \\
\hline
\end{tabular}

Posteriormente, foram reunidas em Formações Discursivas. A primeira delas prioriza a omissão do Poder Público, a segunda reitera a violência da natureza e a frequência dos acontecimentos e a terceira região de sentidos atribui os desastres à falta de preservação ambiental pelo homem em geral. Caracterizamos as FDs 
respectivamente como predominante, complementar e residual por entender que elas não necessariamente concorrem entre si, mas se completam e se interpenetram.

Abaixo, explicamos cada uma das Famílias Parafrásticas, já localizadas nas Formações Discursivas que lhes dão abrigo.

\subsection{FD predominante: Afogados no descaso}

Esta Formação Discursiva é a predominante e é composta de cinco Famílias Parafrásticas que aparecem em 60,86\% das Sequências analisadas. Reúne sentidos que culpam diretamente o Poder Público pela falta de ação e de prevenção e mostram o quanto isso é rotineiro.

Quadro II - Famílias Parafrásticas que compõem a FD Afogados no descaso

\begin{tabular}{|c|c|c|c|c|}
\hline \begin{tabular}{|l|} 
FORMAÇÃO \\
DISCURSIVA
\end{tabular} & Enunciado-síntese/ & $\%$ & $\begin{array}{l}\text { Exemplo de Sequência } \\
\text { Discursiva }\end{array}$ & Total \\
\hline \multirow{5}{*}{$\begin{array}{l}\text { Afogados no } \\
\text { descaso }\end{array}$} & $\begin{array}{l}\text { Omissão Público } \\
\text { do } \\
\text { Poder }\end{array}$ & $29,77 \%$ & $\begin{array}{l}\text { "O que impede as } \\
\text { autoridades de retirar os } \\
\text { moradores de locais } \\
\text { perigosos?" (Época, } \\
\text { 25/03/2013, p.40) }\end{array}$ & \multirow{5}{*}{$60,86 \%$} \\
\hline & O desastre planejamento do & $18,22 \%$ & $\begin{array}{l}\text { “Quando falhamos em nos } \\
\text { preparar, nos preparamos } \\
\text { para falhar” (Época, } \\
18 / 11 / 2013 \text {, p. } 78 \text { ) }\end{array}$ & \\
\hline & Todo desastre tem várias causas & $5,03 \%$ & $\begin{array}{l}\text { "Há quem diga que a } \\
\text { confluência de condições } \\
\text { que criou esse monstro nada } \\
\text { mais é que uma infeliz } \\
\text { coincidência" (IstoÉ, } \\
\text { 14/11/2013, p.18) }\end{array}$ & \\
\hline & Os mortos de janeiro & $6,51 \%$ & $\begin{array}{l}\text { "A história se repete". (Carta } \\
\text { Capital, 26/01/2011, p.18) }\end{array}$ & \\
\hline & $\begin{array}{l}\text { Banho d Civilização } \\
\text { E lama na }\end{array}$ & $1,33 \%$ & $\begin{array}{l}\text { “A civilização vulnerável e } \\
\text { frágil perante a violência da } \\
\text { natureza." (Veja, } \\
\text { 16/03/2011, p.83) }\end{array}$ & \\
\hline
\end{tabular}


O enunciado síntese Omissão do Poder Público reúne Sequências Discursivas que evidenciam diretamente que a causa das catástrofes é a incompetência do Poder Público. Mencionam o Poder Público ou a agentes governamentais em geral, tais como governos e prefeituras, bem como menções a irregularidades, negligências, desvio de verbas, excesso de burocracias, promessas políticas, falhas gerenciais, atrasos de obras e falta recursos. Algumas SDs questionam a culpa dos fenômenos naturais pelo desastre, embora a questão da prevenção não seja citada diretamente.

As $\mathrm{SDs}$ reunidas sob o nome $\mathrm{O}$ desastre do planejamento explicam que a causa da tragédia é a falta de prevenção. Abordam diretamente a questão da prevenção, da necessidade de alertas e de equipamentos. O enunciado Todo desastre tem várias causas reúne SDs com um tom mais complexo em que as causas das catástrofes são difusas e multifatoriais. Aqui estão as SDs que afirmam as múltiplas causas das catástrofes ou duvidam que se possa atribui- las somente ao aquecimento global ou ainda relativizam culpas ou falam de maneira muito genérica das causas como "ocupação de planícies". Mencionam, por exemplo, responsabilidades compartilhadas, evidenciam a complexidade dos problemas. A Família Parafrástica cujo enunciado é Os mortos de janeiro mostra que a tragédia é rotina, evidencia a sua repetição e recorrência com ênfase na falta de prevenção. As SDs sob o nome Banho de lama na Civilização destaca que a causa das tragédias está ligada à fragilidade da civilização. Abriga SDs em que a catástrofe é remetida para um âmbito mais amplo que a relaciona com a as conquistas e fragilidades da civilização. O descaso, de maneira geral, refere-se à ineficiência gerencial do Estado e à falta de dispositivos imediatos de prevenção. Há uma cobrança grande das revistas quanto ao preparo dos governos, denúncias de irregularidades e de gastos inadequados do dinheiro público, bem como preocupação com a ocupação inadequada do solo.

\subsection{FD complementar: A fúria da natureza}

Trata-se da Formação que reúne 34,36\% das ocorrências e é integrada por dois enunciados-sintese. 
Quadro III - Famílias parafrásticas que compõem a Formação Discurso A fúria da natureza

\begin{tabular}{|c|c|c|c|c|}
\hline $\begin{array}{l}\text { Formação } \\
\text { Discursiva }\end{array}$ & $\begin{array}{l}\text { Família } \\
\text { Parafrástica/Enunciado- } \\
\text { síntese }\end{array}$ & $\%$ & $\begin{array}{l}\text { Exemplo de } \\
\text { Sequência } \\
\text { Discursiva }\end{array}$ & Total \\
\hline \multirow[t]{2}{*}{$\begin{array}{l}\text { A fúria da } \\
\text { natureza }\end{array}$} & A força incontrolável da natureza é & $31,11 \%$ & $\begin{array}{l}\text { "As chuvas fortes (e } \\
\text { devastadoras) de } \\
\text { verão não vão deixar } \\
\text { de acontecer." } \\
\text { (Época, 17/01/2011, } \\
\text { p. 41) }\end{array}$ & \multirow[t]{2}{*}{$34,36 \%$} \\
\hline & $\begin{array}{l}\text { Todos os anos a mostra sua força } \\
\text { natureza }\end{array}$ & $3,25 \%$ & $\begin{array}{l}\text { "A cada ano, São } \\
\text { Paulo é inundada } \\
\text { pelas chuvas de } \\
\text { verão." (IstoÉ, } \\
\text { 19/01.2011, p.52) }\end{array}$ & \\
\hline
\end{tabular}

O enunciado-síntese A força da natureza é incontrolável mostra que a causa das catástrofes é a violência da natureza. Abriga sequências em que os sujeitos da ação são os fenômenos naturais. Diz respeito ao poder destrutivo da natureza, segundo Lozano Ascêncio (2005) um dos primeiros esquemas narrativos do acontecer catastrófico. Tem importância devido às evidências de aumento de eventos extremos envolvendo o ambiente. Além disso, é de grande valor-notícia para o jornalismo. Sua importância é esperada, afinal, aparentemente, é o comportamento "inesperado" da natureza que dispara o acontecimento catastrófico. Inspirados em Bird e Dardenne (1999: 263), podemos afirmar que há o triunfo de uma fórmula de construção narrativa que inicia com esta FP.

Já o enunciado-síntese Todos os anos a natureza mostra sua força evidencia que o evento natural é rotina e reúne SDs que mostram como esses fenômenos se repetem e realçam que os eventos fazem parte do ciclo natural. Tem alguns pontos de contato o discurso gerencial descrito acima. Ambas trazem a ideia de que um agente externo causou a catástrofe e, por vezes, transmite uma visão de fatalidade. 


\subsection{FD residual: Fomos nós que fizemos a chuva}

A Formação Discursiva Fomos nós que fizemos a chuva constrói o sentido de que a culpa é do homem e do aquecimento global reúne SDs nas quais o homem "em geral" é direta ou indiretamente mencionado como culpado pela tragédia. Aparece em apenas 4,74\% das Sequências, o que demonstra que a questão ambiental é tratada fragilmente pela cobertura jornalística. A Família Parafrástica aborda o desrespeito do homem tanto no trato direto com a natureza, em situações mais concretas como as que envolvem as ocupações irregulares, como em situações de maior magnitude como é o caso do aquecimento global.

Quadro IV - Família Parafrástica que compõe a Formação Discursiva Fomos nós que fizemos a chuva

\begin{tabular}{|c|c|c|c|c|}
\hline $\begin{array}{l}\text { Formação } \\
\text { Discursiva }\end{array}$ & $\begin{array}{l}\text { Família Parafrástica/Enunciado } \\
\text { - síntese }\end{array}$ & $\%$ & $\begin{array}{l}\text { Exemplo de } \\
\text { Sequência } \\
\text { Discursiva }\end{array}$ & Total \\
\hline $\begin{array}{l}\text { Fomos nós } \\
\text { que fizemos } \\
\text { a chuva }\end{array}$ & Fomos nós que firemos a chuva & $4,74 \%$ & $\begin{array}{l}\text { "Não há como } \\
\text { responsabilizar a } \\
\text { natureza." (Carta } \\
\text { Capital, 10/01/2011, } \\
\text { p. 12) }\end{array}$ & $4,74 \%$ \\
\hline
\end{tabular}

\section{Como os desastres são construídos?}

$\mathrm{Na}$ segunda parte da análise, relacionamos as Formações Discursivas a algumas concepções sobre o ambiente, os desastres, os envolvidos nas tragédias e concepções sobre o risco. Assim, apresentamos alguns aportes teóricos de autores que construíram tipologias sobre o tema. Buscamos neles as Formações Ideológicas que amparam as Formações Discursivas circunscritas por nós.

As três Formações Discursivas identificadas pela nossa análise Afogados no descaso (60,86\% das ocorrências), Fúria da natureza (34,36\% das ocorrências) e Fomos nós quem fizemos a chuva (4,74\% das ocorrências) tem uma base ideológica comum em seus discursos sobre o ambiente, mas variam em relação aos discursos sobre os desastres e os riscos. 


\subsection{Discurso ambiental}

Sobre as diferentes perspectivas do discurso ambiental, baseamo-nos em Dryzek (2005) que sistematiza três grupos de discursos sobre meio ambiente: discursos reformistas, discursos de Sustentabilidade e discursos Radicais.

Para o autor, os discursos Reformistas dividem-se em três tipos. Os de racionalidade administrativa são os que tornam o Estado e os peritos técnicos os principais agentes de resolução de problemas. A natureza fica subordinada à resolução de problemas humanos, as pessoas subordinadas ao Estado, especialistas e gestores no controle estatal. Os discursos de pragmatismo democrático acreditam na mobilização dos cidadãos e de grupos sociais e na sua influência sobre os processos de decisão política, crêem na igualdade entre os cidadãos. Envolvem muitos agentes e múltiplos interesses públicos. As politicas públicas são resultados de forças políticas. E os de racionalidade econômica priorizam as forças de mercado e do governo (e não dos cidadãos) na resposta a problemas ambientais.

Já os discursos de Sustentabilidade somam a proteção ambiental, o crescimento da economia e a justiça social e se preocupam com as gerações vindouras. Dividem-se em discursos de desenvolvimento sustentável que priorizam o crescimento econômico com proteção ambiental e são motivados pelo bem público e em discursos de modernização ecológica que acreditam que a política 'verde' e a tecnologia 'verde' podem gerar riqueza.

Os discursos de Mudanças radicais rejeitam a estrutura da sociedade industrial e baseiam-se no romantismo verde, que afirma que a consciência dos homens deve mudar e que deve haver um equilíbrio entre os homens e a natureza e na noção de racionalidade verde em que os problemas ambientais só serão resolvidos através de transformação estrutural. Veem a natureza como um sistema complexo, preveem igualdade entre as pessoas, envolvem muitos atores individuais e coletivos.

Quanto ao discurso sobre o ambiente, as três Formações Discursivas tem uma Formação ideológica comum, pois baseiam-se, conforme as classificações de Dryzek, no Reformismo e mais precisamente em 
uma concepção baseada numa Racionalidade Administrativa. Outras posições que envolvam a Sustentabilidade e Mudanças Radicais são silenciadas.

Baseados em Dryzek, destacamos o silenciamento de Sequências Discursivas Reformistas que acreditam na mobilização dos cidadãos e de grupos sociais e na sua influência sobre os processos de decisão política nos discursos que envolvem o ambiente. Aliás, apenas eventualmente aparecem pistas de que as politicas públicas são resultados de forças políticas. Aspectos ligados à junção das formas de mercado e de governo para responder a problemas ambientais também são raras. O discurso de Sustentabilidade que reúne proteção ambiental, o crescimento da economia e a justiça social e se preocupa com as gerações vindouras também não está presente. São inexistentes concepções de que é possível o crescimento econômico com proteção ambiental e justiça social. Também são silenciados discursos que acreditam que a política 'verde' e a tecnologia 'verde' podem gerar riqueza. Pelas próprias condições de produção dos discursos dessas revistas, também estão ausentes os discursos de Mudanças radicais que rejeitam a estrutura da sociedade industrial. Por vezes, surgem alguns traços de romantismo verde, discursos que consideram que a relação entre os homens e a natureza tem sido violada e que a mudança "vem de dentro".

\subsection{Discurso quanto ao desastre}

Do ponto de vista das concepções sobre os desastres, buscamos Gilbert (1995), para quem os desastres podem ser vistos do ponto de vista das Causas Externas, da Vulnerabilidade ou do Estado de Incertezas.

As concepções que concebem os desastres como Agentes externos priorizam os agentes destrutivos e excluem os comportamentos humanos. Outras preferem conceber o desastre como expressão social da Vulnerabilidade. Os riscos são produzidos socialmente e procedem da incisiva intervenção humana sobre o meio. A natureza dos desastres está na organização social, como um processo ligado à vulnerabilidade. Suas causas são problemas estruturais. A vulnerabilidade tem dimensões políticas e diz respeito a grupos excluídos das arenas decisórias. O desastre é um efeito é 
resultado de falha de medidas de proteção. Outra concepção do desastre o concebe como um Estado de Incertezas geradas pelas próprias instituições. As incertezas podem ser compreendidas como produzidas pelas sociedades complexas, a partir de articulações fracas entre as especialidades científicas e de vácuos de representação e dificuldades com práticas de redução de riscos.

\subsection{Discurso quanto aos envolvidos}

Para Valêncio (2010), frações de Estado envolvidas tanto no planejamento da emergência quanto nos cenários de destruição, produzem os enunciados da Imprevidência, da Fatalidade e da Superação ao desastre.

O enunciado da Imprevidência do afetado enfatiza aqueles que são cientes do risco, mas não se preparam para enfrentá-lo. Para a autora, o ato de impingir culpa aos afetados pelos danos e prejuízos havidos derivam de uma Formação Discursiva com três propósitos mais evidentes: mascarar a omissão e/ou ineficácia do Estado e legitimando sua aparição apenas diante o fato consumado; negar os direitos da pessoa, julgá-la sumariamente junto à opinião pública e desviar a atenção pública do contexto macro de injustiça ambiental e irresolução dos conflitos relacionados à terra, no meio urbano e rural.

O enunciado da Fatalidade é "uma estratégia de tergiversação em torno de responsabilidades" (2010), torna invisíveis as omissões do Estado e a desigualdade social. Diz a autora que nenhum órgão específico se responsabiliza pelas responsabilidades. Valencio traz Bauman (1999, apud Valêncio, 2010) para lembrar que a fragmentação dos poderes é a fonte primária da força da modernidade tanto para que os problemas pareçam manejáveis ou jamais se ajustem na agenda ou, ainda, para sua discussão ser adiada indefinidamente. Lembra que os sentidos correntes de fatalidade remetem a um acontecimento imprevisível, como um destino incontrolável, uma desgraça.

O enunciado da Superação diz respeito à privatização da segurança. Diz Valêncio que a mídia explora os casos em que a perda dos bens e de entes queridos incita ao refazimento célere da moradia, do local de trabalho, do bairro, com o seu próprio suor. 
Quanto ao discurso do Estado no que diz respeito aos envolvidos, encontramos ocorrências de Fatalidade (FD A fúria da natureza), mas predominam os sentidos da Imprevidência (que abrigam duas FDs: Fomos nós que fizemos a chuva e Afogados no descaso). O Discurso de Superação também é bastante frequente nas revistas analisadas, mas não integra as Sequências Analisadas, que referiram-se unicamente às causas, força e frequência dos desastres.

\subsection{Discurso quanto ao risco}

Um grande debate envolve o tema, a partir de autores como Ulrich Beck (2010) e Nicklas Luhmann (2011). De maneira mais operacional, para fins de nosso trabalho, ressaltamos dois paradigmas para interpretar o risco: o Comportamental e o Estrutural (SMITH, 1992). O Comportamental refere-se a um ponto de vista ecológico. Trata-se de um paradigma hegemônico, que enfatiza a explicação científica, a previsão e a necessidade de conter a natureza. Por isso, dedica-se aos planos de risco. Para o autor (1992: 42), "has also been criticized because it over-exaggerates the rol of the individual in hazards, either as a decision-maker or as victim."

O paradigma que interpreta o risco de modo estrutural enfatiza o papel das forças institucionais. Muito usado por cientistas sociais, faz uma ligação do risco e do desastre com o subdesenvolvimento, incluindo a necessidade de distribuição de riquezas. Cada risco não tem como única causa a natureza. Relaciona os riscos com a pobreza da população. Baseia-se na ideia que os desastres costumam ocorrem em áreas com rápidas mudanças ambientais e sociais. Ressalta que as vítimas dos desastres não devem ser culpadas por seus infortúnios e acredita que o subdesenvolvimento não é um estado temporário, mas fruto de um processo deliberado.

Duas Formações Discursivas se amparam numa visão comportamental quanto ao Risco, as FDs Fomos nós que fizemos a chuva e a Afogados no descaso. A cobertura das catástrofes que envolvem o ambiente fica circunscrita a uma concepção de risco de um ponto de vista gerencial. E nenhuma sublinha os problemas estruturais. Como afirma Valencio, os "dramas sociais - que imbricam aspectos socioeconômicos, sociopolíticos, socioculturais e psicossociais de desintegração e deterioração - são escamoteados pela pujança do 
discurso tecnocientífico em torno dos desastres, especialmente daqueles ditos 'naturais', forçando os olhares e preocupações da opinião pública para o monitoramente dos fatores de ameaça que, pressupostamente, seriam externos ao processo social.” (2014: 1)

\section{Considerações finais}

Pelas Formações Discursivas predominantes, vemos que a inação do homem no plano gerencial é apontada como a principal causa das catástrofes, como mostramos na Formação Afogados no Descaso, embora a Formação intitulada A fúria da natureza ainda seja bastante apresentada como causadora dos desastres. A FD Fomos nós que fizemos a chuva, que dá conta da relação do homem com o ambiente, é minoritária.

Os sentidos produzidos pela FD dominante dão conta de uma responsabilidade humana circunscrita a algumas esferas e, sobretudo, de uma visão limitada da vulnerabilidade social. Há o encontro entre o desastre natural e o desastre social, embora de maneira frágil.

Esses dois tipos de catástrofes tinham sido mantidos à parte na história da modernidade, como mostra Bauman (2008). O autor recorre à Susan Neiman, que estuda a sucessão de interpretações sobre o mal na história moderna, para lembrar que talvez a separação entre os conceitos de desastre natural e social, "antes indissoluvelmente misturados na ideia da vontade de Deus separação que teve lugar no curso dos acesos debates desencadeados pelo terremoto e incêndio de Lisboa em 1755, assinale o verdadeiro início do 'moderno'” (2008: 108). Acreditou-se que a natureza seria absorvida ao domínio da cultura humana e, por isso, submetida a uma administração exclusivamente humana, o que não ocorreu. E, assim, surgiu a expressão "catástrofe natural", elevando o que ela tem de radical e escondendo o que ela carrega consigo de responsabilidade humana. A cobertura midiática dá conta da ideia de que a catástrofe não é apenas "natural", mas desastre social ainda é apresentado de maneira frágil.

Podemos citar como exemplo o terremoto e maremoto que arruinaram Lisboa em 1755, que geraram um ambiente produtivo para os ideais iluministas. O Santo Ofício perdeu prestígio e poder 
após a beata Lisboa ser destruída em pleno Dia de todos os Santos (Shrady, 2011). Jean-Jacques Rousseau inocenta Deus e a natureza de toda culpa e responsabiliza os homens por terem construído casas amontoadas às margens do rio Tejo. Como já pontuou a própria revista Veja, um de nossos objetos de estudo, na matéria intitulada "Quando Deus tremeu”, em 16 de março de 2011, dois terremotos aconteceram em Lisboa em 1755 dois: um geológico e outro filosófico.

"Em 1755, o terremoto de Lisboa propiciou aos iluministas a oportunidade de demonstrar a irracionalidade religiosa. Passados dois séculos e meio, já não se acredita tanto que vivemos no melhor dos mundos. Mas é grande a crença de que um dia sobrepujaremos a natureza por meio da ciência e tecnologia. Trocamos apenas de religião.” (Revista Veja, 2011)

A catástrofe como figura moderna é ocasionada também pela ação do homem. Terremotos, tsunamis e deslizamentos vistos na atualidade impossibilitam a divisão entre o que é humano ou simplesmente natural:

"si en el passado muchos de los daños inexplicabes se atribuían a los dioses, a la naturaleza o simplesmente al destino, em la actualidad prácticamente todos los peligros que nos amenazan (...) se deben, em princípio, a decisiones humanas (...)." (Lozano Ascêncio, 2006: 291)

Entretanto, o discurso da responsabilidade do homem perante as catástrofes pode assumir várias nuances e a cobertura jornalística é construtora deste acontecer catastrófico

Bauman (2008) colabora com a compreensão dos discursos tanto sobre os desastres como sobre os riscos. Afirma que o homem moderno tende a colocar tudo sob um discurso gerencial, o que parece evidente no caso do Tsunami da Tailândia, quando foi dado destaque à falta de providências (inclusive na não emissão do alarme para não prejudicar a indústria turística) para evitar a tragédia. Mas no caso de Nova Orleans, lembra o autor que havia um sistema de alarme e todos tiveram tempo para procurar abrigo. Este caso implodiu os aspectos gerenciais, por mais que eles tenham sido 
reiterados. As desigualdades sociais ficaram evidentes, pois nem todos tinham dinheiro para comprar passagens aéreas ou para pagar hotéis fora da cidade. $\mathrm{O}$ marcador de raça e classe ficou claro entre quem foi e quem não foi atingido (Bauman, 2008: 104). Assim, os desastres naturais, a uma primeira vista, parecem atingir todos equitativamente, mas há uma distribuição da imunidade. Para o autor, talvez o Katrina tenha ajudado a remover os supostos "dejetos humanos" naquela região. Um exemplo do descaso com parte da população foi o toque de recolher num ambiente caótico, em que as pessoas buscavam desesperadamente água e alimentação.

A burocracia libertou os executores da responsabilidade sobre seus resultados porque substituiu a "responsabilidade por" pela "responsabilidade perante", "a responsabilidade pelo impacto de uma ação sobre seu objeto pela responsabilidade perante o superior, o ordenador." (Bauman, 2008: 116). As origens da ordem e a autoridade se localizam em um distante e nebuloso: 'lá em cima' - e com duplo efeito: primeiro (relembrando a feliz expressão de Hanna Arendt), "uma responsabilidade 'flutuante', tornando quase impossível localizá-la e atribuí-la com precisão, transformando-a, para todos os fins práticos, numa responsabilidade 'de ninguém [....]." (2008: 116).

"Os dramas sociais - que imbricam aspectos socioeconômicos, sociopolíticos, socioculturais e psicossociais de desintegração e deterioração - são escamoteados pela pujança do discurso tecnocientífico em torno dos desastres, especialmente daqueles ditos 'naturais', forçando os olhares e preocupações da opinião pública para o monitoramente dos fatores de ameaça que, pressupostamente, seriam externos ao processo social." (Valencio, 2013)

Nosso estudo mostra, como diz Orlandi, que os discursos sobre o futuro dos recursos são em geral reformistas, "esvaziam assim o social como estruturante e ficam em seus efeitos, falando ou do muito geral e abstrato - os cálculos economicistas - ou do que só tem micro alcance - desliza para o indivíduo.” (2012: 147). As revistas brasileiras privilegiam determinados sentidos sobre as tragédias e suas relações com questões sociais, econômicas e ambientais e assim 
traçam os contornos de como as catástrofes devem ser percebidas publicamente.

\section{Referências bibliográficas}

ASSOCIAÇÃO NACIONAL DE EDITORES DE REVISTA. Circulação média de janeiro a dezembro de 2013. Disponível em http://www.aner.org.br. Acesso em 15 jun. 2014.

BAUMAN, Zygmunt. (2008): Medo Líquido. Rio de Janeiro: Zahar.

BECK, Ulrich. (2010): Sociedade de risco - rumo a uma outra modernidade. São Paulo: Editora 34.

BIRD, Elisabeth e DARDENNE, Roberto. (1999): "Mito, Registros e "estórias"”. Em VV. AA., Jornalismo: questões, e "estórias" (Coord., TRAQUINA, Nelson). Lisboa: Vega, 2a ed. p. 263-288

CHARAUDEAU, Patrick e MAINGUENEAU, Dominique. (2004):

Dicionário de Análise do Discurso. INTERDISCURSO. São Paulo: Contexto. p.286-288

. (2004): Dicionário de Análise do Discurso. FORMAÇÕES DISCURSIVAS. São Paulo: Contexto. p.240-242

DRYZEK, John. (2005): The politics of the Earth- environmental discourses, Oxford University Press: New York.

GILBERT, Claude. (1995): Studing disaster: a review of the main conceptual tools. Internacional Journal off mass emergencies and disaster. November, Vol 13, No 3, p. 231-240.

LÓPEZ, Marisa. (1999): La contribución de la Antropología al estudio de los desastres: el caso del huracán Mitch en Honduras y Nicaragua, Departamento de Antropología, University of Florida, USA.

LOZANO ASCÊNCIO, Carlos. (2001): El medio ambiente: un acontecer catastrófico. Comunicación presentada al VII Congreso Español de Sociología (FES). Universidad de Salamanca. Septiembre.

- (2004): La expresión/representación de catástrofes a traves de su divulgación científica em los médios de comunicación social (1986-1991). Tesis doctoral. Madrid. Universidad Complutense de Madrid.

. (2005): “Aportaciones para una historia del acontecer catastrófico.” Em 
VV. AA., Ciências da Comunicação em Congresso na Covilhã, Actas do III Sopcom, VI Lusocom e II Ibérico Universidade da Beira Interior (Coord., FIDALGO, Antônio e SERRA, Paulo), Covilhã, Volume III.

. (2009): "La actualidad informativa como fuente de incertitumbres." Em

VV. AA., Comunicar los riesgos. Ciência y tecnologia en la sociedade de la información (Coord. MORENO, Carolina.) Madrid, Biblioteca Nueva, p,231248.

. (2013): El Cambio climáto em los telediarios: alusiones a la catástrofe em tempos de calma Anuario electrónico de estúdios em Comunicación Social. Volumen 6, Numero 1/Enero-Junio.

LUHMANN, Nicklas. (2011): “El concepto de riesgo.” Em VV. AA., Las consecuencias perversas de la modernidade (Coord., BERIAIN, Josetxo). Barcelona: Antrophos Editorial.

MOLOCHT e LESTER. (1993): "Notícias como procedimento intencional: a cerca do uso estratégico de acontecimentos de rotina, acidentes e escândalos." Em VV. AA., Jornalismo - questões, teorias e estórias (Coord. TRAQUINA, Nelson). Lisboa: Vega. p. 34-51

NESTROVSKY, Arthur e SELIGMANN-SILVA, Márcio (orgs). (2000):

Catástrofe e representação. São Paulo: Escuta.

ORLANDI, Eni. (2002): Análise do Discurso: princípios e procedimentos, $4^{a}$ ed, Pontes.

. (1996): Discurso e leitura. 3.ed., Campinas: Editora da UNICAMP.

. (2012): Discurso em Análise: sujeito, sentido e ideologia. $2^{\mathrm{a}}$ ed Campinas, SP, Pontes.

PÊCHEUX, Michel. (1988): Semântica e discurso - uma crítica à afirmação do óbvio. Campinas, Ed. da Unicamp.

PERROW , Charles. (2007): The next catástrofe - reducing our vulnerabilities to natural, industrial and terrorist disasters. Princenton: Princenton University Press.

REVISTA VEJA. Quando Deus Tremeu. Edição 2208 de 16 de março de 2011.

SERRA, Joaquim Paulo. (2006): Cataclismos e catástrofes: reflexões acerca da relação entre sistema político e sistema mediático. Universidade da Beira Interior.

SHRADY, Nicholas. (2011): O última dia do mundo - fúria, ruína e razão no grande terremoto de Lisboa de 1755. Rio de Janeiro: Objetiva. 
SCHWAAB, Reges e ZAMIN, Angela. (2014): "O discurso jornalístico e a noção-conceito de interdiscurso”, en Revista Vozes e Diálogos, 13. Itajaí, n. 01, páginas 046 a 062, jan./jun.

SMITH , Keith. (1992): Environmental Hazards - assessing risk \& reducing disaster. London: Routlege.

VALENCIO, Norma. "Desastres, ordem social e planejamento em defesa civil: o contexto brasileiro", en Saúde e Sociedade, 19. USP. Impresso, páginas 748 a 762, 2010.

"Processos de Vulnerabilização envolvendo comunidades pesqueiras no Brasil: dos desastres recentes aos riscos relacionados às mudanças climáticas." Revista de Comunicação e Educação Ambiental, 3. Páginas 106 a 120; recuperado El 12 de junho de 2014, de http://gestaoecossistemas.files.wordpress.com/2012/11/i-1-processos-devulnerabilizac3a7c3a3o-envolvendo-comunidades-pesqueiras-no-brasil-dosdesastres-recentes-aos-riscos-relacionados-c3a0s-mudanc3a7asclimc3a1ticas.pdf

*O paper integra a investigação intitulada "Especificidades da cobertura das catástrofes ambientais nas revistas semanais brasileiras: das fontes jornalísticas à construção dos sentidos". A pesquisa tem a participação da aluna de Graduação, bolsista de Iniciação Científica Dafne Lopes e o apoio do Conselho Nacional de Pesquisa (Brasil). 



\title{
Las prospecciones petrolíferas en el Golfo de Valencia en prensa española
}

\author{
Ma Teresa Mercado Sáez - Universidad CEU Cardenal Herrera - \\ mmercado@uch.ceu.es
}

Fernando Sahuquillo Verdet - Universidad CEU Cardenal Herrera fernando.sahuquillo@,uch.ceu.es

Resumen: La solicitud de autorización al Gobierno español para la realización de prospecciones petrolíferas en el Golfo de Valencia y en Canarias ha generado un debate social en torno a los beneficios y riesgos que conllevaría la explotación de petróleo en las zonas afectadas. En el caso mediterráneo, el gobierno de José Luis Rodríguez Zapatero aprobó en 2010 dos reales decretos por los que, entre otros, se otorgaban a la multinacional Cairn Energy, a través de Capricorn Spain, permisos de investigación de hidrocarburos en el Golfo de Valencia. Tres años después, la empresa solicitaba permiso para la Campaña de Adquisición Sísmica 3D, entre Ibiza y Formentera y la costa valenciana, lo que provocó la movilización de miles de ciudadanos que se manifestaron en contra en la Comunidad Valenciana y las Islas Baleares.

Desde la perspectiva teórica del framing, los objetivos de la investigación son descubrir los encuadres noticiosos y principales actores/fuentes en el debate sobre las prospecciones en el Golfo de Valencia a partir del análisis de dos diarios, El País y Abc. El objetivo 
de esta investigación es determinar si el asunto 'prospecciones petrolíferas en el Golfo de Valencia' aparece en los medios en términos de beneficio o riesgo.

La muestra está compuesta por aquellos textos en los que aparezcan las palabras clave 'prospecciones petrolíferas' en dos momento claves: los dos meses siguientes a la aprobación en diciembre de 2010 y los dos primeros meses de 2014 cuando la empresa pretende iniciar los sondeos y surge la contestación social.

Los resultados muestran que estos diarios informan acerca de este asunto relacionado con la energía en términos de beneficio (económico) y riesgo (ambiental pero también económico) siendo los políticos los actores principales. La investigación forma parte del proyecto del Plan Nacional I+D+i referencia CSO2012-38363.

Palabras clave: encuadres noticiosos; framing; política energética; prospecciones petrolíferas.

\section{Introducción}

— N ESPAÑA, el Consejo de Ministros autorizaba el 23 de diciembre de 2010 la investigación de prospecciones de hidrocarburos frente a las costas de Málaga, Cádiz, Valencia y Cantabria. Según el Gobierno, las actividades de prospección de hidrocarburos "tienen un interés estratégico y económico evidente" para un país que, como España, depende en más de un 99,5\% de las importaciones de gas y petróleo: "Es aconsejable fomentar la prospección de nuestros recursos naturales siempre que se realicen de una manera sostenible". Las zonas en las que se puede investigar son la denominada "Chinook A-D", frente a la costa de Málaga; "Luena", en una área compartida por las Comunidades Autónomas de Cantabria y Castilla y León; "Tesorillo y Ruedalabola", en la provincia de Cádiz y zonas de subsuelo marino, y "Albufera, Benifayó y Gandía" y "Alta Mar 1 y 2", en el Golfo de Valencia. El Ejecutivo central aclaró que las licencias permiten investigar en exclusiva la existencia de bolsas de hidrocarburo (gas o petróleo) en el área limitada pero no suponen un permiso de explotación. 
En Valencia, la petición de Medoil (absorbida más tarde por Cairn Energy) en 2006 se centraba en los alrededores de la Albufera, Gandia y Benifaió, un área marítima de 238.140 hectáreas situadas entre Sagunto y Gandía. Las zonas en las que se podría actuar se encuentran a escasos metros de la playa del Saler y amenazan el Parque Natural de la Albufera.

La empresa con sede en Edimburgo, a través de la filial Capricorn Oil, amplió su solicitud en septiembre de 2008 a dos franjas más, denominadas Alta Mar 1 y Alta Mar 2, ubicadas junto a las otras y que ocupan 79.380 hectáreas más cada una. La profundidad del agua en la zona delimitada oscila entre los 50 y los 2.000 metros. Según apuntaron fuentes de Medoil, "los dos primeros años los trabajos serían de oficina". Será una fase de estudio, que ya arrojará los primeros resultados y se elaborarán diferentes informes, entre los que se encuentran los de protección del medio ambiente. Después comenzarían las tareas sobre el terreno.

Tres años después, la empresa solicitaba permiso para la Campaña de Adquisición Sísmica 3D, entre Ibiza y Formentera y la costa valenciana. El 22 de febrero de 2014 miles de ciudadanos se manifestaban en Castellón y Baleares en contra de las prospecciones.

Este trabajo se propone analizar cómo es presentada la información sobre los permisos para las prospecciones petrolíferas en el Golfo de Valencia a partir del análisis de contenido y la teoría del framing. Los objetivos de la investigación son, por una parte, descubrir los encuadres noticiosos de los medios respecto a este asunto concreto. Por otra, determinar los actores principales que aparecen en estas informaciones. Esta aproximación permitirá descubrir los encuadres noticiosos y profundizar en la red de significados latentes que subyace en ellos en un asunto como la explotación de recursos en el entorno de un espacio protegido.

Las preguntas de investigación son:

1. ¿Informan los diarios españoles en términos de encuadres beneficio/riesgo en relación a las prospecciones petrolíferas?

2. ¿Aparecen diferencias en el tratamiento informativo en relación al ámbito de difusión y la línea editorial? 
3. ¿Quiénes son los principales actores en el debate?

\section{Metodología}

La técnica utilizada para el análisis del tratamiento informativo de la cuestión energética en los diarios nacionales es la del análisis de contenido incorporando variables que permitan determinar los encuadres básicos de las piezas siguiendo la teoría del framing.

El análisis de contenido es considerado un método de estudio de la comunicación de forma sistemática, objetiva y cuantitativa, que permite examinar científicamente "tanto los significados como los significantes de cualquier texto (Bardin, 1986; Wimmer y Dominick, 1996; Kripendorf, 1990; Gaitán y Piñuel, 1998). Además, “permite obtener descripciones sumarias de mensajes de naturaleza muy variada, entre estos, los manifiestos versus latentes y rasgos formales versus atributos de contenido" (Neuendorf, 2002), considerando estos constructos o variables latentes decisivos para la presente investigación. En definitiva, esta aproximación permitirá descubrir los encuadres ocultos a primera vista. Los estudios de framing principalmente tratan de explicar el tratamiento informativo de temas políticos relevantes como el que constituye nuestro objeto de estudio.

Para desvelar los encuadres desde la perspectiva teórica citada, se opta por determinar la aparición de la primera de las funciones básicas establecidos por Entman (1993: 52): el encuadre promueve una particular definición del problema ("determine what a causal agent is doing with what costs and benefits, usually measured in terms of common cultural values"). En este caso se trata de plantear si se ofrece una visión de las catas petrolíferas centrada en los riesgos que suponen o en los beneficios que pueden lograr.

Son dos los periodos a analizar: el primero abarca desde el 23 de diciembre de 2010, momento en el que, como se ha señalado anteriormente, el gobierno de Zapatero autoriza los permisos de investigación de hidrocarburos en el Golfo de Valencia, hasta el 23 de febrero de 2011. El segundo periodo, tres años después, cubre los dos primeros meses de 2014 (1 enero a 28 de febrero), cuando la empresa Capricorn Spain Limited solicitaba permiso para la 
Campaña de Adquisición Sísmica 3D, entre Ibiza y Formentera y la costa valenciana, produciéndose una contestación ciudadana.

Los periódicos analizados son los diarios de ámbito nacional El País y Abc y las unidades de análisis serán todos aquellos textos en los que se haga referencia a las palabras claves 'prospecciones petrolíferas', 'petróleo', 'crudo'. Para su identificación se procede a una doble búsqueda: en las hemerotecas digitales de las ediciones on line de los diarios y a través del servicio de clipping de MyNews, que ofrece la posibilidad de obtener las páginas en pdf de los diarios.

Siguiendo a Igartua (2006), se lleva a cabo un programa de codificación que recoge las variables descriptivas en cada unidad de análisis:

a) Datos de identificación: fecha de publicación, cabecera, sección, titular, autoría (firma) y edición (nacional o local).

b) Datos de caracterización formal: ubicación, apoyo gráfico, género periodístico.

c) Datos de caracterización informativa: número de fuentes, fuentes mencionadas, actor principal y encuadre básico. Se consideran actores y temas principales aquellos con mayor presencia y/o que aparecen en los elementos de titulación y entradillas de las piezas puesto que ofrecen al lector los elementos noticiosos más importantes. Para definir el encuadre, el analista responde a la cuestión acerca de cómo se define el problema en términos de beneficio o riesgo.

\section{Resultados}

Durante el primer periodo del estudio (23/12/2010 - 23/02/2011) el diario $A b c$ presenta un total de 43 unidades de análisis. La mayoría de ellas (30) están incluidas en la sección regional, en este caso, Comunitat $(69 \%)$. El resto (8) quedan recogidas en páginas locales $(18 \%)$ y Otras (5) (11\%). Por su parte, El País, dedica al asunto 29 piezas, de la cuales $28(96 \%)$ están publicadas en la sección regional.

Las cifras se reducen considerablemente en el segundo periodo (01/01/2014 - 28/02/2014). Las unidades totales de análisis son 8 en $A B C$ y 9 en el diario El País. En cuanto al primero, 3 se incluyen en la sección regional (37\%); 2 en la sección Nacional (25\%); dos en otras 
secciones (25\%) y 1 en Sociedad (12\%). El País sigue incluyendo la mayoría de las piezas (7) en la sección Comunitat (77\%). El resto, una en Nacional (11\%) y otra en Sociedad (11\%).

El género más utilizado en ambos periodos de la investigación es la noticia. En la primera parte, $A b c$ opta por el género informativo de referencia en 26 casos (60\%); el reportaje en 3 casos (7\%) y la entrevista en uno $(2 \%)$. En cuanto a géneros de opinión, se dedican 9 sueltos (21\%); 3 columnas de colaboradores fijos (7\%) y un artículo (2\%). El diario El País en este caso opta por el género noticia en todas las piezas de esta parte de la muestra. En el segundo periodo, sin embargo, se sirve casi a partes iguales de la noticia (5) y el reportaje (4). Suponen el $55 \%$ y el $44 \%$, respectivamente. En este caso, $A b c$ mantiene la noticia (24) como el género más empleado $(82 \%)$. Además, publica 2 reportajes (7\%); una entrevista $(3 \%)$ y 2 columnas $(7 \%)$.

Entre los autores, la mayoría de las piezas correspondientes a ambos periodos en $A b c$ aparecen firmadas por periodistas de la redacción. En el primer caso son 23 (53\%), mientras que son 5 en el segundo $(62 \%)$. Llevan firma genérica de redacción o agencias 5 unidades del primer periodo (11\%) y 1 en el segundo (12\%). En cuanto al resto de opciones posibles, 11 ítems aparecen sin firma en el primer periodo $(25 \%)$ y dos en el segundo (25\%). Se trata en su mayoría de breves y sueltos. En la primera fase aparecen, además, 3 piezas firmadas por colaboradores fijos $(7 \%)$ y una con firma invitada (2\%). En lo que se refiere a El País, en el primer periodo, 17 ítems contienen la firma de un periodista de redacción (58\%); dos aparecen sin firma (7\%) y otros dos llevan la firma de un colaborador (7\%). En ocho casos $(27 \%)$ la firma es genérica. En el segundo periodo, 8 piezas (89\%) llevan la firma de un periodista. Una (11\%) lleva firma genérica de la redacción.

Por otra parte, del total de unidades publicadas por el diario $A b c$ en el primer periodo, 25 cuentan con el apoyo de una fotografía $(58 \%)$, mientras que 18 no van acompañadas de ningún apoyo gráfico (42\%). En la segunda fase, 6 ítems incluyen fotografía (75\%) y dos no llevan ningún apoyo (25\%). En este caso, El País publica en la primera parte ítems con fotografía como apoyo en 12 ocasiones (41\%) y sin ningún apoyo en 16 casos (55\%). En una de las unidades (3\%) el apoyo 
gráfico lo constituye una fotografía con algún otro elemento gráfico (tabla, cuadro de datos, etc.). En el segundo periodo, en cuatro ocasiones el apoyo es únicamente una fotografía (44\%) y en tres no existe apoyo de este tipo (33\%). En dos ocasiones, El País apoya la pieza de análisis con un gráfico $(22 \%)$.

Los políticos son la fuente de referencia cuando se habla de prospecciones petrolíferas en el golfo de Valencia. Del total de unidades de análisis publicadas en $A b c$ en la primera fase del análisis, 34 tienen como actor principal a los políticos (79\%). Sólo en una ocasión lo son las empresas petrolíferas $(2 \%)$ o las organizaciones ecologistas $(2 \%)$. En siete casos no consta ningún actor/protagonista $(16 \%)$. En la segunda parte, los políticos son protagonistas en 4 casos $(50 \%)$; los pescadores en dos $(25 \%)$ y la sociedad civil en otros dos $(25 \%)$.

El diario El País en la primera fase muestra como actor principal a los políticos en 25 piezas (86\%); a la sociedad civil en dos $(7 \%)$ y a empresas petrolíferas y ecologistas en una (3\% en ambos casos). En la segunda parte políticos (3) y pescadores (3) comparten protagonismo en el 33\% de los casos, respectivamente. Las empresas petrolíferas (1), los ecologistas (1) y la sociedad civil (1) son el actor principal en el $11 \%$ de las unidades.

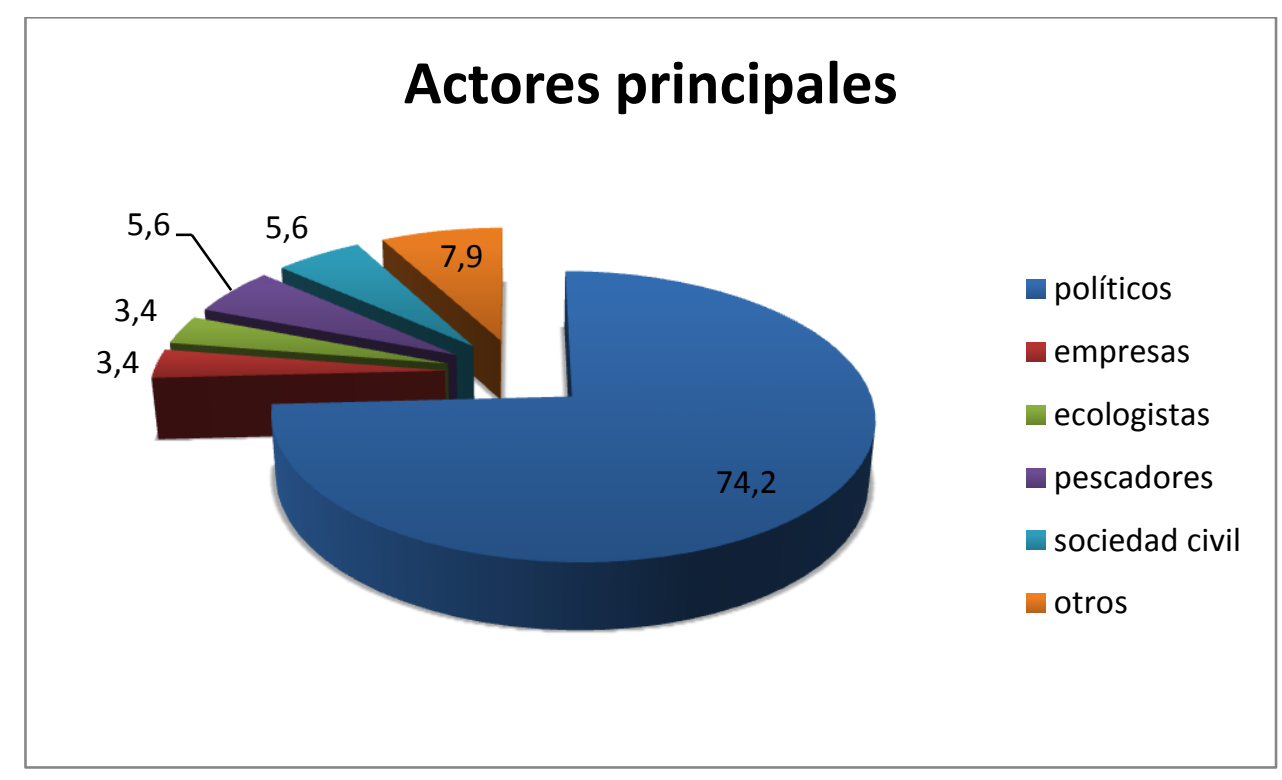

Gráfico 1: Actores principales en el diario $A b c$ y El País en ambos periodos analizados. Fuente: elaboración propia 
En cuanto al número de fuentes empleadas en las unidades de análisis, en 18 ocasiones (42\%) se cita una única fuente en la primera fase de $A b c$. En 10 casos (23\%) aparecen citadas dos fuentes; en 6 casos, tres fuentes $(14 \%)$, mientras que en 9 ocasiones no se cita ninguna fuente $(21 \%)$. En el segundo periodo, en 6 unidades se cita una fuente $(75 \%)$; y en una ocasión se citan dos $(12 \%)$ y tres fuentes $(12 \%)$. En el primer periodo, El País cita una fuente en 8 piezas (27\%); dos fuentes en 9 unidades (31\%); tres fuentes en 3 ocasiones $(10 \%)$; cuatro en 4 casos (14\%); y más de seis en 1 ocasión (3\%). En tres casos no hay fuentes citadas $(10 \%)$. En la segunda parte, hasta en cuatro ocasiones vienen citadas más de seis fuentes (44\%). Asimismo, se cita una fuente en dos casos (22\%); cuatro, cinco o ninguna en una $(11 \%)$.

Concretando las fuentes, el diario $A b c$, en el primer periodo analizado, cita a favor al Ministerio de Industria (2), al ministro de Industria, Miguel Sebastián (1), a la delegada del Gobierno, Ana Botella (3) y al Gobierno central (1). En contra, el presidente de la Mesa del Turismo, Abel Matutes (1); el portavoz socialista en Les Corts, Ángel Luna (1); el secretario del Partido Popular en Andalucía, Antonio Sanz (1); ayuntamientos gobernados por el PSOE (1); cofradías de pescadores (1); el vicesecretario de comunicación del Partido Popular, Esteban González Pons (3); el presidente de la Generalitat Valenciana, Francisco Camps (2); Generalitat (1); Greenpeace (1); candidato del PSPV a la alcaldía de Valencia, Joan Calabuig (1); el secretario general del PSPV, Jorge Alarte (1); José Luis Torró (2); el alcalde de Gandía, José Manuel Orengo (2); el vicepresidente tercero de la Generalitat y conceller de Medio Ambiente, Juan Cotino (3); Juanjo Braulio (1); Junta Rectora Extraordinaria del Parque Natural de la Albufera (2); el conceller de Infraestructuras y Transporte, Mario Flores, (1); PPCV (1); el portavoz del PP en Les Corts y conceller de Solidaridad, Rafael Blasco (2); la alcaldesa de Valencia, Rita Barberá, (5); SEO/Birdlife (1); conseller de Gobernación, Serafín Castellano (1); WWF (1). En una posición neutral encontramos al secretario general del PSPV, Jorge Alarte (2); a la delegada del Gobierno, Ana Botella (1); Repsol (1); el ministro de Política Territorial, Manuel Chaves (3). 
En el segundo periodo, $A b c$ cita a favor al ministro de Industria, José Manuel Soria (1); al portavoz del PP en Baleares, Miguel Ramis (1); la Asociación Española de Compañías de Investigación, Exploración y Producción de Hidrocarburos y Almacenamiento Subterráneo (ACIEP) (1). En contra, al Parlamento Balear (1); el Consejo de Ibiza (1); al presidente de la Federación de Cofradías de la Provincia de Alicante (1); la Asociación Mar Blava (1); la Comisión Interfederativa de Cofradías de Pescadores de la Comunitat Valenciana (1). En posición neutra, el ministro de Industria, José Manuel Soria (1).

El periódico El País, por su parte, cita a favor en el primer periodo a la delegada del Gobierno, Ana Botella (1) y a Josep Torrent (1). En contra, el portavoz del grupo en Les Corts, Adolf Sanmartín (1); primer teniente de alcalde del ayuntamiento de Valencia, Alfonso Grau (1); presidente de la Diputación de Valencia, Alfonso Rus (1); secretario general del PPCV, Antonio Clemente (5); la Asociación de Vecinos de Nazaret (1); portavoz en Alicante de Ecologistas en Acción, Carlos Arribas (1); edil socialista en el ayuntamiento de Valencia, Carmina del Río (1); portavoz del PP en Les Corts, David Serra (2); portavoz de Compromís en Les Corts, Enric Morera (2); vicescretario de Comunicación del PP, Esteban González Pons (3); Fernando Mut, de la Plataforma Gandia (1); presidente de la Comunitat Valenciana, Francisco Camps (1); secretario general del PSPV, Jorge Alarte (2); alcalde de Gandía, José Manuel Orengo (3); vicepresidente tercero de la Generalitat y conseller de Medio Ambiente, Juan Cotino (4); Junta Rectora del Parque del Montgó (1); Junta Rectora del Parque Natural de la Albufera (1); diputado de Esquerra Unida, Lluís Torró (2); alcalde de Tavernes de la Valldigna, Manolo Vida (1); diputada de Compromís, Mireia Mollà (1); alcaldesa de Valencia, Rita Barberá (1); conseller de Gobernación, Serafín Castellano (1). En posición neutral, portavoz del PSPV en Les Corts, Ángel Luna (1); delegada del Gobierno, Ana Botella (2); catedrático de Puertos y Costas de la UPV, José Serra (1); ministro de Política Territorial (1); Els Verds dEl País Valencià (1); Acció Ecologista Agro (1).

En la segunda parte, encontramos a favor a Cairn Energy (3); la Asociación Española de Compañías de Investigación, Exploración y Producción de Hidrocarburos y Almacenamiento Subterráneo 
(ACIEP) (1). En contra, presidente de la Mesa del Turismo, Abel Matutes (1); Alejandro Sanz (1); alcalde de Castellón, Alfonso Bataller (1); alcalde de Peñíscola, AndrésMartínez (2); Asociación Mar Blava (2); Asociación Provincial de Empresarios de Hostelería y Turismo (1); Cámara de Comercio de Alicante (1); portavoz en Alicante de Ecologistas en Acción (1); portavoz de Mar Blava, Carlos Bravo (2); Círculo de Empresarios de Dénia (1); Confederación de Empresarios de Castellón (1); Confederación de Empresarios de Alicante (1); Consell de Formentera (1); Conselleria de Medio Ambiente (1); patrón mayor de Gandía, Domingo Ciurana (1); Ecologistas en Acción (1); vicesecretario de comunicación del PP, Esteban González Pons (1); Gobierno Balear (1); Grupo de Ornitología Balear (1); presidente de pescadores alicantinos, Ignacio Llorca (2); diputado de Compromís, Joan Baldoví (1); presidente de la Federación Balear de Cofradías de Pescadores, Joan Cànaves (1); secretario y abogado de comisión interfederativa de cofradías, José Ortega (2); presidente de Baleares, José Ramón Bauzà (1); Kate Moss (1); Los Verdes Valencia (1); alcalde de Benicarló, Marcelino Domingo (1); teniente de alcalde del Grau de Castelló, Marta Gallén (1); presidente de pescadores castellonenses, Miguel Castell (1); Miguel, vecino de Castellón (1); Oceana (1); Paris Hilton (1); Pau Donés (1); Paz Vega (1); Pleno del Parlamento de Baleares (1); director de investigación de Oceana Europa, Ricardo Aguilar (1); Sienna Miller (1); Sociedad Valenciana de Ornitología (1); Sophie Ellis-Bextor (1); Universitat Politécnica de Valencia (1); rector Universitat Jaume I, Vicent Climent (1); presidente de la federación de cofradías de pesca de Valencia, Víctor Pérez (1); portavoz del gobierno de Gandia, Víctor Soler (1). En postura neutra, portavoz del comisario europeo de Medio Ambiente (1); profesor y director del Laboratorio de Aplicaciones Bioacústicas (LAB) de la Universitat Politècnica de Catalunya, Michel André (1); geóloga marina del Instituto de Ciencias del Mar- CESIC, Belén Alonso (1); vicepresidente del Consell, José Císcar (1).

En la primera parte del análisis en el diario $A b c$ el tema es presentado como un riesgo tanto para el medioambiente (15) como para la economía (9) lo que supone el $34 \%$ y el $21 \%$ del total, respectivamente. Asimismo, en 19 casos (44\%) se ha considerado que no había información suficiente para asignar alguna de las funciones. 
Se trata de informaciones breves en las que no es apreciable el encuadre. En la segunda parte, el asunto sigue planteándose como un riesgo, ambiental en 5 casos $(62 \%)$ y económico en uno (12\%). En dos piezas $(25 \%)$ no ha sido asignada la función.

En la primera fase, El País, por su parte, presenta el asunto de las prospecciones como un posible beneficio económico en tres momentos (10\%). En catorce ocasiones, sin embargo, lo plantea como un riesgo ambiental (7) y económico (7), que suponen el $24 \%$ en ambos casos. En el año 2014 se propone como un riesgo ambiental en cuatro casos (44\%) y como un riesgo económico en tres (33\%). En la primera parte se ha considerado por no asignar ninguna función en doce ocasiones (41\%), mientras que en la segunda esto ha sucedido en dos casos $(22 \%)$.

Atendiendo a las cifras totales de los diarios, Abc y El País coinciden en presentar las prospecciones petrolíferas en el golfo de Valencia como un asunto que entraña, por una parte, un riesgo ambiental (39\% y 31\%, respectivamente) y, por otra, un riesgo asociado a sectores económicos como el turismo o la pesca (19\% y 26\%, respectivamente).

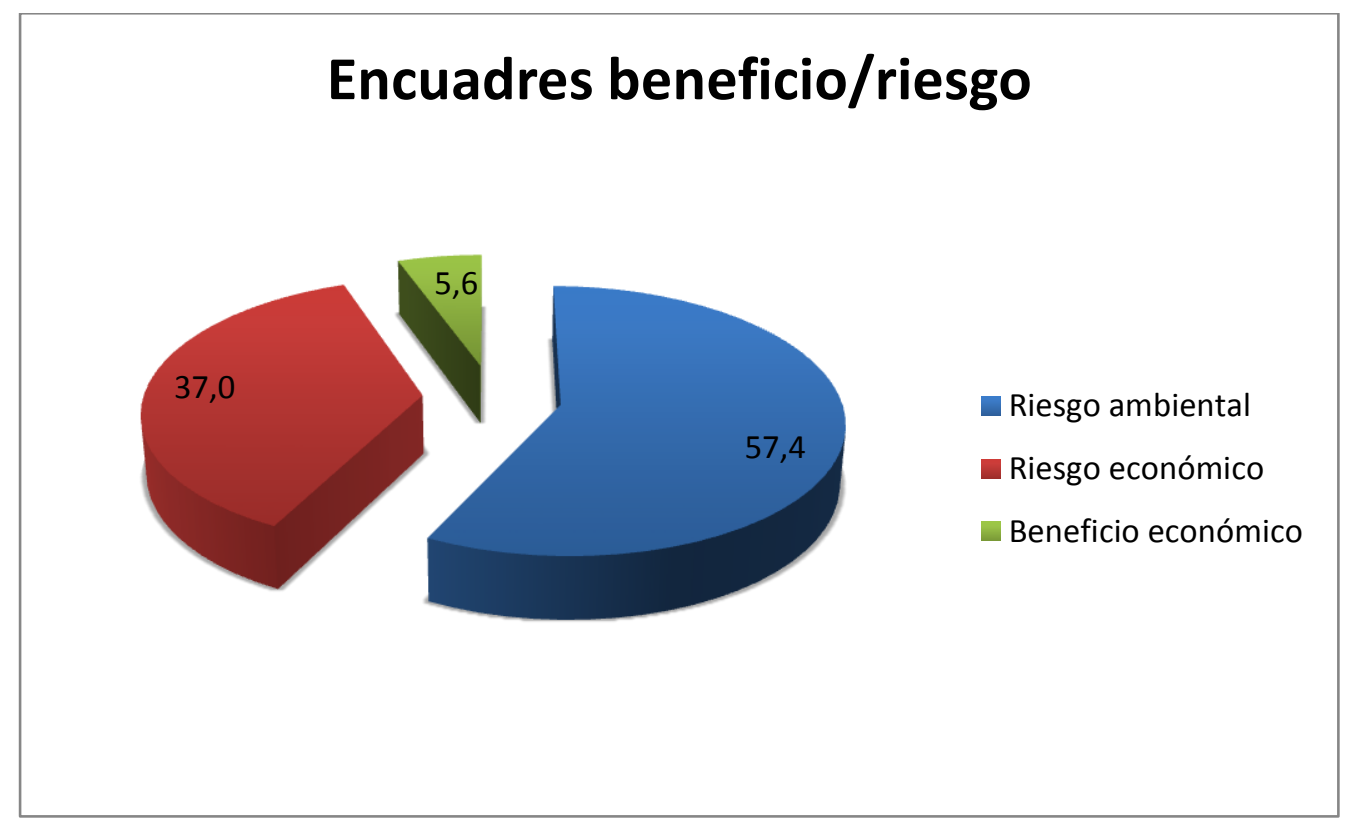

Gráfico 2: Porcentaje encuadres beneficio/riego en los diarios Abc y E1 País en ambos periodos analizados. Fuente: elaboración propia 


\section{Conclusiones}

Los diarios nacionales presentan un notable nivel de territorialización del conflicto al mostrarlo prácticamente en su totalidad en sus páginas regionales. El asunto únicamente salta de estas páginas a la edición nacional cuando se relaciona con otros casos, principalmente y por cercanía el balear. En este sentido, el reportaje de El País titulado "El furor del petróleo rodea Baleares" (16/02/2014) publicado en la sección Sociedad del suplemento Vida\&Artes repasa los cuatro proyectos de prospecciones pendientes en el mar Mediterráneo entre los cuales está incluido el del Golfo de Valencia. Así, el asunto queda presentado en general como un problema ligado al territorio valenciano.

Los datos del estudio revelan además la subrayable politización del debate. La clase política -la valenciana, concretamente, dada la territorialización antes referida- es la voz principal a la que recurren los diarios nacionales estudiados para tratar el asunto de las prospecciones. El protagonismo es destacable si se compara con la presencia de otros actores implicados como los sectores turístico y pesquero, las organizaciones ecologistas, o las empresas petrolíferas. Aún percibiéndose cierto consenso entre las fuerzas políticas mayoritarias de la región ("Frente común de PP y PSOE en Valencia contra los sondeos petrolíferos", Abc 29/12/2010), el problema de las prospecciones es uno más de los argumentos esgrimidos por los partidos en el debate político cotidiano: "Botella y Castellano mantienen las espadas en alto" (El País, 27/01/2011); "Cotino alienta otro conflicto de competencias por las prospecciones" (El País, 13/01/2011); "Camps dice que Zapatero busca petróleo para ser como Chávez" (Abc, 31/01/2011); "Chapapote preelectoral” (El País; 16/01/2011).

Sólo en la última parte del análisis, cuando se producen movilizaciones ciudadanas ("Más de 5.000 personas dicen 'no' a los sondeos en el Mediterráneo", El País 23/02/2014; "Miles de personas claman contra las prospecciones petrolíferas", Abc 19/02/2014) surgen nuevas voces. En ese momento entran en el debate, sobre todo, los pescadores: "El sector pesquero lleva al Supremo las prospecciones petrolíferas" ( $A b c, 27 / 02 / 2014)$. 
Conviene destacar la presencia casi testimonial de las organizaciones ecologistas. Ausencia de una voz que contrasta con el dominio del encuadre que se ha denominado "riesgo ambiental" en las informaciones de ambos periódicos nacionales. En este sentido destacan las referencias a la Albufera como espacio protegido que correría serio peligro de autorizarse las prospecciones: "Una Albufera renovada y sin prospecciones", titula $A b c$ el 03/02/2011, coincidiendo con el centenario de la cesión del lago al ayuntamiento de Valencia por parte de la Corona. Argumentando razones ambientales, el PP se posicionó desde el principio contra las intenciones del gobierno central. El vicesecretario de comunicación popular, Esteban González Pons, se oponía ya el mismo día del anuncio de la autorización de las prospecciones a una medida que podía "afectar a los intereses medioambientales y turísticos" de la región ("El Gobierno autoriza la búsqueda de petróleo en la costa valenciana", $A b c$ 24/12/2010).

El encuadre que se ha denominado "riesgo económico" se divide entre las referencias a la pesca y a al sector turístico. En "El Consell prepara los recursos contra la prospección petrolera" (El País 24/01/2011) el conseller de Medio Ambiente, Juan Cotino, una de las voces más activas del debate, auguraba la "pérdida de miles de puestos de trabajo". Por su parte, los pescadores de Alicante hablaban de "ruina" por la desaparición de algunas especies y la difusión de sedimentos contaminantes ("Los pescadores recurren al Gobierno central contra las prospecciones petrolíferas", $A b c$ 19/02/2014). En definitiva, los diarios nacionales plantean al asunto de las prospecciones petrolíferas en el golfo de Valencia como una decisión que plantea más riesgos que beneficios, sobre todo desde el punto de vista ambiental y económico. Sin embargo, el debate queda del todo convertido en argumento político por el predominio de dirigentes públicos como fuente principal de las informaciones.

\section{Referencias bibliográficas}

Bardin, L. (1986): El análisis de contenido. Madrid, Akal.

Entman, R. M. (1993): "Framing: toward clarification of a fractured paradigm". Journal of Communication, 43(3). 
Igartua, J. J. (2006): Métodos cuantitativos de investigación en comunicación. Bosch. Barcelona.

Krippendorff, K. (1990). Metodología de análisis de contenido. Teoría y práctica. Barcelona: Paidós.

Neuendorf, K.A. (2002): The content analysis guidebook. Thousand Oaks (CA): Sage Publications.

Wimmer, R.D. y Dominick, J. R. (1996): La investigación científica de los medios de comunicación. Una introducción a sus métodos. Barcelona: Bosch.

* Esta investigación forma parte del proyecto “Análisis del tratamiento informativo de las políticas energéticas en España, procesos de recepción y participación de organizaciones sociales" (Plan Nacional de I+D+i, referencia CSO2012-38363). 


\title{
Humanismo y desastres naturales: el caso de Omaira Sánchez y la erupción del Nevado del Ruiz
}

\author{
Sergio Mena Muñoz. Universidad Nebrija \\ smena@,nebrija.es
}

Resumen: El 13 de noviembre de 1985 la erupción del volcán Nevado del Ruiz, en Colombia, provocó una riada de lodo inesperada que arrasó por completo la pequeña localidad de Armero. Omaira Sánchez Garzón, de 13 años, dormía tranquilamente en su casa cuando de repente se vio atrapada entre troncos, ladrillos, piedras y cadáveres en medio de un enorme charco de agua que le llegaba a la comisura de los labios. Un equipo de TVE que se desplazó a cubrir el desastre la encontró en medio del caos y estuvo con ella convirtiendo por primera vez una catástrofe natural internacional en un fenómeno televiso en España. Omaira estuvo 72 horas tratando de ser rescatada, pero no fue posible y murió agonizando casi en directo mientras la opinión pública de un país extranjero hacía suyo su drama. Si la Guerra del Golfo fue la primera muestra de conflicto televisado de la historia, Omaira y el Nevado del Ruiz fue la primera vez que una catástrofe natural fue narrada televisivamente en España. Se puso cara y voz a un suceso que de otra manera hubiese pasado desapercibida del imaginario colectivo, a pesar de que en él murieron 25.000 personas. Este estudio pretende comparar el tratamiento que tuvo el desastre por parte de la prensa escrita con el que hizo Televisión Española, identificando qué elementos fueron novedosos en aquel 
momento y cuáles de ellos han sido utilizados posteriormente en eventos informativos similares.

Palabras clave: Humanidad; Televisión; Omaira Sánchez; Nevado del Ruiz; Colombia; Riada

\section{Introducción}

MAIRA Sánchez Garzón (u Omayra con y griega, como aparece escrito gráficamente su nombre en numerosas fuentes) era una niña más de la localidad colombiana de Armero, en el departamento de Colima. Había nacido en el seno de una familia humilde en 1972. Su padre, Álvaro Enrique, era un agricultor de la región de Santander que plantaba y recolectaba arroz y sorgo mientras que su madre, María Aleida, trabajaba en casa en compañía de su otro hijo, Álvaro Enrique, y su hermana María Adela.

La noche del 13 de noviembre de 1985 el volcán Nevado del Ruiz, de 5.321 metros y en cuya falda se encontraba la ciudad de Armero, erupcionó fundiendo las nieves que se encontraban en su cima. La lengua de barro y lava que formó rodó ladera abajo arrasando todo lo que iba encontrando a su paso, incluido toda Armero. Murieron 25.000 personas, Omaira Sánchez incluida. Los supervivientes de la tragedia recordaban a aquella niña como una estudiante brillante que durante su agonía sólo pensaba en poder volver al colegio (Belver, 2012).

Antes de la erupción, la madre de Omaira había viajado a la capital, Bogotá, para arreglar algunos negocios por lo que no se encontraba en casa en el momento del desastre. Aquella noche todos los que se quedaron en el hogar de los Sánchez Garzón estaban en vela, preocupados por el incesante caer de cenizas que había comenzado aquella tarde. Cuando oyeron llegar al estruendo, ya era demasiado tarde.

Esta investigación tiene como objetivo demostrar que aquel hecho resultó ser un punto de inflexión en el tratamiento de los desastres naturales en la prensa audiovisual y gráfica. La imagen ganó un peso nunca antes visto, mientras que los periódicos siguieron utilizando los 
esquemas de narración clásicos. Para ello se van a describir y recabar datos cuantitativos de las informaciones que se publicaron en los diarios españoles El País, Abc, La Vanguardia y El Periódico de Catalunya durante aquellos días y se van a comparar con el reportaje que emitió Televisión Española en el programa Informe Semanal titulado "Colombia bajo el volcán".

\section{E1 desastre}

Como ya se ha indicado, el 13 de noviembre de 1985 el volcán erupcionó después de sesenta y nueve años sin registrar actividad alguna formando cuatro lahares o lenguas de lodo y magma. Desde las nueve de la noche había estado lanzando ceniza sin parar, pero las autoridades no decidieron evacuar la zona sino que lanzaron una serie de mensajes por toda la población instando a sus moradores a permanecer en sus casas.

Cuando llegó la noche un apagón repentino sumió a toda la población en la oscuridad más densa. Pocos instantes antes de las 11:30 de la noche la enorme corriente de lodo y magma cubrió Armero volcando automóviles, tirando muros abajo y arrastrando a miles de personas. Tal y como ya se ha mencionado, 25.000 personas murieron de una población de 30.000 habitantes. Los edificios se hundieron aplastando personas y generando escombros que se fueron uniendo a las lenguas de barro y magma. Cerca de 5.000 personas resultaron heridas y 5.000 hogares de trece poblaciones fueron destruidos. Aproximadamente 230.000 personas se vieron afectadas en mayor o menor medida, 20.000 se quedaron sin hogar y un área de $110 \mathrm{~km}^{2}$ quedó arrasada. La tragedia de Armero fue el segundo desastre volcánico más mortífero del siglo XX, superado solo por la erupción del monte Pelée, en Martinica en 1902 y el cuarto más mortífero registrado desde el año 1500. También fue el lahar más mortífero de la historia del que se tenga conocimiento.

Una vez que la lengua destruyó la casa de Omaira, ésta quedó atrapada debajo de los restos de la construcción, con piezas de cemento y restos de diversos tipos impidiéndole moverse. Cuando los equipos de rescate repararon en ella e intentaron liberarla se dieron cuenta de que sus piernas estaban completamente atoradas por culpa de lo que quedó del techo de la casa. Bajo sus pies se encontraba 
también el cadáver de su tía que, si bien impedía que se hundiera, comenzó a descomponerse rápidamente por culpa de la humedad. Según Zeiderman (2009) Omaira estaba atrapada de cuello para arriba, mientras que otros autores como Barragán (1987) aseguran que solo estaba placada de cintura para abajo. Sea como fuere, los rescatadores solo pudieron ver la cabeza de Omaira por encima del nivel del agua en todo momento en que estuvieron a su lado. Un miembro del equipo la descubrió al identificar una mano que se movía entre unos restos. Al retirar esas piezas apareció su cabeza y su drama se hizo público.

Una vez que los socorristas la localizaron trataron de sacarla, pero cuanto más tiraban de ella, más efecto de succión provocaban. Como temían que poco a poco se fuera hundiendo le ataron al poco una cuerda para evitar que se fuera hacia abajo.

La mañana del 15 de noviembre, 35 horas después de que el lahar hubiera pasado por Armero, uno de los socorristas que hacían guardia junto a Omaira llamó la atención del operador de cámara de Televisión Española Evaristo Canete que había sido desplazado al lugar para documentar la tragedia. Canete no lo dudó y grabó su situación y conversó con ella mientras que los socorristas pedían desesperadamente al periodista español que alguien les trajera una motobomba para poder liberar a la niña. En tanto, Omaira pidió decir unas palabras a la cámara, palabras que dieron la vuelta al mundo (Carnel, 2009).

A pesar de su desgracia, Omaira no desfalleció en su ánimo. Además de su breve intercambio de palabras con Canete, accedió a ser entrevistada por un periodista local del diario El Tiempo llamado Germán Santamaría Barragán que se encontraba en el lugar como voluntario. En ocasiones se mostraba animada, en otras aterrada, a veces cantaba y en otras rezaba, pero en la tercera noche de padecimiento comenzó a sufrir alucinaciones, diciendo a sus acompañantes que iba a llegar tarde al colegio o que tenía que estudiar para un examen de matemáticas (AA.VV, 1985).

Cerca del final de su vida, con los ojos enrojecidos, su cara se hinchó y sus manos palidecieron. En un momento dado pidió a los que estaban con ella que se fueran a descansar a sus casas. Horas más 
tarde los socorristas volvieron con una motobomba y trataron de salvarla, pero sus piernas se doblaron bajo el hormigón como si estuviera de rodillas, y era imposible liberarla sin cortar sus piernas. Al carecer del equipo quirúrgico para salvarla de los efectos de una amputación, los médicos presentes estuvieron de acuerdo en que sería más humano dejarla morir. En total, Sánchez sufrió un tormento de 75 horas antes de que diera su último respiro a las 10:05 del 16 de noviembre a causa, muy probablemente, de gangrena o de una hipotermia severa (Lacey, 2010).

Su madre y su hermano sobrevivieron al desastre. "Es horrible, pero debemos pensar en la vida (...) He de vivir por mi hijo que solo ha perdido un dedo" (AA.VV.b, 1985).

En el mismo momento en que la audiencia se enteró de la situación de Omaira a través de los medios de comunicación su muerte se convirtió en un símbolo de otro tipo de desastre: el de la falta de previsión y reacción del Gobierno colombiano ante la calamidad.

\section{Tratamiento en la prensa}

No solo Canete y Santamaría fueron los únicos periodistas que se hicieron eco de la desgracia de Omaira. El fotógrafo francés Frank Fournier también estaba desplegado en Armero para contar al mundo lo que había pasado y tomó la foto de Omaira que dio la vuelta al mundo y simbolizó la tragedia de Armero (Jaccard, 2010).

"La perturbadora imagen, con la que Fournier ganó el World Press Photo en 1986, originó una polémica por la indiferencia del Gobierno con las víctimas y su incapacidad para evitar una tragedia pronosticada. Fournier también fue cuestionado por haber cruzado el límite entre información y el voyerismo."

El periodista galo simboliza el punto de inflexión social entre el tratamiento de la desgracia humana en un hecho narrado informativamente a otro de carácter espectacular. Aunque él no lo hiciera con esa intención, su imagen de Omaira medio hundida entre el fango de Armero, junto con el reportaje de Televisión Española, supuso el comienzo de la ilustración sin tapujos de cualquier hecho 
que conlleve víctimas y sufrimiento humano en los medios de comunicación. Fournier siempre defendió su rol de informador en medio de aquella catástrofe. "Al tomar la fotografía me sentí totalmente impotente, sin poder alguno de ayudarla. Ella enfrentaba la muerte con coraje y dignidad, sentía que su vida se le iba." (Robin, 1999).

Tampoco fue muy consciente de la repercusión de su trabajo, aunque adivinara cierto impacto en el corto plazo porque "hubo mucho escándalo y debates en televisión sobre el papel del fotoperiodista, pero al menos hubo una reacción, hubiera sido peor si a nadie le hubiera importado." (Robin, 1999). Años después se reafirmaría diciendo que "tengo muy claro lo que hago, cómo y por qué lo hago. La foto ayudó a recaudar dinero para ayuda y sirvió para destacar la irresponsabilidad y falta de coraje de los líderes de el país." (AA.VV., 2005). Fournier, que aseguró que "si tuviera que volver a hacerlo todo de nuevo, haría la foto" (AA.VV., 2013) ganó la edición del premio World Press Photo correspondiente a 1986.

Y mientras todo esto ocurría (o más bien, un poco más tarde de que todo esto ocurriera), el diario El País de España publicó su primera crónica sobre Omaira el 17 de noviembre, cuatro días después de que el volcán hubiera erupcionado.

En todos los años que han pasado desde el hecho, este diario tan solo ha publicado algún tipo de información sobre la protagonista de este estudio en cinco ocasiones. La primera fue en una crónica de Ramón Gorriarán (1985) en la da cuenta de todo el periplo de la niña, desde que fue encontrada por el rescatador hasta que "cuando, por fin, fue sacada, ya estaba muerta". A partir de este momento, con el fenómeno televisivo en plena ebullición, el enviado a Colombia publicó una nueva crónica sobre Omaira al día siguiente y no es hasta el 23 de noviembre cuando un ciudadano publica una carta al director mencionando a la niña (Adams, 1985). En los meses siguientes solo se menciona a Omaira en una noticia de agencia sobre el World Press Photo y la instantánea de Fournier.

Sin embargo en 2012, con motivo de un aniversario de la tragedia, el mismo medio volvió a publicar su nombre dentro de un reportaje sobre fotorreporteros (Lagoa, 2012). 
El diario $A b c$, ya sea en su edición de Madrid como la de Sevilla aún incluso tardó más que El País en nombrar a Omaira en sus informaciones. En este caso no fue hasta el día 18 de noviembre cuando por primera vez apareció la niña y su drama mencionado, curiosamente, en un pie de foto de su edición de Sevilla. Así ocurrió durante dos días consecutivos y en el mismo formato de imagen.

El 31 de noviembre una noticia titulada "Católicos belgas propusieron la beatificación de Omayra Sánchez" y firmada por una agencia vuelve a colocar a la niña colombiana en el punto de mira informativo. El 26 de diciembre, también de agencia, se publica una información sobre unos supervivientes de la tragedia y el 31 de diciembre, dentro del resumen del año, vuelve a aparecer su foto publicada. Ese mismo día se la menciona en el editorial de la publicación.

Pocos meses después, ya en 1986, en la columna de opinión de José María Requena (1986) titulada "Testigos de la historia" se afirma que "aún están por medir los cambios que podido experimentar el hombre de hoy día al sentirse testigo ocular de hechos que hicieron historia" en alusión, entre otros, de Omaira y su exhibición televisiva.

$\mathrm{Y}$, a pesar de haber usado su imagen más que su crónica del suceso entre sus páginas, en diario $A b c$ ha sido el que más veces ha nombrado a Omaira en sus informaciones. Entre el 6 de febrero de 1986 y el 21 de junio de 2010 ha aparecido en catorce ocasiones, la gran mayoría de las veces como mero recurso de relación conceptual o textual, pero en todas como imagen icónica de los desastres naturales en general.

En Barcelona, el diario La Vanguardia tampoco mencionó a Omaira hasta el día 17 de noviembre, el mismo día que sus colegas de Madrid de El País. Teniendo en cuenta las limitaciones de comunicación que existían en aquel momento y que no se pueden comparar con las redes que existen hoy, es hasta vanagloriable que las primeras apariciones de Omaira en la prensa escrita nacional no fueran hasta esa fecha. El periodista Joaquim Ibarz (1985: 5) asegura en su crónica que "este salvamento imposible ha sido un doble símbolo de la tragedia, tanto por el interés ciudadano ante una niña que mostraba 
gran entereza como por las deficiencias evidenciadas en las tareas de rescate”.

A partir de aquí, Omaira aparece mencionada de forma indirecta en dos noticias durante el resto del año 1985, en cuatro de 1986 y en una de 1987. No es hasta 2005 en que Jordi Rovira (2005: 12) la rescata del olvido en su semblanza titulada "Veinte años sin Omayra" publicada en el suplemento dominical.

El Periódico de Catalunya publicó catorce noticias sobre Omaira con ella como protagonista o como segundo plano informativo entre $1985 \mathrm{y}$ 2008. La primera noticia tiene fecha del 19 de noviembre de 1985 y no es hasta casi un mes y medio después, ya en enero de 1986, cuando vuelve a ser mentada. Entre los años 1986 y 1987 se concentra el mayor número de informaciones acerca de la niña, tema que desaparece de la cabecera hasta 1990 en que vuelve a aparecer. El resto de apariciones es esporádico y puntual, tanto que en 18 años solo se vuelve a hablar de ella en cinco ocasiones.

\section{Tratamiento del hecho en Televisión Española}

Mientras que Fournier ha dado la vuelta al mundo contando su hazaña y recibiendo premios, el otro gran protagonista de esta historia, el operador de cámara español Evaristo Canete, raramente suelta por su boca algún dato ilustrativo de aquel desastre. Canete se encontraba en Colombia en la corresponsalía en Bogotá informando de los recientes sucesos del asalto perpetrado el miércoles 6 de noviembre de 1985 por un comando de guerrilleros del Movimiento 19 de abril (M-19) a la sede del Palacio de Justicia. Cuando el equipo de TVE llega a Armero, lo que se encuentran es un espacio vacío donde antes de erigía una cuidad del tamaño de Teruel con barro por todas partes, miles de heridos, socorristas desesperados porque no tienen medios y una sensación de caos importante.

Cuando el miembro del equipo de salvamento llama a Canete y éste comienza a grabar la escena, lo que no sabe el reportero español es que su trabajo va a tener un efecto de impacto mundial casi instantáneo. (Monegal, 2010): 
"Por primera vez, la tele retransmitió una agonía en directo, y no con final feliz, sino de muerte, que es el colofón ideal para provocar un buen impacto en la audiencia. A partir del caso Omaira la tele cambió el modo de enfocar los sucesos. Y en una enfermiza búsqueda, se ha intentado reproducir el modelo, buscando -muchas veces fabricandomás Omairas constantemente."

El trabajo de Canete, miembro de un equipo extranjero de una televisión pública que en aquellos momentos tiene muy claro que su función es la de informar y formar a la audiencia como servicio público de calidad, sirvió de espoleta para transformar el tratamiento audiovisual hecho hasta ese momento en beneficio de otros intereses (Monegal, 2010):

"Los grandes pájaros que diseñan el modo, la manera de informar desde la televisión, comprendieron entonces, enseguida, que lo ideal para conseguir audiencias fabulosas no era tanto enseñar una muerte, sino mostrar la agonía del ser humano hasta llegar a ella."

"Colombia: bajo el volcán" se emitió en Informe Semanal el 11 de enero de 1986 y obtuvo el premio Ondas en la categoría de mejor reportaje internacional de televisión en la edición de ese mismo año.

Omaira, tras más de 60 horas de agonía, abre el reportaje con un total estremecedor en el que habla a su madre y le pide que rece por ella mientras le dice "adiós". Tras ello, las primeras palabras en off de la corresponsal en Centroamérica de TVE en aquel tiempo, Ana Cristina Navarro, apuntan directamente a una negligencia del gobierno colombiano en la gestión de la erupción como culpable de la gran magnitud de la catástrofe. De hecho, se menciona hasta en dos ocasiones que si la radio y el párroco de la ciudad no hubieran aconsejado a la población a quedarse en sus casas tras la lluvia de cenizas que cayó la tarde antes del suceso, el número de víctimas no hubiera sido tan elevado con gran probabilidad.

El reportaje dura 17 minutos y 46 segundos. En el minuto 5:40 la reportera cambia el guión y mete un punto de giro diciendo "nuestras palabras están de más en esta narración” (Navarro, 1985). A partir de aquí se suceden las imágenes con sonido ambiente de los supervivientes, los heridos, las colas para registrar a los desaparecidos, 
las salas de la morgue llena de cadáveres y los totales con declaraciones de afectados y médicos. Todo sin off, al estilo "No comment" de Euronews, dando la mayor importancia que se puede dar a la narración audiovisual que es dejar que se explique un hecho sin necesidad de ningún apoyo verbal, con todo el peso recayendo sobre la imagen y su montaje.

Y así, en el minuto 8:20 aparece Omaira. "Yo vivo porque tengo que vivir. Y apenas tengo trece años", dice en un primerísimo primer plano conseguido por Canete con la cámara al hombro. La narración sigue sin off. En el ambiente se cuela la explicación de la situación de Omaira hecha por un rescatador de la Cruz Roja Colombiana que está junto a ella impotente. En un momento dado se oye al propio operador de cámara hablar con la niña, traspasando esa frontera de la frialdad profesional a la del sentido humano (al fin y al cabo) del que capta las imágenes que, no se ha de olvidar, también es humano.

La narración continúa con un contrapunto. Tras Omaira se muestra un bebé que acaba de nacer y a quien su madre ha llamado Consuelo. Los miembros del equipo de rescate deciden, con la cámara grabándoles delante, que aquel campo de aterrizaje de helicópteros improvisado se llamará Consuelo en honor a la recién nacida. De nuevo, el operador de cámara habla a los protagonistas.

Y así continúa el reportaje, sin off, mostrando los desastres dejados atrás por los lahares de lodo con dramas personales aquí y allá. En el minuto 15:24 vuelve a surgir la voz de la reportera, con la imagen de un desvencijado Renault 12 con la identificación de TVE en el parabrisas haciendo patinaje sobre el barro.

Los cuarenta segundos finales del reportaje son, de nuevo, para Omaira. Con sonido de ambiente, otra vez, se ve a un equipo numeroso de personas tratando de sacarla de su cautiverio. Un rótulo anuncia, al final del todo que "Omaira ha fallecido hoy a las seis de la tarde" mientras se la ve a ella diciendo "quiero que la cámara me tome saliendo de aquí triunfante" (Navarro, 1985).

De los casi 18 minutos que dura todo el reportaje, Omaira es protagonista de tan solo tres. Tres minutos que significan un 16,67\% de todo el metraje lo que no es una cantidad muy significativa y más 
teniendo en cuenta que el reportaje se identifica con Omaira claramente.

La relación mental entre Omaira y todo el resultado viene dado por la colocación de las piezas clave. Omaira abre el reportaje con sus palabras. Ocupa el momento central de toda la puesta en escena cuando Canete la encuentra en medio del desastre y habla con el rescatador. Y cierra la narración con el desenlace dramático del intento infructuoso de sacarla de su cautiverio con sus palabras de esperanza. Palabras que quedan en una macabra paradoja cuando se atisba el rótulo final anunciando su muerte.

\section{Conclusiones}

Tras haber analizado los contenidos de las coberturas informativas que tuvo el evento, ya sea por parte de la prensa escrita de España como de la única cadena de televisión que existía en aquel momento, podemos decir que la imagen ganó la partida a la narración textual y supuso un punto de inflexión en el tratamiento que se hizo a partir de aquel momento a los desastres naturales en los que ha habido pérdidas humanas.

Como se ha podido ver, tres periodistas acompañaron a Omaira durante su agonía: uno de prensa escrita, otro de televisión y otro del mundo de reporterismo gráfico. De los tres, el fotógrafo francés Fournier fue el que más vio reconocido su trabajo con diversos premios internacionales. Evaristo Canete obtuvo un premio prestigioso en España y, aunque sus imágenes dieron la vuelta al mundo y abrieron innumerables informativos, la globalización de la imagen tenía mucho más peso en 1986 en el mundo de la fotografía que en la de la televisión. El medio televisivo aún no había experimentado un desarrollo de intercomunicación global tal y como el que tenemos hoy día y la cobertura informativa visual era mucho más amplia en el mudno de las revistas que en el de la televisión. De ahí la limitada repercusión iconográfica televisiva de la imagen de Omaira hablando a la cámara despidiéndose de su madre frente a la fría fotografía de la niña con los ojos inyectados en sangre y con la mano completamente lívida. 
Por su parte, el periodista colombiano Santamaría de El Tiempo obtuvo su reconocimiento en su país de origen, donde en aquel momento la prensa escrita y radiofónica dominaban la esfera periodística nacional. Su periódico y Radio Caracol fueron los medios que más atención pusieron en el desastre y los que mayor repercusión obtuvieron en detrimento de la televisión que, por aquel entonces, no tenía el desarrollo ni la penetración de hoy.

Por tanto, cada uno de ellos simboliza el poder del vehículo de transmisión del tipo de medio para el que trabajaban en aquellos días. Con respecto a España, como fue un operador de cámara de TVE el que ilustró el caso de Omaira en primera persona, fue la televisión la que impactó en el subconsciente colectivo y la imagen gráfica sirvió de complemento y asentador complementario del audiovisual. El drama humano se sintió en primera persona en cada conciencia. La imagen se coló en la retina de la audiencia y un hecho, acontecido a miles de kilómetros, se convirtió en cercano. Los protagonistas no se limitaron a ser víctimas que engrosaban una lista numérica de afectados sino que mostraron su cara y dejaron oír sus lamentos, sus quejas ante el Gobierno y su rabia. Mientras, en la prensa escrita, el hecho fue tratado como una erupción más, describiendo y analizando los mismos eventos desde un punto de vista formal, ilustrativo y descriptivo, pero sin lograr conectar con el público de la misma forma que el poder de la imagen puede hacerlo.

El desastre de Armero y dramático caso de Omaira llegó a la opinión pública mundial por medio de la imagen y del sonido de forma mucho más rápida y completa que de la escrita. El desarrollo tecnológico de las medios audiovisuales vivió su punto de no retorno en la carrera contra los periódicos en aquel momento. Desde aquel día la evolución informativa audiovisual no ha hecho más que avanzar y la forma de contar los sucesos de la prensa escrita ha tenido que adaptarse a este nuevo escenario. La inmediatez del escrito se ha reducido gracias a internet. La prensa aún impresa en papel ha incorporado gráficos, fotografías en color y otros nuevos recursos visuales porque la audiencia ha pedido desde aquel momento y sigue pidiendo una información de calidad en un entorno gráfico accesible.

Los desastres naturales, tan profusos en historias dramáticas y tan tratadas como gancho de audiencia ya no se cuentan en los periódicos 
como una mera narración de los hechos, sino que llenan sus páginas de imágenes y fotografías. Los medios audiovisuales, por su parte, han ido evolucionando en la línea marcada por la experiencia de Colombia en 1985. Si en aquella ocasión el mundo tuvo que esperar para ver en profundidad qué había pasado en Armero (Informe Semanal emitió el reportaje un mes después de la erupción), hoy día se emite en directo cualquier acontecimiento sea de la índole que sea.

Aparte queda la ética con la que esos dramas humanos son mostrados en la pantalla en un espectáculo en el que sus protagonistas no quieren participar. El público está ávido de sangre desde tiempos de los romanos y la arena actual tiene forma de multipantalla. El desarrollo vivido desde Omaira ha traído tras de sí muchas otras Omairas que han desfilado por la arena y hasta la prensa escrita, que por aquel entonces no bajaba a las catacumbas, también ha terminado sucumbiendo a los dominios del drama humano como espectáculo.

\section{Referencias bibliográficas}

AA.VV. (2013): "Omayra, aux yeux du monde" en Service Photo, Liberation, París, 22 de julio: http://www.liberation.fr/culture/2013/07/22/omayra-auxyeux-du-monde_920014 (consultado el 11 de agosto de 2014)

AA.VV. (2005): "La historia de la foto de Omayra" en BBC News Online, Londres, 3 de octubre:

http://news.bbc.co.uk/hi/spanish/misc/newsid_4305000/4305372.stm (consultado el 1 de agosto de 2014)

AA.VV. (1985): "Volcano kills thousands in Colombia" en BBC News Online, Londres, 13 de noviembre:

http://news.bbc.co.uk/onthisday/hi/dates/stories/november/13/newsid_253 9000/2539731.stm (Consultado el 21 de septiembre de 2014)

AA.VV.b. (1985): “Ordeal ends in death" en The Leader Post. Regina, 18 de noviembre:

http:// news.google.com/newspapers?id=TX5WAAAAIBAJ\&sjid=QEENAA AAIBAJ\&pg=3684,440325 (Consultado el 12 de septiembre de 2014)

Adams, M. (1985): “Omayra Sánchez” en El País. Madrid, 23 de noviembre: http://elpais.com/diario/1985/11/23/opinion/501548403_850215.html (Consultado el 4 de octubre de 2014) 
Carnel, J.S. (2009): “Le regard qui traumatisa la télévision", en Communication \& langages, $\mathrm{n}^{\circ}$ 161. Ámsterdam. pp. 5-20.

Santamaría, G. (1987): Colombia y Otras Sangres. Austin: University of Texas.

Belver, M. (2012): "La huella devastadora del Nevado del Ruiz" en El Mundo.

Madrid, 26 de junio: http://www.elmundo.es/blogs/elmundo/rutaquetzal/2012/06/26/la-huella-devastadora-del-nevado-ruiz.html (Consultado el 1 de septiembre de 2014)

Gorriarán, R. (1985): "La larga agonía de Omayra Sánchez" en El País. Madrid, 17 de noviembre:

http://elpais.com/diario/1985/11/17/internacional/501030013_850215.html (Consultado el 7 de octubre de 2014)

Lacey, D. (2010): "Why we don't cover Pakistan" en The Canadian Journalism Project. Toronto, 31 de agosto: http://j-source.ca/article/why-we-dont-coverpakistan (Consultado el 22 de octubre de 2014)

Lagoa, M. (2012): “Cámaras en primer plano” en El País. Madrid, 31 de octubre:

http://cultura.elpais.com/cultura/2012/01/30/television/1327941724 115167 htm (Consultado el 1 de septiembre de 2014)

Monegal, F. (2010): “Omaira, sin saberlo, cambió la tele" en El Periódico de Catalunya. Barcelona, 16 de noviembre:

http://www.elperiodico.com/es/noticias/tele/omaira-sin-saberlo-cambio-tele589945 (Consultado el 1 de septiembre de 2014)

Ibarz, J. (1985): “Colombia: más de veintidós mil muertos, nueva cifra oficial de la catástrofe del Nevado Ruiz" en La Vanguardia. Barcelona, 17 de noviembre: http://hemeroteca.lavanguardia.com/preview/1986/07/07/pagina5/32862293/pdf.html?search=omayra (Consultado el 14 de octubre de 2014)

Jaccard, N. (2010): "Armero y Omayra: "Los años pasan y nada se borra" en Semana.com. Bogotá, 9 de noviembre:

http://www.semana.com/nacion/articulo/armero-omayra-los-anos-pasannada-borra/124350-3 (Consultado el 14 de septiembre de 2014)

Navarro, A. C. (1985): Colombia: bajo el volcán [Vídeo]. Disponible en: http://www.rtve.es/alacarta/videos/informe-semanal/informe-semanalcolombia-bajo-volcan/600399/ (Consultado el 3 de agosto de 2014)

Requena, J. M. (1986): "Testigos de la historia" en $A B C$. Sevilla, 5 de febrero: http://hemeroteca.abc.es/nav/Navigate.exe/hemeroteca/sevilla/abc.sevilla/19 86/02/05/010.html

Robina, M. M. (1999): Les 100 photos du siècle. París: Éditions du Chêne 
Rovira, J. (2005): "Veinte años sin Omayra" en La Vanguardia. Barcelona, 13 de noviembre:

http://hemeroteca.lavanguardia.com/preview/2005/11/13/pagina-

12/43157580/pdf.html?search=omayra (Consultado el 7 de septiembre de 2014)

Zeiderman, A. (2009): "Life at Risk: Biopolitics, Citizenship, and Security in Colombia" en AA.VV., American Ethnologist. Nueva York: AES. 



\title{
Comunicación de crisis y lenguaje: la erupción submarina en la Isla de El Hierro
}

\author{
Araceli Álvarez Díaz, Universidad de La Laguna, \\ aracelitfe@,terra.com
}

Resumen: La erupción volcánica submarina ocurrida en la isla canaria de El Hierro en octubre de 2011 generó un gran volumen de información tanto en la prensa de las islas como en los periódicos nacionales. La alarma se desató en la población de la isla ante un fenómeno que produjo movimientos sísmicos y que afectó a la economía de la misma, dado que, durante mucho tiempo la zona de La Restinga, una de las más turísticas, tuvo prohibida la visita de turistas. Además, la pesca submarina, uno de los mayores atractivos de la isla, se vio seriamente afectada. El estudio pretende determinar si las informaciones publicadas entre octubre de 2011 y octubre de 2012 en las ediciones digitales de los periódicos canarios El Día y Canarias 7 y los nacionales El País y El Mundo fomentaron la alarma entre la población y si se ofreció información de calidad respaldada por expertos en la materia. Para ello se prestará especial atención al lenguaje utilizado en los titulares en los que se ha señalado palabras clave que generan sensación de alarma o que subrayan aspectos sensacionalistas.

Palabras clave: Comunicación de crisis; riesgos; alarma social; medio ambiente; volcanismo. 


\section{Introducción}

L

A ERUPCIÓN volcánica que se produjo en la isla canaria de El Hierro en el mes de octubre de 2011, tras una sucesión de movimientos sísmicos que se iniciaron en julio de dicho año, provocó un revuelo en la isla ya que tuvo repercusiones sociales, económicas y políticas en un espacio que cuenta con un importante patrimonio natural y medioambiental. En una situación de crisis ${ }^{4}$ como esta, los medios de comunicación constituyen un factor importante a la hora de transmitir las informaciones que se van generando sobre el fenómeno volcánico. Las repercusiones sobre el turismo y sobre las

4 La Organización Panamericana de la Salud realiza una serie de recomendaciones que deben tenerse en cuenta para lograr una comunicación de éxito con la población en situaciones de crisis.

* Los medios de comunicación de masas necesitan de información entregada a tiempo, actualizada y transparente, que incluya declaraciones de los voceros con la posición oficial sobre la situación, imágenes, cifras, testimonios e información sobre las actividades concretas que tiene que realizar la población para proteger su salud.

* Es importante generar confianza y prever las solicitudes de información que harán los medios. Es necesario preparar información clara y oportuna, que tenga en consideración las preocupaciones y los intereses de la población, acerca de la situación de la emergencia, de las medidas que se adoptan para controlarla y de la forma en que la ciudadanía puede cooperar con dichas medidas.

* Asimismo, es importante saber diferenciar la información de acuerdo a las características de los medios; en este sentido, los medios televisivos necesitan imágenes, relatos de la vida real, mientras que los medios escritos podrán profundizar mucho más en la publicación de datos y otras informaciones que el público leerá con más detenimiento.

* Las autoridades a cargo de la emergencia deberán contar con profesionales que atiendan directamente a los periodistas, respeten su profesionalidad y eviten divulgar información improvisada sin fundamento o basada en conjeturas.

* Es necesario mantener la comunicación regular con los medios de comunicación y no únicamente cuando se les necesita; para ello, es vital forjar alianzas con los medios en insertar en su agenda informativa temas relacionados con los riesgos y las medidas para proteger la salud de la población.

* La elaboración de un plan de medios, que forma parte integral de la estrategia de comunicación de riesgos, es una herramienta que ayuda a agilizar la respuesta proactiva y eficaz al inicio de una emergencia. 
principales actividades que se desarrollan en El Hierro y, concretamente en la zona de La Restinga, -la pesca y el buceo-, fueron muy importantes. De hecho, esta área donde surgió el volcán, es un polo económico clave ya que es un espacio de pesca y turístico destacado en la isla. Este fenómeno hizo, además, que parte de la población emigrara a otras islas en busca de una alternativa para subsistir. En el presente trabajo se ha estudiado las informaciones publicadas en el período de un año, que se inicia en octubre de 2011 cuando se produce la erupción volcánica y culmina en octubre de 2012, en las ediciones digitales de los periódicos canarios El Día y Canarias 7, uno de Tenerife y otro de Gran Canaria, así como de los nacionales El País y El Mundo.

\section{Objetivos}

El objetivo general del presente trabajo es analizar las informaciones aparecidas en el período anteriormente señalado para conocer e identificar cuáles son las claves con las que se transmite la información sobre este fenómeno. Los objetivos específicos serían los siguientes:

-Definir el nivel de presencia de manifestaciones de expertos en la materia en las informaciones publicadas frente a las provenientes de las fuentes institucionales.

-Establecer qué porcentaje de informaciones se centra en el fenómeno eruptivo en contraposición a las que se dedican a los daños colaterales, -económicos, sobre la salud-, que genera dicho proceso.

-Determinar qué porcentaje de los titulares que encabezan las informaciones genera alarma o por el contrario fomenta la tranquilidad entre la población.

\section{Metodología}

El análisis se centra, por un lado, en identificar y cuantificar el número y tipo de fuentes utilizadas en la construcción de los mensajes publicados por estos diarios para determinar cuáles son las 
que tienen mayor peso o si, por el contrario, hay un equilibrio entre las fuentes científicas y las institucionales ${ }^{5}$.

Asimismo se prestará especial atención al lenguaje utilizado en los titulares. En este sentido, en función de unos marcadores definidos se trata de concluir si los titulares transmiten alarma o si, por el contrario, contribuyen a tranquilizar a la población afectada. La comunicación de crisis en un fenómeno eruptivo de estas características resulta compleja ya que hay varios interlocutores de carácter institucional con ámbitos competenciales distintos actuando a la vez. Por otro lado, estaría la opinión de los expertos vinculados a organismos y entidades especializadas en este tema. Hay que tener en cuenta, además, que, durante el período que dura este fenómeno, medios de comunicación de todo el mundo se interesaron por el evento que fue cubierto por corresponsales y enviados especiales.

\section{Análisis}

\subsection{Antecedentes}

Los movimientos sísmicos que derivaron en la erupción volcánica submarina de la isla de El Hierro se iniciaron el 19 de julio de 2011, momento en el que se registraron los primeros seísmos en el municipio de Frontera, según informó el Instituto Geográfico Nacional (IGN). El 10 de octubre de ese año se produjo la mencionada erupción a unos cinco kilómetros de La Restinga y a unos 1.000 metros de profundidad, en el Mar de Las Calmas. Al día

\footnotetext{
${ }^{5}$ La estrategia de comunicación seguida por la Dirección General de Seguridad y Emergencias del Gobierno de Canarias, organismo del que depende el Plan Especial de Protección Civil y Atención de Emergencias por Riesgo Volcánico (Pevolca), que a su vez cuenta con un comité científico, en un intento de controlar y canalizar la información, se basó en transmitir las conclusiones de los científicos integrantes de dicho organismo que estudiaban el proceso a través de comunicados oficiales y de ruedas de prensa a cuyo frente se encontraba normalmente el responsable de dicha Dirección General, Juan Manuel Santana, así como, en muchas ocasiones, la directora del Instituto Geográfico Nacional (IGN) en Canarias, María José Blanco. Además otros organismos científicos participantes en el proceso, como el Involcan o el Iter, hacían llegar sus análisis y estudios al Comité Científico del Pevolca que después los daba a conocer.
} 
siguiente se decretó el nivel rojo de riesgo volcánico y se ordenó la evacuación del pueblo de La Restinga. Se trata de la primera erupción en territorio nacional desde que, en 1971, se produjera la del volcán Teneguía en La Palma. El proceso eruptivo se desarrolló desde ese momento, y el día 5 de marzo de 2012, los científicos lo dieron por concluido aunque tuvo manifestaciones posteriores.

El día en el que se produjo la erupción, Canarias 7 publicó la siguiente información titulada "Cuatro barcos informan de una erupción al sur de La Restinga"; El Mundo publicó dos informaciones tituladas "El Hierro registra una erupción submarina a 5 kilómetros de la costa" y "La erupción en El Hierro, un espectáculo submarino imposible de observar"; por su parte, El País se hizo eco por primera vez de la noticia el día 11 de octubre de 2011 y tituló: "La erupción volcánica submarina de El Hierro libera magma y gases en el océano". Finalmente, El Día publicó en esa misma fecha la primera de una serie de informaciones titulada "Los volcanólogos confirman una erupción submarina al sur de El Hierro".

A partir de ese momento, el fenómeno eruptivo se sucede y va cobrando cada vez más importancia. A la isla de El Hierro se desplazaron científicos y especialistas de distintas instituciones para estudiar el proceso volcánico.

\subsection{Análisis: E1 Día}

El periódico El Día publicó un total de 266 informaciones durante el período de estudio de este trabajo. El día siguiente a que se produjera la erupción, este diario publicó 7 informaciones relativas al proceso eruptivo con los siguientes titulares: "Los vulcanólogos confirman una erupción submarina al sur de El Hierro"; "El proceso eruptivo comienza dos días después del terremoto de mayor fuerza"; "La tierra palpita a cinco kilómetros de la costa y a uno de profundidad"; "Elevan a semáforo rojo el riesgo volcánico en la zona de La Restinga(El Hierro); "El Colegio de Geólogos duda de que se haya registrado una erupción volcánica en El Hierro y descartan un tsunami"; "Estamos ante el posible nacimiento de un volcán, dice la Red Sísmica” y "La última erupción volcánica en España se produjo 
en 1971". A lo largo del período estudiado, este medio publicó 5 entrevistas: los días 9/07/12, a María José Blanco, directora del IGN en Canarias; 11/11/11, al geólogo Juan Jesús Coello; 26/10/11, a Juan Carlos Carracedo; 04/12/11, al Director General de Seguridad y Emergencias del Gobierno de Canarias, y 4/08/12, a Antonio Darwich, profesor de la ULL.

Llama la atención que, en varias ocasiones, se publicaron textos repetidos y dentro de una misma información se repitieron otras ya publicadas anteriormente; algunas veces relacionadas y otras no. Dicha circunstancia se produce 14 veces. Si bien en algunos casos se puede justificar que haya algún párrafo o parte de un texto que se repita por su relevancia, no es lógico que haya informaciones en las que se mezclen noticias que ya se han publicado anteriormente y que son de distinta temática separadas por un ladillo, o que, simplemente, se cambie el titular y se repita el mismo texto que ya se ha dado.

"En los acontecimientos que generan alarma o agitación social, los públicos esperan comportamientos que transmitan seguridad y contenidos de utilidad que puedan considerarse referenciales ya que la necesidad de información aumenta la proliferación y la credibilidad de los contenidos que circulan por los canales informales (rumores) y fomenta la proactividad de los individuos en el uso de recursos que permitan divulgar su conocimiento y su sentimiento sobre el asunto." Túñez García (2012: 6).

Por lo que respecta a los temas tratados, si bien es cierto que la mayor parte de las notas, un total de 203, lo que representa un 76.3 por ciento, se dedica a narran el discurrir del proceso eruptivo, también se da cobertura a otros asuntos colaterales. En cuanto al bloque de informaciones que se destina a cuestiones estrictamente económicas, la cifra asciende a un total de 32 , lo que supone un 12 por ciento del total, mientras que en otras 22 , un 8.2 por ciento, se hace referencia a las consecuencias económicas de dicho fenómeno, lo que supone que, en un 20.3 por ciento de las notas, se alude a temas económicos.

En cuanto a las posibles consecuencias sobre la salud de los habitantes de la isla, en 9 informaciones se hace referencia a este problema, lo que supone un porcentaje del 3.3\%. 
Sobre las fuentes consultadas para la elaboración de las notas, las correspondientes al ámbito científico son: el Instituto Geográfico Nacional, a través de su directora en Canarias, María José Blanco, de Carmen López, de su página web y de su Red de vigilancia; el Centro Superior de Investigaciones Científicas (CSIC), a través de Joan Martí, de Ramón Ortiz, y de Alicia García; el Instituto Español de Oceanografía (IEO), a través de Eugenio Fraile, de los jefes de Flota, Luis Gago y José Ignacio Díaz, del investigador Jesús Rivero y del subdirector del Centro Oceanográfico de Canarias, Demetrio Armas; el Instituto Volcanológico de Canarias (Involcan), a través de su coordinador, Nemesio Pérez, de su canal youtube y de su página de Facebook; los vulcanólogos Juan Carlos Carracedo y Francisco Sánchez; científicos de la Universidad de Cádiz; los profesores de la ULL Alberto Brito, José Antonio Rodríguez Losada y Antonio Darwich; así como geólogos de la Universidad de Barcelona; el vicepresidente del Colegio Oficial de Geólogos, José Luis Barrera; el investigador del Banco Español de Algas, Iván Alonso; el ITER; el profesor de la facultad de Ciencias del Mar de la ULPGC, Antonio González; el vulcanólogo de la UNAM, Servando de la Cruz; la Agencia Espacial Europea; el grupo Bioecomar de la ULL; el Museo de Ciencias Naturales a través de su web; la revista Scientific Reports; Kenji Nogami, catedrático del Instituto Tecnológico de Tokio, y la Universidad de Cantabria.

\begin{tabular}{|l|l|l|}
\hline Fuentes Científicas & $\begin{array}{l}\mathbf{N}^{\mathbf{o}} \text { Informaciones en las que se } \\
\text { les cita }\end{array}$ & Porcentaje \\
\hline Instituto Geográfico Nacional & 53 & 19.9 \\
\hline Instituto Español de Oceanografía & 13 & 4.5 \\
\hline $\begin{array}{l}\text { Consejo Superior de Investigaciones } \\
\text { Científicas }\end{array}$ & 9 & 3.3 \\
\hline Involcan/ Nemesio Pérez & 12 & 4.5 \\
\hline $\begin{array}{l}\text { Expertos/instituciones científicas en } \\
\text { general }\end{array}$ & 28 & 10.5 \\
\hline
\end{tabular}

En cuanto a las fuentes institucionales, las referidas en las notas son las siguientes: el Cabildo de El Hierro, a través de su presidente, y de las consejeras de Seguridad y de Turismo; el Ministerio del Interior, a 
través del Subsecretario del Interior; el Ministerio de Ciencia e Innovación; el ministro de Fomento y portavoz del Gobierno, José Blanco; el Secretario de Estado, Gaspar Zarrías; la delegada del Gobierno en Canarias; el subdelegado del Gobierno en Santa Cruz de Tenerife; Salvamento Marítimo; el Gobierno de Canarias, a través de su presidente, Paulino Rivero, y de su vicepresidente, José Miguel Pérez, respectivamente; la Dirección General de Seguridad y Emergencias y su organismo delegado, el Plan Especial de Protección Civil y Atención de Emergencias por Riesgo Volcánico (Pevolca); el Director General de Comercio y Consumo, Gustavo Matos; la Consejería de Economía, Hacienda y Seguridad; la Consejería de Sanidad, el viceconsejero de Turismo, Ricardo Fernández de la Puente; el viceconsejero de Acción Exterior, Cándido Padrón; el portavoz del ejecutivo, Martín Marrero; el Cabildo de Tenerife y su presidente; Protección Civil; los alcaldes de El Pinar y Frontera, así como la concejal de Turismo de El Pinar; el presidente de la Federación Canaria de Municipios; el concejal de Cultura del Ayuntamiento de La Orotava y la Unidad Militar de Emergencias.

\begin{tabular}{|l|l|l|}
\hline Fuentes Institucionales & $\begin{array}{l}\mathbf{N}^{\mathbf{o}} \text { informaciones en las que se les } \\
\text { cita }\end{array}$ & Porcentaje \\
\hline $\begin{array}{l}\text { Gobierno de Canarias(varios } \\
\text { departamentos) }\end{array}$ & 56 & 21 \\
\hline $\begin{array}{l}\text { Director General de Seguridad } \\
\text { y Emergencias/PEVOLCA }\end{array}$ & 67 & 25.1 \\
\hline Cabildo de El Hierro & 29 & 10.9 \\
\hline $\begin{array}{l}\text { Gobierno central(varios } \\
\text { departamentos) }\end{array}$ & 9 & 3.3 \\
\hline Ayuntamientos de El Hierro & 6 & 2.2 \\
\hline
\end{tabular}

En las situaciones de crisis, desde la psicología comunitaria se plantea que, cuando hay incertidumbre, la percepción de control aumenta si se dispone de información. Esto predispone a los líderes, tanto personales como organizacionales, a aumentar la cantidad de información de utilidad que distribuyen para mantenerse o consolidarse como tales líderes. 
Otras fuentes citadas son: la Asociación de Pequeña y Mediana Empresa (Apyme), el vicepresidente de Binter, el dueño del club de buceo de La Restinga, Iñaki Cañón, CajaSiete, el presidente de la Cofradía de pescadores de La Restinga, la Caja de Canarias, la organización ecologista Oceana, el presidente de la Asociación Hotelera y Extrahotelera de Tenerife, La Palma, La Gomera y El Hierro (Ashotel), pescadores y vecinos.

Llama la atención una información fechada el 18 de octubre titulada "Denuncian ante la Fiscalía que el túnel de La Frontera no cumple la normativa" sobre la denuncia presentada por un herreño llamado Pedro Casañas.

También se cita medios de comunicación como la agencia Efe/Efeverde, Europa Press, la Televisión Canaria, Canarias 7 y prensa extranjera como The Washington Post, La Republicca y Der Spiegel.

\subsection{Análisis: Canarias 7}

El periódico Canarias 7 prestó una muy escasa cobertura al suceso ya que publicó tan solo 5 informaciones en el período estudiado. El día en que se produjo la erupción, este diario tituló "Cuatro barcos informan de una erupción al sur de La Restinga". No hay una sola entrevista en todo el período. Por lo que respecta a los temas tratados, la totalidad de las notas publicadas se refiere al proceso eruptivo; no se hace mención a los temas colaterales como la crisis económica o las afecciones sobre la salud. Las fuentes utilizadas para la elaboración de los mensajes son: la Agencia Efe, el Involcan, el Director General de Seguridad y Emergencias del Gobierno de Canarias, Juan Manuel Santana y la directora del IGN en Canarias, María José Blanco.

\subsection{Análisis: E1 País}

El periódico El País publicó un total de 59 informaciones en el período analizado. En cuanto a los temas abordados, cuatro de ellas se dedicaron exclusivamente a tratar las consecuencias económicas que tuvo la erupción para la isla y se presentaron con los siguientes 
titulares: "El Hierro: 100 días de volcán y de ruina económica para la isla"(19/01/2012); "El Hierro: una economía hundida por el volcán"(9/01/2012); "La erupción golpea la economía de El Hierro"(14/10/2011) y "El Gobierno canario aprueba ayudas de emergencia para los vecinos de La Restinga"(10/11/2011). Esto supone que un 6.7 por ciento de las informaciones estuvo centrado en la crisis económica que vivió la isla paralelamente al fenómeno natural, aunque en buena parte del resto de noticias publicadas, en total 21 , lo que supone un 38 por ciento, hay referencias a dicha crisis. Los textos describen una situación catastrófica para la economía de la isla que incide sobre todo en el sector turístico, con un descenso del 70 por ciento en el número de visitantes, lo que conllevó el cierre de muchos restaurantes, alojamientos y negocios, en general. Todo ello derivó en la declaración de "emergencia social" por parte de los tres municipios afectados. Pero, además del turismo, el sector pesquero fue uno de los más afectados debido al amarre de la flota.

El resto de notas, es decir 55, se dedica a dar cuenta de la erupción y de los fenómenos naturales que lleva aparejados, así como de las repercusiones sobre la población de la isla como son las evacuaciones que sufrieron los habitantes de La Restinga. En este sentido destaca que, en 6 de las notas, un 10 por ciento, se hace referencia a las posibles consecuencias que podría tener la erupción volcánica sobre la salud de la población debido a la emisión de gases e, incluso, se recomienda no consumir pescado de la zona en la que se produjo dicha erupción.

Las primeras informaciones sobre este tema se publicaron el día 11 de octubre de 2011, como se ha indicado anteriormente. Destaca la insertada el día 20, con el titular "Desconcierto volcánico" que es un reportaje amplio en el que se recogen las opiniones de vecinos, así como de científicos y representantes de la Administración regional. Además, en todo el período analizado tan sólo hay dos entrevistas indirectas; una a la responsable de vulcanología del Instituto Geográfico Nacional, Carmen López, publicada el día 15 de julio de 2012; y otra al Director General de Seguridad y Emergencias del Gobierno de Canarias, Juan Manuel Santana, publicada el 8 de noviembre de 2011. 
En cuanto a las fuentes citadas en las informaciones; por un lado, estaría el bloque científico en el que se incluyen los organismos que intervienen en el proceso: el Instituto Geográfico Nacional, a través de la responsable de vulcanología, Carmen López, de su directora en Canarias, María José Blanco, de su página web, de la Red de Vigilancia Volcánica, y de científicos como Rafael Abella; el Instituto Español de Oceanografía y su jefe de flota, José Ignacio Díaz; el Consejo Superior de Investigaciones Científicas, a través de los científicos, Ramón Ortiz y Joan Martí, de expertos y de su vicepresidente de Relaciones Institucionales; el jefe de campaña del buque Ramón Margalef, Juan Acosta; el vulcanólogo, Juan Carlos Carracedo, una autoridad en la materia que lleva 45 años estudiando los volcanes; Alberto Brito, catedrático de Zoología y Oceanografía Biológica de la ULL; el Involcan, a través de su coordinador, Nemesio Pérez; el Instituto Geológico y Minero, a través de Miguel Llorente; Domingo Gimeno de la Facultad de Geología de la Universidad de Barcelona; el Instituto de Ciencias Marinas; y expertos, científicos, biólogos, sismólogos, y vulcanólogos, en general.

Por otro estarían las autoridades públicas, tanto locales como regionales y nacionales, que serían las que se relaciona a continuación: el Gobierno de Canarias con carácter genérico, el presidente del ejecutivo regional, la Dirección General de Seguridad y Emergencias, a través de su director, y de su portavoz; el Pevolca; la Consejería de Economía, Hacienda y Seguridad; la Consejería de Sanidad, a través de la Dirección General de Salud Pública; el subdelegado del Gobierno en la provincia de Santa Cruz de Tenerife; el ministro de Industria y Energía del Gobierno español, José Manuel Soria; el Ministerio de Ciencia e Innovación; la Unidad Militar de Emergencias; la Secretaría General del Mar; Capitanía Marítima; Protección Civil; el Cabildo de El Hierro, a través de su presidente, Alpidio Armas, y de la Consejera de Seguridad y Emergencias; el alcalde de El Pinar y el concejal de Seguridad de la localidad; y el alcalde de Frontera.

En los cuadros siguientes se especifica, agrupado por estamentos, el número de veces en las que aparecen citadas las fuentes mencionadas 
en los párrafos anteriores y el porcentaje de informaciones correspondiente.

\begin{tabular}{|l|l|l|}
\hline Fuentes Científicas & $\begin{array}{l}\mathbf{N}^{\mathbf{o}} \text { Informaciones en } \\
\text { las que se les cita }\end{array}$ & Porcentaje \\
\hline Instituto Geográfico Nacional & 30 & 50.8 \\
\hline Instituto Español de Oceanografía & 8 & 13.5 \\
\hline $\begin{array}{l}\text { Consejo Superior de Investigaciones } \\
\text { Científicas }\end{array}$ & 7 & 11.8 \\
\hline $\begin{array}{l}\text { Juan Carlos Carracedo/Alberto } \\
\text { Brito }\end{array}$ & 8 & 13.5 \\
\hline Involcan/Nemesio Pérez & 3 & 5 \\
\hline $\begin{array}{l}\text { Expertos en general/otras } \\
\text { instituciones científicas }\end{array}$ & 14 & 23.7 \\
\hline
\end{tabular}

\begin{tabular}{|l|l|l|}
\hline Fuentes Institucionales & $\begin{array}{l}\mathbf{N}^{\mathbf{o}} \text { informaciones en las } \\
\text { que se les cita }\end{array}$ & Porcentaje \\
\hline $\begin{array}{l}\text { Gobierno de Canarias(distintos } \\
\text { departamentos) }\end{array}$ & 20 & 33.8 \\
\hline $\begin{array}{l}\text { Dirección General de Seguridad y } \\
\text { Emergencias/Pevolca }\end{array}$ & 12 & 20.3 \\
\hline $\begin{array}{l}\text { Gobierno Central(varios } \\
\text { departamentos) }\end{array}$ & 3 & 5 \\
\hline Cabildo de El Hierro & 12 & 20.3 \\
\hline Alcaldes El Hierro & 6 & 10.1 \\
\hline
\end{tabular}

Otras fuentes que aparecen citadas en los textos son: un guardia forestal, vecinos, comerciantes y empresarios de la isla, como propietarios de restaurantes, de un club de buceo, de apartamentos, tiendas, etc; los presidentes de Asevalle y Apyme, Jorge Benítez y Herminio Sánchez, respectivamente; el presidente de la Cofradía de Pescadores de La Restinga, Fernando Gutiérrez, quien interviene con bastante frecuencia, hasta en 7 informaciones, lo que supone un 11 
por ciento del total, pescadores, turistas y trabajadores de varios sectores que narran las consecuencias de la erupción para sus negocios y para su vida cotidiana.

Fuentes muy puntuales son la directora administrativa de Telefónica en Canarias y Actualidad Volcánica de Canarias (Avcan).

Igualmente, se recurre como fuente a agencias de noticias, como Efe, Europa Press y Acfi press, y a otros medios de comunicación, como la Cadena Cope y prensa local.

\subsection{Análisis: E1 Mundo}

El periódico El Mundo publicó un total de 43 informaciones durante el período de estudio que comprende este trabajo. El día de la erupción este diario publicó, como se ha indicado, dos informaciones tituladas "El Hierro registra una erupción submarina a 5 kilómetros de la costa" y "La erupción en El Hierro, un espectáculo submarino imposible de observar". Llama la atención que, en todo el período analizado, no hay ni una sola entrevista.

Por lo que respecta a los temas tratados, cabe destacar que la mayoría de las informaciones se centra en narrar el desarrollo del proceso eruptivo, mientras que tan sólo 2 , un 4.6 por ciento, se dedican exclusivamente a temas de carácter económico relacionados con la crisis desencadenada en la isla. Son las publicadas el día 10/11/2011 con los siguientes titulares: "Empresarios de El Hierro piden medidas urgentes por la crisis del volcán" y "Aprobadas ayudas urgentes para El Hierro, que se cobrarán en diez días", aunque en un total de 11 informaciones, un 25.5 por ciento, se hace algún tipo de referencia a las consecuencias económicas de la crisis volcánica. Asimismo, también se hace mención a los posibles efectos nocivos para la salud en 3 notas, lo que supone un 6.9 por ciento.

En cuanto a las fuentes citadas, las correspondientes al ámbito científico son: el Instituto Geográfico Nacional, a través de María José Blanco, Carmen López y Emilio Carreño, y de la página web de dicho organismo; el Consejo Superior de Investigaciones Científicas, a través del coordinador del equipo de científicos, Ramón Ortiz, de la 
experta Alicia García y de Joan Martí; el Instituto Geológico y Minero de España, a través de su portavoz, Miguel Regueiro; científicos de la Universidad de Cádiz; el científico de la Plataforma Continental de Canarias Carlos Barrera; el Involcan, el Director del Instituto de Investigación en Diseño y Fabricación de la Universidad Politécnica de Valencia, Josep Tornero; el grupo de investigación Bioecomac de la Universidad de La Laguna; el Instituto Español de Oceanografía, a través de su jefe de flota, José Ignacio Díaz, del experto Eugenio Fraile y de Jesús Rivera, oceanógrafo, así como de Francisco Sánchez, jefe de campaña del Buque Ramón Margalef; expertos, técnicos e instituciones científicas canarias, en general.

\begin{tabular}{|l|l|l|}
\hline Fuentes Científicas & $\begin{array}{l}\mathbf{N}^{\mathbf{0}} \text { Informaciones en } \\
\text { las que se les cita }\end{array}$ & Porcentaje \\
\hline Instituto Geográfico Nacional & 22 & 51.1 \\
\hline $\begin{array}{l}\text { Instituto Español de } \\
\text { Oceanografía }\end{array}$ & 4 & 9.3 \\
\hline $\begin{array}{l}\text { Consejo Superior de } \\
\text { Investigaciones Científicas }\end{array}$ & 8 & 18.6 \\
\hline Involcan & 4 & 9.3 \\
\hline $\begin{array}{l}\text { Expertos/instituciones } \\
\text { científicas en general }\end{array}$ & 12 & 27.9 \\
\hline
\end{tabular}

En este ámbito cabe destacar que el reportaje titulado "Los vigilantes del volcán", publicado el 13/11/2011, se refiere al Foro Todogeología Tenerife, que congrega a los voluntarios y seguidores de 'Volcanes de Canarias', un portal informativo que da a conocer la evolución del fenómeno eruptivo. Dicho portal cuenta con la colaboración y asesoramiento de expertos de reconocido prestigio. Asimismo, la organización ecologista Oceana es la protagonista de la información publicada el 5 de noviembre de 2011, en la que se explica que esta entidad propone la creación de un área marina protegida alrededor de la isla de El Hierro. 
En cuanto a las fuentes institucionales, la relación sería la siguiente: el Cabildo de El Hierro, a través de la consejera de Seguridad y Emergencias y de su presidente; el director general de Seguridad y Emergencias del Gobierno de Canarias, que es también portavoz del Pevolca; el ejecutivo regional en sentido amplio, y concretamente a través de su presidente y vicepresidente; el alcalde de El Pinar; el Ayuntamiento de Frontera; la Dirección General de Protección Civil y Emergencias del Ministerio del Interior; el Servicio de Urgencias 112; la Consejería de Economía, Hacienda y Seguridad del Gobierno regional; la Consejería de Sanidad, a través de la Dirección General de Salud Pública; el CECOES y el Ministerio del Interior.

\begin{tabular}{|l|l|l|}
\hline Fuentes Institucionales & $\begin{array}{l}\mathbf{N}^{\mathbf{o}} \text { informaciones en las que } \\
\text { se les cita }\end{array}$ & Porcentaje \\
\hline $\begin{array}{l}\text { Gobierno de Canarias(varios } \\
\text { departamentos) }\end{array}$ & 11 & 25.5 \\
\hline $\begin{array}{l}\text { Director General de Seguridad y } \\
\text { Emergencias }\end{array}$ & 16 & 39.5 \\
\hline Cabildo de El Hierro & 9 & 20.9 \\
\hline $\begin{array}{l}\text { Gobierno central (Ministerio del } \\
\text { Interior) }\end{array}$ & 2 & 4.6 \\
\hline Ayuntamientos de El Hierro & 2 & 4.6 \\
\hline
\end{tabular}

Otras fuentes a las que se cita son: los vecinos, empresarios, y concretamente la Asociación de Pequeña y Mediana Empresa, pescadores y profesores de la isla de El Hierro.

Igualmente se recurre como fuente a agencias de noticias, como Efe, Europa Press y Servimedia, y a otros medios de comunicación, como la Cadena Ser, Canarias Radio la Autonómica y la Televisión Canaria.

\subsection{Análisis: Titulares}

\subsubsection{Titulares que generan alarma}

Ante una situación de crisis como la vivida, uno de los aspectos que es motivo de estudio en el presente trabajo es si en los titulares de las 
informaciones publicadas se utilizó términos que puedan generar alarma o bien tranquilizar a una población que se enfrenta por primera vez a una situación como esta y que necesita estar bien informada para saber qué ocurre realmente. En estos casos los medios de comunicación tienen que hacer gala de su responsabilidad social que, según Solano Santos (2012: 2-5),

"se extiende a los conflictos y catástrofes, que exigen a los medios un tratamiento informativo objetivo, riguroso y veraz, acorde a una responsabilidad social específica.(...) La catástrofe o desastre es un hecho natural o provocado por el ser humano que afecta de forma negativa a la vida, al sustento o a la industria, cuyas consecuencias originan frecuentemente cambios permanentes en las sociedades humanas, en el ecosistema y en el medio ambiente poniendo de manifiesto la vulnerabilidad del equilibrio necesario y fundamental para no sólo progresar, sino y lo que es más importante, sobrevivir."

Para catalogar los titulares y definir si generan alarma se ha establecido una serie de marcadores en forma de palabras clave, como son alerta/prealerta, crisis, prohibición, evacuación, explosión, emergencia, radioactividad, peligro, temor, riesgo ${ }^{6}$, alarma, $^{2}$ incertidumbre, semáforo rojo y mayor.

De esta forma, encontramos que, en el periódico El Mundo, los titulares que pueden generar alarma son los siguientes: "Activan la prealerta amarilla en El Hierro tras detectarse movimiento de magma"(27/06/12); "El Hierro registra el mayor terremoto desde el origen del proceso volcánico"(11/11/11); "El agua junto al volcán de El Hierro es 1.000 veces más ácida"(10/11/11); "Prohíben el acceso a dos calas en El Hierro por riesgo de gases"(9/11/11); “Ordenan evacuar de nuevo a la población de La Restinga por la erupción volcánica"(6/11/11); “Interior 'prealerta' al Comité de Riesgo Volcánico por la situación en El Hierro"(3/11/11) y "La erupción de

\footnotetext{
${ }^{6} \mathrm{El}$ riesgo se diferencia de la crisis en tanto que representa un peligro potencial: la probabilidad de que algo adverso pueda ocurrir y las consecuencias que se puedan derivar de dicha adversidad. La crisis, en cambio, es una situación que antes de que acontezca es imprevisible y que conlleva efectos negativos para alguna organización o persona.
} 
El Hierro afecta ya a casi 100 especies marinas"(4/11/11). Serían un total de 7 sobre 43 , lo que supone un 16.2 por ciento.

En el diario El País las informaciones que presentan titulares que generan alarma son: "Fragmentos de lava de gran tamaño salen a la superficie en El Hierro"(30/01/12); "Las autoridades evacuan por segunda vez La Restinga por la erupción volcánica”(5/11/11); “El Hierro registra un terremoto de magnitud 4.3, el mayor desde la erupción de octubre"(2/11/11); "La erupción de El Hierro se acerca a la superficie y se hace más peligrosa"(15/10/11); "Dos seísmos de 3.9 en El Hierro disparan el temor a una nueva erupción"(30/10/11); "El Hierro teme otra erupción, y peor"(11/10/11); "El Hierro registra el terremoto más fuerte desde que comenzó la crisis"(11/11/11); "Interior pone en "prealerta" al comité de crisis en El Hierro"(3/11/11); "Canarias autoriza el realojo de La Restinga 24 horas después de elevar la alerta"(16/10/11); "El magma de El Hierro es más explosivo de lo previsto" $(2 / 11 / 11)$ y "El riesgo por gases obliga a cerrar dos calas del sur de El Hierro"(9/11/11). Serían 11 de un total de 59 , lo que supone un 18.6 por ciento.

En el caso de Canarias 7, el titular que despierta inquietud es el siguiente: "Las piedras de la erupción de El Hierro, de las más radiactivas El Mundo" (4/08/12). Dado que este diario solo publicó 5 notas sería un 20 por ciento del total.

Finalmente, el periódico El Día, que es el que más notas publica en este período presenta los titulares siguientes: "Elevan a semáforo rojo el riesgo volcánico en la zona de La Restinga"(11/10/11); “Alerta roja y evacuación en La Restinga ante una posible erupción volcánica”(12/10/11); "El Comité de Riesgo Volcánico mantiene el nivel 1 de emergencia en El Hierro" (17/10/2011); "La erupción volcánica eleva hasta 6 veces los valores normales de CO2 en E1 Hierro"(25/11/11); "El volcán vuelve a provocar otro estallido superficial de vapor y ceniza"(08/11/11); “Geólogos de la UB alertan de que el magma es de los más explosivos"(03/11/11); "Interior pone en "prealerta" a los miembros del Comité Estatal de Riesgo Volcánico"(03/11/11); "El Ayuntamiento de El Pinar declara la situación de emergencia económica y social"(16/10/11); "El Comité de Riesgo volcánico mantiene el nivel 1 de emergencia en El Hierro"(17/10/11); “Alerta roja y evacuación en La Restinga ante 
una posible erupción volcánica"(12/10/11); "Elevan a semáforo rojo el riesgo volcánico en la zona de La Restinga(El Hierro)"(11/10/11); "El Pevolca limita el semáforo rojo por riesgo volcánico a la zona de exclusión marítima en El Hierro" (07/12/11); "Siguen los sismos en El Hierro casi un año después de la crisis"(20/06/12); "Alerta volcánica tras detectarse magma en movimiento en La Dehesa y El Julan" (28/06/12); "Cuatro meses de erupción submarina en un mar de incertidumbres"(10/02/12); "Las piedras de la erupción de El Hierro, de las más radiactivas El Mundo"(4/08/12); "El aumento de la sismicidad alarma al Instituto Geográfico" (17/09/2012) y "La crisis sísmica en $\mathrm{El}$ Hierro se reactiva con más intensidad y celeridad"(18/09/12). Se trataría de 18 casos lo que representa un 6.7 por ciento del total.

\subsubsection{Titulares que tranquilizan}

Al igual que ocurría en el epígrafe anterior, las palabras clave para establecer si los titulares contribuyen a crear un ambiente de calma entre la población son las siguientes: estabilidad, tranquilidad, normalidad, alivio, ánimo, fin erupción y semáforo verde.

En el caso del diario El Mundo el único titular es "Anulan las medidas de protección en El Hierro al estabilizarse la actividad sísmica" $(26 / 11 / 11)$, lo que representa un 2.3 por ciento del total.

En el periódico El País, los casos son los siguientes: "El fenómeno eruptivo de El Hierro está en "proceso de normalización" (28/02/12); "Los Príncipes visitan el Hierro para animar a los turistas a volver" (30/01/12); "Los científicos dan por terminada la erupción volcánica de El Hierro" (5/03/12). Estos resultados suponen el 5 por ciento del total.

En el caso de El Día, encontramos: "Los valores de emisión $\mathrm{CO}_{2}$ del volcán de El Hierro no representan ningún riesgo para la población" (11/07/2012); "El Hierro recupera semáforo verde en tierra y amarillo en la zona del volcán"(19/04/12); "El Cabildo espera que la visita de los Príncipes de "normalidad" a la Isla"(29/01/12); "Nuevos piroclastos en el mar, aunque el tremor se mantiene estable"(15/01/12); "Se mantiene la situación de estabilidad 
sísmica"(27/11/11); "Los expertos piden que no se baje la guardia en El Hierro, pero aseguran que la población puede estar tranquila" (13/10/11); y "Se estabiliza la emergencia volcánica en El Hierro, dice Interior" (13/10/11). Se trata de un 2.6 por ciento del total de notas publicadas por este diario.

\section{Conclusiones}

-Los periódicos El Día, El Mundo y El País siguen el paso marcado por el Gobierno de Canarias y la estrategia de comunicación diseñada desde la Dirección General de Seguridad y Emergencias del Gobierno de Canarias que lidera la difusión de las informaciones sobre el fenómeno eruptivo.

-Las fuentes institucionales alternativas están focalizadas en el Cabildo de El Hierro y los ayuntamientos, mientras que la presencia de otros organismos es testimonial.

-Las fuentes científicas son básicamente organismos oficiales de rango estatal que tienen expertos trabajando en la isla y cabe destacar la presencia circunstancial de autoridades locales en la materia como Juan Carlos Carracedo.

-La importancia de las consecuencias económicas del fenómeno se plasma en la presencia en los textos de una notable variedad de fuentes vinculadas al sector.

-Los diarios El Día, El País y El Mundo ofrecen una cobertura destacada, que se eleva por encima del 20 por ciento, a las consecuencias económicas de la crisis volcánica.

-Los periódicos que presentan una mayor tendencia al alarmismo en sus titulares son El País y El Mundo donde los porcentajes superan el 15 por ciento en ambos casos, destacando que, en el primero de los diarios, casi se llega al 20 por ciento. 


\section{Bibliografía}

Lorente, José Ignacio (2014): “La gestión informativa del riesgo medioambiental", en Cuadernos de Información y comunicación, Vol. 19, pp. 179-194.

Lundgren, Regina E. y McMakin, Andrea H: Comunicación de riesgos. Una guía para la comunicación de riesgos ambientales, de seguridad y de salud. Cuarta edición: http://cursos.campusvirtualsp.org/pluginfile.php/20953/mod page/content/ $1 /$ documentos modulos/lundgren-momakin-introduccion-a-la-comunicacionde-riesgo.pdf consultada el 15 de agosto de 2014.

Mariño, Miguel Vicente: "Comunicación medioambiental: consolidando un campo de investigación", Centro de Investigación para la Paz(Cip-Ecosocial): https://www.fuhem.es/media/ecosocial/File/Proyecto $\% 20$ Cultura $\% 20 \mathrm{y} \% 20 \mathrm{~A}$ mbiente/Art $\%$ C3\%ADculos/Comunicacion $\% 20$ medioambiental_MARI $\% \mathrm{C} 3$ \%910.pdf consultada el 15 de septiembre de 2014.

Solano Santos, Luis Felipe (2012) "La responsabilidad social de los medios de comunicación ante el conflicto y la catástrofe", en Estudios sobre el mensaje periodístico, Vol. 18, n²2, pp. 613-622.

Túñez López, Miguel y Sixto García, José (2012): Las redes sociales en las estrategias de comunicación: del Prestige a Fukushima:

http://www.aeic2012tarragona.org/comunicacions_cd/ok/147.pdf, consultada el 20 de junio de 2014. 


\title{
Plataformas antifracking y construcción mediática del riesgo
}

\author{
Àngels Álvarez Villa - Universidad CEU Cardenal Herrera - \\ aalvarez@uch.ceu.es
}

Ángel Castaños Martínez - Universidad CEU Cardenal Herrera ajc@uch.ceu.es

Ma Teresa Mercado Sáez - Universidad CEU Cardenal Herrera mmercado@uch.ceu.es

Resumen: La fracturación hidráulica, conocida por el término en inglés fracking, es una técnica de extracción de gas y petróleo no convencional utilizadas desde hace más de quince años en Estados Unidos. El uso de este procedimiento, que fractura roca a gran profundidad mediante la inyección de agua a presión, es controvertido. Algunos países lo han prohibido o han impuesto moratorias; otros lo fomentan u optan por la regulación. A principios de 2014, la Unión Europea dio luz verde a que cada país miembro pudiera "explorar o explotar" yacimientos de gas no convencional, según su criterio. En España, hay cientos de permisos solicitados o concedidos de una veintena de empresas interesadas y decenas de plataformas o asociaciones ciudadanas contrarias a esta técnica.

Esta investigación analiza por un lado, la presencia del fracking en los diarios españoles El País, El Mundo, Abc, El Periódico, La Razón, La Vanguardia y Público durante 2012 (año en que aparece el debate en los 
medios) en términos de beneficio (a favor) o riesgo (en contra), a partir del análisis de las posiciones de las fuentes que aparecen en las noticias. Mediante el análisis de contenido, se establece el impacto de las plataformas antifracking en la agenda mediática centrándonos en su aparición en los medios como fuente informativa. Se estudia la estrategia informativa y páginas web de las principales plataformas (información sobre su composición, contenidos que ofrece, posibilidad de participación, acciones que promueve).

Para el análisis de las 'websites' de las plataformas ciudadanas, la metodología empleada se basa en la cuantificación de las cuatro variables definidas por Dader y Ayuso (2008).

Los resultados demuestran que las plataformas ciudadanas constituidas para luchar con el fracking han conseguido visibilidad y atención mediática, apareciendo en cerca de un tercio de las informaciones que informaban sobre el tema en 2012. Sin embargo, son los políticos las fuentes más frecuente lo que muestra que continúan siendo, también es este asunto, los actores principales en el discurso informativo.

La investigación forma parte del proyecto del Plan Nacional I+D+i referencia CSO2012-38363.

Palabras clave: fracking, medios, política energética, participación ciudadana.

\section{Introducción}

PORTUNIDAD de oro o riesgo innecesario. El entusiasmo por la extracción de gas 'no convencional' reaviva nuevamente un debate que no deja indiferente a nadie con relación a qué modelo energético queremos. En el horizonte surgen voces que se muestran a favor y otras en contra de la polémica técnica de la fractura hidráulica. Los distintos actores, sociedad, ecologistas, políticos y expertos muestran su punto de vista, lo que provoca que los planes de la industria tropiecen con ejemplos de contestación social. La técnica de prospección para la extracción de gas natural de modo no convencional, conocida como fracturación hidráulica (fracking), se ha 
usado de forma pionera en Estados Unidos en los últimos quince años. Su llegada a Europa, sin embargo, ha supuesto el establecimiento de moratorias en algunos de sus estados ante la falta de garantías ambientales. Existen dudas en la comunidad científica sobre la compatibilidad de esta actividad con la preservación del medio ambiente y la salud. Entre las razones que aducen quienes se oponen frontalmente, se señala que puede contaminar los acuíferos, al tener efectos adversos sobre las aguas subterráneas y entrañar peligros para el medioambiente y la salud.

La técnica no está regulada por la UE, por lo que las autorizaciones y prohibiciones se realizan a criterio de cada estado, y países como Francia, Bulgaria o Irlanda del Norte han prohibido o suspendido esta actividad. En otros continentes, países como Australia, Canadá o Sudáfrica han aprobado también la suspensión temporal hasta comprobar las consecuencias que genera.

En España, el Gobierno de José Luis Rodríguez Zapatero aprobó extracciones con esta técnica en las comunidades de Cantabria, País Vasco, Castilla y León, La Rioja, Aragón y Andalucía. Centrándonos en el caso cántabro, en enero de 2011 el Ministerio de Industria concedió a Repsol el permiso de investigación "Luena" para evaluar la posibilidad de extraer gas natural a través de esa técnica en varios valles de Cantabria y en comarcas del norte de Burgos. Sin embargo, el gobierno cántabro acabó aprobando la prohibición del uso de esta técnica convirtiéndose en la primera comunidad autónoma en aprobar una ley antifracking, a la que siguieron Asturias y Galicia. A esta oposición se añaden provincias como Valladolid, que el 26 de octubre de 2012 se declaró "Provincia Libre de Fracturación Hidráulica (Fracking)", y Soria, que en julio de 2012 aprobó una moción contra la fractura hidráulica. Igualmente varias localidadaes se han declarado 'municipios libres de fracking' (MLF). Por ejemplo, el Ayuntamiento de Valencia se opone a la práctica de la fracturación hidráulica para la investigación y extracción de hidrocarburos, por tratarse de una técnica considerada "agresiva" con el medio ambiente, según acordó en abril de 2013 por unanimidad la Comisión municipal de Medio ambiente.

Frente a estos argumentos se muestran a favor de la técnica quienes ven una oportunidad única para la inversión y la creación de empleo. 
Se reclama la necesidad de un estudio transparente, independiente y detallado sobre el impacto. Las empresas afectadas son empresas líderes en el sector, como Ripsa (Repsol), Shesa, BNK España, Montero Energy y Petrichor y solicitan un debate objetivo sobre esta técnica.

Desde 2011, han ido apareciendo plataformas ciudadanas dispuestas a luchar contra la extracción de gas mediante el procedimiento de la fractura hidráulica. Las más significativas transmiten sus mensajes para apoyar y difundir su postura a través de sitios webs alojados en la red de Internet.

El objetivo de esta investigación es precisamente analizar a estas plataformas como nuevos actores informativos a tener en cuenta en los temas energéticos junto a organizaciones no gubernamentales (ONG) de carácter ambientalista, políticos, científicos y empresas.

\section{Metodología}

La investigación se centra en dos ámbitos distintos. Por un lado, se estudian los sitios web de las plataformas antifracking en activo en 2012 y que permanecen en activo en mayo de 2013. Por otro, mediante la técnica del análisis de contenido, observamos la atención mediática al asunto del fracking y la presencia de estas asociaciones o colectivos. El objetivo es determinar su aparición y describir cómo aparecen mencionadas.

\subsection{Análisis de las plataformas anti fracking en la red}

Para determinar quiénes son los principales actores que encuentran espacio en nuestro análisis se recurre a la utilización del motor de búsqueda de Google, por ser este el más utilizado. Se ha limitado el campo de estudio a España por el interés del valor de la cercanía. Se introdujeron términos, tanto en inglés como en castellano, y en diversas combinaciones para realizar la búsqueda los siguientes vocablos: fracking, plataforma, antifraking, no, fractura hidráulica. Fruto de esta búsqueda se obtiene unos resultados en los que se pueden incluir sitios web en sentido estricto, bitácoras o blogs y 
otros. Si bien se pueden establecer diferencias entre ambos y nuestra intención inicial nos orientaba a los sitios web, hemos considerado incluir los blogs en nuestro análisis por tres razones: pueden ser configurados para funcionar como un sitio web, la posibilidad de la gratuidad en el alojamiento y el uso de las herramientas de edición hacen de los blogs el recurso de aquellos que carecen de los conocimientos técnicos y los recursos económicos para administrar un sitio web en sentido estricto, tal y como apuntan Baviera y Civera (López García, 2013), y parecen - en principio- una herramienta ideal para interactuar por su arquitectura entrada-comentario, trazo insoslayable en cualquier iniciativa que quiera mostrarse como plataforma participativa.

Para la revisión de los sitios web de las plataformas ciudadanas, la metodología empleada se basa parcialmente en la cuantificación definida por Dader y Ayuso para el análisis de las webs de los partidos políticos (Dader y Ayuso, 2008; Dader, 2009), concretamente en lo referido por los autores como categoría "Suministro de Información". Las tres restantes categorías que los autores presentan en su modelo -basado en trabajos previos (De Landtsheer, Krasnoboka y Neuner, 2001) - interactividad, sencillez de uso y estética, las hemos aparcado para futuras investigaciones, recurriendo a los criterios de los estudios realizados desde el campo de la usabilidad web, por evaluar dimensiones sensibles a los cambios tecnológicos y que quedan recogidas de forma más actualizada con dichas herramientas de análisis. Completaremos, sin embargo, el estudio intentado verificar con listas de comprobación los posibles errores de usabilidad de los sitios web de las plataformas cometidos en su relación con los medios de prensa (Nielsen, 2009).

Con el objetivo de determinar la dimensión 'información' y sus valores categoriales según el modelo Dader (el volumen, la calidad y la utilidad de la información proporcionada) se analizan cinco subdimensiones: auto- presentación y relaciones públicas, información externa, información de generalidades, documentación elaborada en profundidad, información de contexto. A diferencia del modelo original de De Landtsheer (2001) por la dimensión y objetivos de este trabajo y reservándonos para un estudio ulterior de mayor detalle, codificaremos los resultados de las dimensiones 
mediante la observación de los sitios y herramientas web sin aplicar valores de ponderación.

Respecto al análisis del contacto con lo medios, el cuadro de alerta de Nielsen (2009) advierte sobre el uso de ciertas malas prácticas cuyo uso se debería evitar, como limitar el uso de la nota de prensa en formato PDF, a favor de formatos multimedia. Contabilizaremos los ítems informativos de elaboración propia y no aquellos que siendo de factura ajena a las plataformas son redistribuidos por estas.

\subsection{Análisis de la presencia de las plataformas anti fracking en los medios}

Para analizar la atención mediática al asunto del fracking y la presencia de las plataformas anti fracking se establece 2012 como periodo de análisis y una muestra compuesta por 8 diarios online: elpais.com, elmundo.es, abc.com, elperiodic.com. larazon.es, lavanguardia.com, publico.es y eldiario.es. Las unidades de análisis son todos aquellos textos en los que se haga referencia a la palabra clave 'fracking'. Para su identificación se procederá a una doble búsqueda: en las hemerotecas digitales y en el servicio de clipping MyNews.

Aplicando la técnica del análisis de contenido para la recogida de datos (Kripendorff, 1990, Igartua y Humanes, 2004, Igartua, 2006) se prepara un programa de codificación con las siguientes variables descriptivas en cada unidad de análisis: fecha de publicación, cabecera, sección, titular, autoría (firma), género, inclusión o no de elementos gráficos $\mathrm{y} / \mathrm{o}$ fotografía, fuentes mencionadas, denominación de plataforma anti fracking y posición de las fuentes.

Esta última variable recoge la postura manifiesta de las fuentes pro o antifracking. No implica una lectura cualitativa puesto que en el texto aparecen las declaraciones con la posición explícita al respecto. Las categorías son: textos en los que se nombra únicamente a voces contrarias al "fracking", textos en los que sólo aparecen fuentes a favor del "fracking" y aquellos textos en los que se muestran ambos puntos de vista. 


\section{Resultados}

La búsqueda exhaustiva de plataformas en activo ha dado como resultado la identificación de 16 plataformas, asociaciones o colectivos que mantienen una identidad diferenciada en la web a través de distintos recursos (sitio web, blog o bitácora, perfil en Facebook o cuenta en twitter.

Los sitios web, bitácoras y cuentas de Twitter y Facebook contenidos en la tabla anterior localizan sus zonas de actuación en las comunidades autónomas afectadas por el fenómeno del fracking. A saber: Andalucía, Cataluña, Comunidad Valenciana, Castilla y León, País Vasco, Castilla-La Mancha, Aragón, Principado de Asturias, Navarra, Cantabria y La Rioja.

En nuestro estudio hemos seleccionado alguno de los resultados antes listados, priorizando de cada plataforma las herramientas por el siguiente orden: página web, bitácora, perfil de Facebook. En los casos de la existencia de más de una herramienta, se ha estudiado la primera.

La información oficial sobre los sondeos, permisos de investigación y concesiones de explotación puede encontrase en el sitio web del Ministerio de Industria, Turismo y Comercio (2013). Los mapas allí expuestos presentan las diversas zonas de actuación. Hay que hacer notar, sin embargo, que si bien la información aparece desde el año 2004, los mapas e informaciones textuales allí expuestas presentan un listado de las zonas de actuación con nombres adhoc del posible yacimiento, sin tener referencia al nombre de la población afectada. Tampoco se discrimina el tipo de hidrocarburo de la prospección y se engloba todos ellos bajo el epígrafe EL PETRÓLEO, facilitando poco al lector el acceso claro a la información; muy al contrario de lo hecho por las plataformas antifracking, que en sus nombres incluyen los de las poblaciones, regiones o comunidad autónoma a la que su acción se circunscribe.

En el sitio web de la Asamblea contra la Fractura Hidráulica de Cantabria (2013) puede encontrarse un mapa interactivo, creado 
mediante la herramienta de MapQuest que, a diferencia de el del ministerio, sí presenta solo las zonas afectadas por el fracking

Casi la totalidad de la plataformas, salvo la excepción de Fracking ez Bizkaia, cumplen con más de la mitad de los requisitos de suministro de información. Un cuarto del total (Plataforma Andalucía libre de Fracking, Plataforma Asturiana Anti-Fracking, Plataforma Aturem el Fracking (PAF) y Plataforma fracking NO de La Rioja) se ajusta a todas las subdimensiones de las que se espera posean.

Las dos subdimensiones que cubren la totalidad de las plataformas son aquellas referidas a su capacidad para instar a la acción y la posibilidad de la participación ciudadana. La subdimensión que menos se cubre es la referida a la identificación de las plataformas.

Respecto a las dimensiones relacionadas con los medios de comunicación, si bien casi la totalidad de ellas están preocupadas por reflejar qué dicen los medios, no son tantos los esfuerzos por dar acceso a los periodistas a un nombre o un teléfono de un, se supone inexistente, responsable de prensa.

En cuanto a la presencia del asunto en los medios, se han encontrado 254 piezas en los diarios analizados. La atención se incrementa en el último trimestre del año tras la decisión del Gobierno de Cantabria de prohibir la extracción de gas natural que activa la presencia de las empresas afectadas, líderes en el sector.

Ripsa (Repsol), Shesa, BNK España, Montero Energy y Petrichor, todas ellas con permisos de investigación solicitados o concedidos por el Gobierno central o por el autonómico, lamentan que se anule lo que definen como una "oportunidad única" para la inversión y la creación de empleo en la zona.

La Asociación Española de Compañías de Investigación, Exploración y Producción de Hidrocarburos y Almacenamiento Subterráneo (ACIEP), que agrupa entre otras, a las empresas afectadas, asegura que la tecnología permite que la fracturación hidráulica se lleve a cabo únicamente utilizando técnicas y productos "respetuosos con el medio ambiente y la protección de las aguas subterráneas" (Europa Press, 6 noviembre 2011). A partir de este momento, aumenta de manera significativa el número de informaciones referidas al asunto. 
Por diarios, es La Vanguardia donde aparecen más informaciones aunque no son las plataformas catalanas las más mencionadas.

Respecto a la aparición de las plataformas, en el 31,5 por ciento de las piezas sobre fracking $(n=80)$, aparecen mencionadas como fuentes las plataformas anti fracking de distintas maneras.

Claramente, las dos plataformas que han conseguido mayor impacto mediático son Fracking Ez Araba (No al Fracking en Álava) y la Asamblea contra la Fractura Hidráulica de Cantabria, denominada oficialmente en su website Fractura Hidráulica No de Cantabria. Ambas aparecen como fuente antifracking principal en 30 y 28 ocasiones, respectivamente. En 8 ocasiones comparten protagonismo con otras plataformas de la zona norte de España: Fracking Ez Ez Biscaia, Plataforma Fracking No de La Rioja, Asamblea contra la Fractura Hidráulica de Burgos, la Asamblea de Palencia (Campoo-Los Valles), Fracking Ez Navarroa, Fracking Ez Kuartango y el Colectivo Sandía (La Rioja).

Tanto Ez Araba como la Asamblea de Campoo-Los Valles está incardinadas en Ez Araba y Asamblea de Cantabria.

La otra zona en la que los colectivos antifracking han tenido impacto en los medios de difusión nacional es en Cataluña y Castellón, aunque en mucha menor medida que las anteriores. Así, la plataforma Anti fracking de les Comarques de Castelló es mencionada en 5 ocasiones y nunca con su nombre completo. En este caso, se utiliza la expresión 'plataforma antifracking' entendiéndose por el contexto de la información a cuál se refieren.

La catalana Aturem el Fracking sólo aparece en 2 ocasiones. La Plataforma Fracking No de La Rioja aparece también en solitario en 2 menciones. En los darios analizados, no aparecen las plataformas analizadas en Castilla La Mancha, Andalucía o Aragón.

Como se ha explicado anteriormente, algunas de las plataformas o colectivos que aparecen como fuentes en los diarios no han creado ningún recurso online, como por ejemplo el Grupo Río Miera (Santander). 
En 20 de estas 81 piezas junto a la denominación 'oficial' de la plataforma aparecen expresiones como agrupación, asamblea, asociaciones ciudadanas colectivo, colectivos ecologistas, grupos sociales críticos con el proyecto, movimiento ecologista, opositores, opositores a esta técnica, organización, plataforma ecologista

En algunas ocasiones, no aparece identificada la plataforma y se habla de genéricos como:

-plataforma para movilizarse en contra del proyecto de 'fracking'

-opositores a la extracción de gas mediante la técnica conocida como 'fracking'

-plataforma en contra del sistema de fractura hidráulica para la obtención de gas en Euskadi.

- plataforma ciudadana constituida para evitar que se concedan estas autorizaciones

-grupos sociales y ecologistas que han mostrado su oposición a la utilización de la fracturación hidráulica

-asociaciones ecologistas y plataformas de defensa del territorio

Con relación al estudio de las fuentes citadas en las noticias analizadas, de los 245 textos analizados (se han descartado 9 textos por no disponer de fuentes), un total de 174 mencionan exclusivamente fuentes con una posición anti fracking, en 19 de ellos sólo figuran las fuentes con una perspectiva favorable y en 35 informaciones se integran fuentes pertenecientes a ambas perspectivas. En los textos que muestran la mirada contraria a la técnica de extracción del gas por fracking surgen 7 tipos de fuentes: políticos, ecologistas (incluidas las plataformas antifracking analizadas), expertos, sindicatos, famosos, particulares y asociaciones sin especificar su naturaleza. La fuente más referida es la formada por los políticos, citados en 101 ocasiones. Le siguen los grupos ecologistas, que aparecen en 87 ocasiones. Los expertos son nombrados en 6 , los sindicatos en 5, los famosos en 2, las asociaciones y particulares en 1 cada uno. En cuanto a las informaciones que acuden a fuentes favorables al fracking, son 3 los agentes informativos nombrados: políticos, empresas y expertos. De 
todas ellas la más habitual es la política, a la que se alude en 12 ocasiones. Las empresas defensoras de la técnica aparecen en 7 casos y los expertos en 3 .

Por lo que respecta a los relatos informativos que presentan ambas perspectivas, las referencias a políticos resultan mayoritarias, con 28 menciones, seguidas por ecologistas (con 24 referencias), por las empresas, en 17 ocasiones, expertos en 10, sindicalistas en una ocasión y el fiscal en otra.

\section{Conclusiones}

Las plataformas antifracking analizadas cumplen con su función de proporcionar información, sobre todo en relación a la llamada a la acción y la posibilidad de la participación ciudadana. Algo, lógico de esperar en este tipo organizaciones.

La subdimensión más descuidada es la referida a la identificación de las plataformas: resulta difícil ver organigramas y nombres propios, ya fueran de personas o colectivos. Es este un campo en el que se debería mejorar en aras de la transparencia.

Respecto a las dimensiones relacionadas con los medios de comunicación, se evidencia la falta de estrategias que garanticen una comunicación bidireccional. Se limitan a elaborar notas de prensa en el tradicional modo direccional de la fuente al medio.

La mitad de las plataformas analizadas tienen presencia en los medios. Algunas de manera testimonial (Asamblea de Burgos o Kuartago contra el Fracking); otras protagonizando la mayor parte del debate sobre el fracking en los medios analizados: Fracking Ez Araba (No al Fracking en Álava) y la Asamblea contra la Fractura Hidráulica de Cantabria, denominada oficialmente en su website Fractura Hidráulica No de Cantabria. Las otras ocho analizadas no han aparecido lo que puede indicar que el carácter local de estas plataformas limita su aparición en los diarios nacionales sin ediciones regionales. De ahí las escasa apariciones en medios como eldiario.es o publico.es. también por este condicionante local, en muchas ocasiones no se utiliza el nombre completo de la plataforma, 
obviando su demarcación geográfica que aparece claramente delimitada en la información.

En el período analizado predominan los relatos informativos que dan vOz a fuentes con una mirada contraria a la técnica del "fracking". En este sentido, las fuentes de carácter político son las citadas con mayor frecuencia por delante de los colectivos ecologistas. Los textos informativos que emplean como fuentes agentes a favor del "fracking" resultan minoritarios. De nuevo las fuentes de naturaleza política son las más habituales.

En las informaciones elaboradas con fuentes que exponen ambos puntos de vista, el contrario y el favorable al "fracking", son nuevamente los agentes políticos los más nombrados. Frente a la presencia de las plataformas en los medios, es necesario destacar la casi nula referencia directa de los parlamentarios españoles a cualquiera de las plataformas antifracking en las diversas sesiones que en las Cortes Generales se han celebrado para abordar la cuestión.

En definitiva, las plataformas ciudadanas constituidas para luchar con el fracking han conseguido visibilidad y atención mediática, apareciendo en cerca de un tercio de las informaciones que informaban sobre el tema. Fracking Ez Araba se felicita en su website de que Vitoria fue declarada "por fin" el 31 de mayo de 2013 Municipio Libre de Fracking (MLF). De esta forma, la capital alavesa se une a la campaña iniciada por Fracking Ez Araba en febrero de 2012. Sin embargo, son los políticos las fuentes más frecuente lo que muestra que continúan siendo, también es este asunto, los actores principales en el discurso informativo.

\section{Referencias bibliográficas}

Baviera Puig, T., y Civera Jorge, M. Weblogs. (2013), en López, G. (Ed.), Cibercomunidad. El espacio de la comunicación en la Comunidad Valenciana. Valencia, España: Tirant Humanidades, p. 85-102.

Briongos, R. y Arce, G. (2013). Para España sería una bendición hallar gas y petróleo usando el fracking. Diario de Burgos [en línea] 28 de mayo de 2013. Recuperado de http://www.diariodeburgos.es/noticia/Z12805128-D01AD57D- 
97779D77E916954B/20130528/españa/seria/bendicion/hallar/gas/petroleo/ usa ndo/fracking. Fecha de acceso 3 junio 2013.

Dader, J. L. \& Ayuso, I. D. (2008). « Las webs de partidos españoles 20042005: una investigación preliminar y de comparación europea, con una propuesta metodológica », en Canel, M. y Gurrionero, M. (eds.). Estudios de comunicación política. Libro del año 2008. Madrid: Facultad de Ciencias de la Información de la Universidad Complutense-ACOP, p. 419-444.

Dader, J. L. (2009). "Ciberpolítica en los websites de partidos políticos: La experiencia de las Elecciones de 2008 en España ante las tendencias transnacionales", Revista de Sociologia e Política (Brasil), $\mathrm{n}^{\circ}$ monográfico sobre "Internet y Política", vol. 17. nº 34.

De Landtsheer, C, Krasnoboka, N. y Neuner, C. (2001). « La facilidad de utilización de los web sites de partidos políticos. Estudio de algunos países de Europa del Este y Occidental » (1999). CIC. Cuadernos de Información y Comunicación, p. 107-162.

Igartua, J.J. (2006): Métodos cuantitativos de investigación en comunicación. Bosch. Barcelona.

Krippendorff, K. (1990). Metodología de análisis de contenido. Teoría y práctica. Barcelona: Paidós.

Mercado, MT; Àlvarez, À.; Herranz, JM. (2014). "The fracking debate in the media: The role of citizen platforms as sources of information", en ESSACHESS. Journal for Communication Studies, vol. 7, no. 1(13), pp. 45-62. Recuperado de http://www.essachess.com/index.php/jcs/article/view/234/260

Mercado, MT, Sánchez, S., Àlvarez, A. (2014). "Los científicos como actores y fuentes en el discurso mediático sobre la energía nuclear", en Prisma Social 12, pp. 544-580. Recuperado de

http://www.isdfundacion.org/publicaciones/revista/numeros/12/secciones/t emati ca/t-16-cientificos-energia-nuclear.html

Neuendorf, K.A. (2002): The content analysis guidebook. Thousand Oaks (CA): Sage Publications.

Ministerio de Industria, Turismo y Comercio (2013). Exploración y producción de hidrocarburos en España. Recuperado de http://www.minetur.gob.es/energia/petroleo/Exploracion/Mapa/Paginas/ma pSon deos.aspx. Fecha de acceso 23 de mayo de 2013. 
Nielsen, J, (2009). Press Area Usability. Recuperado de http://www.nngroup.com/articles/weblog-usability-top-ten-mistakes/. Fecha de acceso 14 de mayo de 2013.

Tyndal Centre for climate change research (2011). Shale gas: a provisional assessment of climate change and environmental impacts. Recuperado de http://www.tyndall.ac.uk/publications/technical-report/2011/shale-gasprovisional-assessment-climate-change-and-environmental. Fecha de acceso 28 mayo de 2012.

* Esta investigación forma parte del proyecto "Análisis del tratamiento informativo de las políticas energéticas en España, procesos de recepción y participación de organizaciones sociales" (Plan Nacional de I+D+i, referencia CSO2012-38363). 


\title{
La sociedad del Riesgo en la ficción televisiva tras el 11 de Septiembre. El caso de Homeland (Showtime, 2011) y The Walking Dead (AMC, 2010)
}

\author{
Delicia Aguado Peláez - Universidad País Vasco - \\ deliciaaguado@gmail.com
}

Resumen: Las tesis de Ulrich Beck cobran más vida que nunca tras los atentados del 11 de septiembre de 2011. Pues, tras ellos, se abre la puerta a ese discurso que encumbra la Seguridad por encima de Derechos y Libertades basándose en el riesgo. Una sociedad que teme volver a ser atacada por un enemigo incierto dibujado a golpe de estereotipos a través de alegatos políticos y de representaciones mediáticas. En este segundo escenario es en el que se mueve la presente investigación, que analiza cómo la ficción televisiva, en un momento dulce en su Tercera Edad Dorada, refleja esta sensación de miedo surgida tras los ataques. Para ello se hace uso de dos dramas de la televisión por cable de EEUU con diferente apego a la realidad. Por un lado, la vuelta a la paranoia terrorista de Homeland y, por otro, el holocausto zombi desarrollado en The Walking Dead.

Palabras clave: 11S; Ficción; Homeland; Sociedad del Riesgo; series de televisión; The Walking Dead. 


\section{Introducción}

Q IN IMPORTAR el rincón del globo en el que cada cual se $\checkmark$ encontrara aquel 11 de Septiembre de 2001 existe una cierta sensación de haber presenciado en persona el atentado contra el simbólico Word Trade Center. $\mathrm{Y}$ es que el primer gran ataque en suelo del gigante norteamericano va también a ser el primero en ser difundido en riguroso directo, haciendo de las propias cámaras de los viandantes los ojos de la comunidad internacional. Testigos que envían planos inestables desde todos los puntos de la catástrofe que, casi de forma inevitable, trasladan al espectador a un espectáculo pseudoficticio, como si de un metraje encontrado se tratara. Un caos que tantas y tantas veces había sido imaginado y recreado por la gran y la pequeña pantalla. Una sobredimensión mediática que deja grabada en la retina de los estadounidenses el dolor del trauma pero cuyas repercusiones van a actuar como tentáculos hendidos en el corazón de la política internacional.

Y es que la Administración Bush no tarda en anunciar su particular Guerra contra el Terror. La política que desata incursiones militares contra los países tachados como eje del mal y que justifica la creación de Guantánamo o la implantación de la Ley Patriota. Todo ello tras un discurso que dibuja, a través de un cóctel de estereotipos, un enemigo incierto capaz de lanzar un ataque inminente y que justifica la necesidad imperante de salvaguardar esa Seguridad resquebrajada aquel 11S. Aunque en ese intento se hayan de lacerar dos de los principios fundamentales de los que hasta entonces había hecho gala los EEUU: la Libertad y los Derechos.

Esta forma de proyectar las decisiones políticas en base al riesgo como amenaza futura nos lleva a aquel concepto que Ulrich Beck denomina ya en 1986 como Sociedad del Riesgo: "[...] el pasado pierde la fuerza de determinación para el presente. En su lugar aparece como "causa" de la vivencia y la actuación presentes el futuro, es decir, algo no existente, construido, ficticio" (2002: 48). De esta forma, las comunidades quedan supeditadas a un miedo que modifica las reglas del juego ya que son ligadas a la supremacía de la incertidumbre. Por consiguiente, para el autor, "lo que destruye las instituciones occidentales de la libertad y la democracia no es el acto terrorista, sino la escenificación global del mismo, así como las 
subsiguientes anticipaciones, acciones y reacciones políticas" (2008:28). Y es que con el $11 \mathrm{~S}$ se abre "un nuevo capítulo en la sociedad del riesgo mundial. Hay que distinguir claramente entre el atentado en sí mismo y la amenaza terrorista que el mismo universaliza", siendo lo decisivo "la percepción del mismo. Lo que los hombres temen que sea real es real en sus consecuencias" (Beck, 2001).

Justamente en esta teatralización tienen mucho que decir los medios de comunicación, no sólo desde la esfera informativa sino también desde el entretenimiento. No es algo casual que la propia Administración Bush pensara en la industria del cine como un buen aliado contra el terror (Faludi, 2009; Huerta, 2006). En este sentido, Miguel Ángel Huerta pone el foco sobre "[...] la importancia que tienen las películas como agentes configuradores de la percepción de la realidad, por un lado, y como documentos que nos sirven de testigos sociales y políticos, por otro" (Huerta, 2006: 18). Pero lo mismo podemos decir de un medio infiltrado en la mayoría de los hogares y que hoy en día está viviendo un momento de especial esplendor en torno a la llamada

Tercera Edad Dorada del Drama ${ }^{7}$ unas producciones que actúan como espejos de la realidad (Cascajosa, 2005, 2007; Frezza, 2009; Grandío, 2009;...). De esta forma, la recreación de la actualidad también está ligada a las referencias a esa amenaza latente, un manejo

\footnotetext{
${ }^{7}$ En la historia de la televisión se han identificado dos grandes épocas de esplendor del drama estadounidense. La Primera Edad Dorada se remonta a las décadas cuarenta y cincuenta con las antologías dramáticas en directo desde la ciudad de Nueva York. La Segunda fue definida por Robert Thompson (1996) para referirse a las series creadas en los años ochenta que arranca con Canción triste de Hill Street (Hill Street Blues, NBC, 1981-1987) y cierra con Twin Peaks (ABC, 1990-1991). Pero hoy ese momento de éxito vuelve a repetirse gracias a la apuesta por la calidad y la innovación devenido de dos grandes factores. Por un lado, la expansión del cable y el nacimiento de nuevas cadenas que rompen con las reglas establecidas, y su consecuente impacto en la forma de entender el juego de las hertzianas tradicionales -las networks ABC, CBS y NBC-. Por otro, el desarrollo de las nuevas tecnologías -desde Internet a las tabletas- que dotan al espectador de nuevos horizontes de consumo y le otorgan una mayor capacidad de interacción (Cascajosa, 2005; Tous, 2010).
} 
del miedo que Fernando de Felipe e Iván Gómez (2011) explican así en su Ficciones colaterales:

"Que el miedo sea el mensaje es algo que resulta especialmente preocupante cuando el canal elegido para ello es el de las emociones a flor de piel. Una piel que se vuelve peligrosamente fina e irritable en cuanto se tocan temas que tienen que ver con la identidad nacional, religiosa, étnica, ideológica, cultural o política. Como muchos especialistas se han apresurado a señalar, con 11-S de por medio o sin él, más que a un hungtingtoniano choque de civilizaciones, a lo que nos enfrentamos en la actualidad es a un auténtico choque de mentalidades (y hasta de imaginarios, añadiríamos nosotros)" (2011: 190).

Ya que este miedo no sólo crea un clima propicio para desarrollar una serie de medidas políticas y sociales sino que se cuela en el corazón de las instituciones estadounidenses, también en una tan fundamental como es la familia. Así, Susan Faludi afirma cómo parece que este trauma remueve el sentir de la olvidada Guerra Fría y lleva a los medios, el ocio y la publicidad a presentar la realidad post $11 \mathrm{~S}$ como "[...] una época que recuperaba los valores de los años cincuenta, la "unidad" de la familia nuclear, la feminidad en el hogar, la masculinidad que defendía la patria" (2009: 14). Es decir, esa supremacía de la seguridad desata un movimiento androcentrista donde los hombres vuelven a ocupar un lugar central en la sociedad ligado a la virilidad fuerte y protectora, mientras que las mujeres quedan en un segundo plano atadas a una imagen de feminidad débil y ligada al hogar.

En este sentido, el miedo y sus repercusiones en la representación de una sociedad que descansa en unos pilares conservadores es el punto de partida del presente texto. Para ello, vamos a acercarnos a dos series de televisión por cable fundamentales en esta Tercera Edad Dorada y que están fuertemente marcadas por el post $11 \mathrm{~S}$ a pesar de su diferente apego a la realidad. La primera de ellas es Homeland (Showtime, 2011-), heredera de la lucha antiterrorista de Jack Bauer (Kiefer Sutherland) en 24 (Fox, 2001-2010), y en la que Carrie Mathison (Claire Danes) se sumerge en un juego de espejos en la que nadie parece ser lo que parece. Mientras que la segunda, totalmente 
alegórica, recrea la lucha por la supervivencia de un pequeño grupo de personas en un postapocalipsis zombi en The Walking Dead (AMC, 2010-).

\section{Metodología}

El objetivo principal de la presente investigación se centra en analizar estas dos ficciones televisivas atendiendo al impacto de dos de las grandes consecuencias del 11S: el clima del miedo y el conservadurismo. Es decir, nos centramos en una serie de preguntas de investigación como son ¿Qué temas recurrentes se pueden encontrar en estos dramas? ¿Qué mensajes manifiestos y latentes nos encontramos? ¿Existe un discurso ligado al miedo? ¿Cómo se representa? ¿Hay una presencia de un discurso marcado por el conservadurismo? ¿Cómo se representa el sistema político y social? ¿Qué rol cumple el liderazgo? ¿Y el heroísmo? ¿cómo son representadas las mujeres?

¿Cómo influye el Post 11S en estas series? De esta forma, partimos de la hipótesis general que afirma que: "El Post 11S tiene una influencia directa en Homeland y en The Walking Dead a través de una trama marcada por el miedo y el conservadurismo".

Para ello se hace uso del Análisis de Contenido, una técnica que nos permite detectar "la emergencia de aquel sentido latente que procede de las prácticas sociales y cognitivas que instrumentalmente recurren a la comunicación para facilitar la interacción que subyace a los actos comunicativos concretos y subtiende la superficie material del texto" (Piñuel, 2002: 4). Es decir, conocer los mensajes explícitos y latentes que se encuentran y relacionarlos con su contexto. Todo ello desde un enfoque cualitativo al entender que, como explica José Ignacio Ruiz Olabuénaga: "La flexibilidad, la adaptabilidad, la singularidad concreta, la proximidad, el pluriplanteamiento de los que hacen gala los métodos cualitativos son, todavía, más adecuados para el análisis de contenido" (2012: 233).

De esta forma, se toman como unidades de análisis los 36 capítulos de Homeland emitidos a través de las tres primeras temporadas ${ }^{8}$, así

${ }^{8}$ Doce episodios por temporada. Primera estrenada en 2011; Segunda en 2012; Tercera en 2013. La cuarta temporada está en emisión en el momento en el que 
como los 51 de The Walking Dead correspondientes a las cuatro primeras 9 . Se presta especial atención a un grupo de categorías articuladas en dos grandes dimensiones vinculadas al contexto sociopolítico. Estas son, por un lado, la recreación de un ambiente siniestro y, por otro, la representación de una sociedad conservadora.

La primera está sujeta a aquellos aspectos lúgubres, siniestros o inquietantes que crean una sociedad marcada por la incertidumbre ante la amenaza de un ataque inminente producido por un enemigo incierto. Una dimensión construida a través de tres grandes categorías. La primera está ligada a la sensación de un ataque inminente -bien sean ataques terroristas, paisajes postapocalípticos, elementos tenebrosos, acciones basadas en el miedo o placeres o libertades que pongan en peligro el bienestar-.

La segunda, por su lado, se basa en la construcción de la otredad, prestando especial atención a la unión del Nosotros -como forma de creación de identidad grupal y diferenciando entre aquella unión devenida de la convivencia y la que es fruto de un ataque exterior- y a su confrontación con Ellos -el Otro- prestando especial atención al juego con la desconfianza y miedo-.

Por último, en torno al uso de la violencia se atiende a la representación - aparición y consecuencias, así como al tratamiento visual explícito de la sangre, amputaciones o vísceras-; el tipo asesinatos, peleas, tortura, violaciones-; el fin -a quién va dirigida, si se da dentro o fuera del grupo, así como el fin de la misma: ataque, defensa, información, luchas de poder, venganza...-.

La segunda dimensión está íntimamente ligada a la anterior y se basa en el estudio de la representación de la sociedad, prestando especial atención a los juegos de poder entre grupos. Sus categorías son, por un lado, el estudio de la estructura de la sociedad y el liderazgo

se realiza la presente investigación, por lo que no está en el centro del análisis aunque se hará alguna referencia que se considere relevante

${ }^{9}$ Primera temporada, año 2010, 6 episodios; Segunda temporada, año 2011, 13 episodios. Tercera temporada, año 2012, 16 episodios; Cuarta temporada, año 2013, 16 episodios. Al que igual que ocurre con Homeland, la quinta temporada se está emitiendo actualmente, por lo que tampoco está en el centro del análisis aunque se haga referencia a ella 
atendiendo a la descripción del líder ${ }^{10}$-clase, edad, orientación sexual, procedencia, raza, sexo...-, al tipo de liderazgo -horizontal, vertical-, el modelo de toma de decisiones -unipersonal, cesión de poder, participativo-, la forma de mantener el poder -autoritarismo, consenso, luchas de poder, dependencia-, los grupos de confianza miembros, perfil, rol-, así como la construcción del héroe características, tipo de heroísmo, acciones-. Cabe destacar que en el caso de Homeland este apartado está basado en relaciones de poder profesionales y personales mientras que en The Walking Dead se realiza un estudio más centrado en el grupo.

Atendemos a la categoría la representación de los hombres y las mujeres en su distribución espacial pública y/o privada. En este sentido, se lleva a cabo un perfil físico -edad, apariencia-, social -clase, profesión, habilidades sociales- y psicológico. Este último atendiendo a su carácter, debilidades y fortalezas, relación con su entorno, toma de decisiones... en torno a una serie de indicadores como son: acierto; agresividad; amistad; amor romántico; autoridad; causa de la problemática; crueldad; cuidados; defensa, dependencia, desconfianza; desesperación; diálogo; disputas; dominio; emotividad; empatía; error; espera; familia; fraternidad; fuerza; independencia; infravaloración; iniciativa; inteligencia; intuición; irracionalidad; liderazgo; locura; maternidad; miedo; necesidad de protección; profesionalidad; religión; seguridad; sexo; suicidio; sumisión; superficialidad; supervivencia; pacifismo; paternalismo; paternidad; posesión; táctica; tareas del hogar; tareas físicas; uso de armas; violencia; virilidad.

\section{Análisis}

A partir de aquí se pasa a analizar las dos series señaladas en ambas dimensiones. Cabe señalar que se desvela gran parte de la trama, incluyendo la cuarta temporada de Homeland y la quinta de The Walking Dead.

\footnotetext{
${ }^{10}$ Tomando como referencia a Carrie (Homeland) y a Rick (The Walking Dead) y sus compañeros o antagonistas.
} 


\subsection{La vuelta al terrorismo: Homeland}

El canal norteamericano por cable Showtime apuesta por una adaptación de la exitosa ficción israelí Hatufim (Channel 2, 2010-) desarrollada por Gideon Raff. Precisamente es el hierosolimitano Raff el encargado de recrear para 20th Century Fox Television este drama bajo el nombre de Homeland, contando con la colaboración de Howard Gordon y Alex Gansa -ambos productores y guionistas de 24 (Fox, 2001-2010)-. Una serie que consigue el aplauso de la crítica con, entre otros, un Globo de Oro a mejor drama.

Tras los atentados del 11S muchas series incorporan en sus tramas alusiones más o menos directas a este hecho histórico. Producciones como Turno de guardia (Third Watch, NBC, 1999-2005), protagonizada por bomberos, personal de emergencias y policía de Nueva York, han de afrontar la incorporación de este doloroso momento a través de alusiones u homenajes (Cascajosa, 2005). Mientras tanto, otras, como 24, endurecen su argumento en una línea más cercana a la Guerra contra el Terror enfrentando al héroe a un mundo lleno de conspiraciones y ataques masivos y justificando todo tipo de acciones en nombre de la Seguridad. Aunque pudiera parecer algo atado a la inmediatez, ambos modelos quedan suspendidos en el tiempo y continúan vigentes. De esta forma, la primera tendencia da lugar a historias emotivas como Touch (Fox, 2012-2013), en la que Martin Bohm (Kiefer Sutherland) recibe la noticia de que no ha sido posible rescatar los restos de su esposa, fallecida en las Torres Gemelas, y que, a lo largo de mágicos acontecimientos, conoce los últimos momentos de su vida antes del atentado. Mientras que la segunda da lugar a la serie que aquí nos ocupa. Once años después, Homeland vuelve a ese clima explícito de riesgo donde la amenaza de un ataque en suelo estadounidense proviene de un enemigo incierto ligado al mundo árabe. Aunque, en esta ocasión, la idea se narre a través de un sinfín de juegos de espejos.

\subsubsection{Dimensión I: La pertinaz sombra de la islamofobia}

A este respecto, la primera categoría, recreación de una sensación de riesgo, tiene un peso fundamental ya que es el propio centro de una trama que gira en torno a la sospecha y la invisibilidad del enemigo. 
De esta manera, todo comienza cuando Carrie Mathison ${ }^{11}$, una oficial de operaciones de la CIA, es informada de que un prisionero de guerra cambia de bando. Una filtración que coincide con el regreso del sargento Nicholas Brody (Damian Lewis) recientemente liberado tras soportar ocho años de cautividad en manos de miembros de Al Qaeda y que regresa a EEUU convertido en un héroe nacional. La mezcla de política y espectacularidad mediática, hacen que las sospechas de Carrie sean ignoradas de forma oficial, pero la tenacidad, casi obsesiva, de la agente la lleva a iniciar una investigación que traspasa la legalidad ${ }^{12}$. Todo ello justificado por la necesidad de no fallar a un país con un tema que desata los miedos más profundos del corazón estadounidense. Precisamente el enemigo dibujado como un supuesto héroe infiltrado en el Ejército, primero, y en el Congreso, después, codeándose con la élite institucional norteamericana, es parte de la construcción de ese enemigo incierto.

Asimismo, este miedo aparece ligado a la segunda categoría, la otredad, ya que "[...] el mal es ante todo el Otro, el suicida capaz de matar en nombre de Alá, de sacrificar su único valor; la vida" (Erreguerena, 2002). De esta forma, lo primero que se construye es un Nosotros a través del patriotismo y la exaltación del sentimiento nacional. Algo que se crea con la repetición de elementos simbólicos unidos a momentos de gran carga emocional -el águila calva, el himno nacional, instituciones o localizaciones emblemáticas, parafernalia militar y, por supuesto, la Old Glory-; de referencias a la nación relacionándola con libertad y grandeza -como mundo libre-; así como una vinculación con ese cristianismo tan apegado a la política estadounidense en conversaciones y discursos.

El Nosotros es construido, además, a través de la protagonista de la serie, pues Carrie simboliza a la vez el trauma, la actitud defensiva y el

${ }^{11}$ A partir de aquí utilizaremos el nombre de pila de la protagonista para referimos a ella, ya que es el que utilizan mayoritariamente en la serie para referirse a ella. Un hecho significativo en torno a la construcción del género pues que la mayoría de personajes masculinos son tratados por su apellido Brody, Estés, Quinn-.

${ }^{12}$ Todo comienza cuando Carrie instala cámaras de video vigilancia en casa de Brody. Una violación a su intimidad guiada por la esperanza de obtener información sobre el ataque y quequeda amparado bajo la integridad moral de la heroína. 
deseo de mirar al futuro de la sociedad estadounidense. Así, el espectador ve, en un primer nivel, como la agente se define a través del sufrimiento que arrastra por los fallos cometidos aquel 11S. En un segundo plano, conoce a una heroína totalmente entregada a su profesión y a su patria -hasta el punto de descuidarse física y emocionalmente-. Inteligente y trabajadora, su determinación de frenar cualquier ataque la llevan a tener una concepción maquiavélica de la democracia, justificando cualquier vulneración de los derechos en pro de la seguridad. Pero, paradójicamente, también va a conocer a una mujer emotiva y ética. Una joven capaz de denunciar las corruptelas internas de un sistema política y moralmente denostado, así como a enamorarse del propio Brody, al ser la única capaz de entender el dilema entre héroe y villano de este personaje. Una triple tensión entre dolor, dureza y empatía que se va modelando a través del trastorno bipolar que sufre la protagonista. Una enfermedad que juega un papel fundamental en la intriga cuando sus compañeros -y el propio público- duden de la credibilidad de su razón; una pieza más de la incertidumbre de un país en el que las fronteras de la realidad se difuminan.

De esta forma, la tercera construcción del Nosotros es la más ligada a la citada Guerra contra el Terror. Es decir, la de los dos bandos de la guerra donde los estadounidenses conforman ese Nosotros: los buenos, los patriotas, los defensores de la democracia contra un Ellos: malvado, terrorista, que sólo buscan el fin de la democracia. Una concepción maniquea de la realidad que justifica ese escenario de amenazas, chantajes, conspiraciones, encubrimientos, espías y torturas en las que el FBI, la CIA y el propio gabinete presidencial forman parte con total normalidad siempre bajo el amparo de la Seguridad $^{13}$.

\footnotetext{
${ }^{13}$ Este tipo de prácticas son una constante. Así, Carrie busca la colaboración de un diplomático saudita a través de la coacción. Cuando nada funciona amenaza con extraditar a su hija: "We would deport her [...] We would make sure that she had no choice but to go back to Saudi Arabia and get fat and wear a burkha for the rest of her miserable life" (1x10 Representative Brody). Una muestra de la forma de actuar de la CIA, así como de la representación de Occidente en contraste con Oriente.
} 
Y entre el Nosotros y el Ellos, hay que detenerse en un personaje que ejerce de puente entre ambos mundos, justamente el principal motor de la construcción de lo siniestro: Brody. A través de los ojos de Carrie y de caóticos flashbacks, el espectador va a ver como el padre y patriota envuelto en banderas sufre una progresiva construcción hacia la otredad, hacia el antiheroísmo. Es decir, lo que, dentro de la cultura del miedo, Raquel Crisóstomos Gálvez define como enemigo doméstico:

"Este discurso son los cimientos sobre los que se sostiene el nuevo enemigo domestico, nacido y criado dentro del concepto de patria, pero que se rebela contra ella. Sin la idea de terror contra una abstracción y la recuperación de la dualidad a través de ella, no sería posible que el enemigo que atenta contra los intereses propios y que hay que descubrir a través de una atenta vigilancia se hubiera fortalecido de tal manera hasta alcanzar los atributos del héroe, como sucede en Dexter y en Homeland" (2013: 8).

En un primer escalón, la narración de las torturas que debe soportar y su conversión al Islam -rodeada siempre de oscurantismo- hacen ver que el marine se rompe ante sus captores. Pero en un segundo nivel, el público asiste a cómo el terrorista Abu Nazir (Navid Negahban) pasa a acercarse al derrotado Brody a través de la emotividad. De hecho, le ofrece dar clases de inglés a su propio hijo, Issa (Rohan Chand), con quien llega a tener una gran complicidad. Ese cariño es justo lo que doblega por completo al marine que no soporta ser testigo de su muerte, junto con decenas de niños, en un ataque a un colegio ordenado por el vicepresidente de los EEUU, William Walden (Jamey Sheridan) -una operación que nunca ve la luz en los medios de comunicación- (109 Crossfire). De esta forma, se dibuja a un Brody lejos del estereotipado rol de terrorista que es un hombre cruel, fanático religioso y que odia a los EEUU ${ }^{14}$. Todo lo contrario,

\footnotetext{
${ }^{14}$ Otros norteamericanos también cambian de bando manipulados por Nazir y su equipo, como el también marine Tom Walker (Chris Chalk) o la joven Aileen Morgan (Marin Ireland). Todos ellos rotos en base a torturas físicas o al dolor sobre actos injustos y muestran, a lo largo de la trama, dudas o, incluso, arrepentimiento. Lo contrario a personajes procedentes del mundo islámico que están totalmente convencidos de sus actos y son impasibles.
} 
sigue siendo un patriota y un padre que está dispuesto a dar su vida por lo que considera una causa justa. Un momento que se simboliza en la grabación que deja antes de perpetrar el atentado contra el hombre que considera responsable de la muerte de Issa ${ }^{15}$. Brody no es un villano, es sólo una víctima más del terrorismo. Una idea que guarda relación con una frase pronunciada por el propio Nazir al preguntarse: "¿Por qué matar un hombre, cuando se puede matar una idea?" "16. De esta forma, Cuadrado Alvarado explica cómo Brody nos traslada al imaginario del héroe americano como purificador de las instituciones:

"El monomito americano es la fuente del modelo de virilidad masculina que combina dos ideales aparentemente contradictorios de la masculinidad: el ethos puritano y el mito de la frontera (Holt \& Thompson, 2002). Por un lado estaría el americano que alcanza respeto y valor como hombre contribuyendo a la forja de la sociedad a través de su esfuerzo en la comunidad, en la familia, mediante el trabajo duro y colaborativo, que respeta las reglas y cuyo esfuerzo le lleva a la prosperidad y la riqueza. Su triunfo además se mide en el puesto que alcanza en su entorno como referencia moral. Y por otro lado nos encontramos al hombre populista, que lucha contra el dogma político y la autoridad, hombres hechos a sí mismos en un territorio virgen donde las oportunidades son limitadas. Esta figura entiende que la tarea de convertirse en un hombre es un proyecto competitivo y agresivo" (2013: 36).

A partir del cierre de la primera temporada, la otredad de Brody se va desdibujando paulatinamente convirtiéndose en la viva imagen del

15 "People will say I was broken; I was brainwashed. People will say I was turned into a terrorist, taught to hate my country. I love my country. What I am, is a Marine. Like my father before me, and his father before him. And as a Marine, I swore an oath to defend the Untied States of America against enemies both foreign and domestic. My action this day, is against such domestic enemies. The Vice President, and members of his national security team, who I know to be liars and war criminals. Responsible for atrocities they were never held accountable for. This is about justice, for 82 children. Whose deaths were never acknowledged, and whose murder is a stain on the soul of this nation" (1x12 Marine One)

16 “Why kill a man when you can kill an idea?' (1x12 Marine One) 
desacierto de ambos mundos y, por lo tanto, en un objetivo para estadounidenses y árabes. Cabe señalar como, tras su fuga de toda la tercera temporada -con escenarios tan emblemáticos para la otredad como Venezuela- acaba redimiéndose por su país y muriendo en manos de los Otros, en Irán, aunque nadie en los EEUU va a reconocer su heroísmo, excepto Carrie (312 The Star). El Ellos está representado por el terrorismo islámico y siempre a golpe de estereotipos. El fundamentalismo islámico se convierte así en el Otro cuyo objetivo es dinamitar los pilares de la sociedad americana. Así, Juan Rey explica esta confrontación entre Occidente y Oriente en esta polaridad: "Nosotros somos la encarnación de todas las virtudes (libres, demócratas, desarrollados, modernos) y ellos, en cambio, el cúmulo de todas las maldades (esclavos, súbditos, atrasados, arcaicos)" Es decir, "A partir de esta visión maniquea, el musulmán, extinguidos o dominados los otros adversarios de Estados Unidos, ha pasado a simbolizar al moderno Satán" (Rey, 2004: 85). Un esbozo del enemigo que queda representado en una amenazante cita de Abu Nazir:

"Generation after generation must suffer and die. We are prepared for death. Are you? [...] With your pension plans and organic foods, your beach houses and sports clubs. Do you have the perseverance, the tenacity, the faith? Because we do [...] We carry God in our hearts, our souls. To die is to join him. It may take a century, two centuries, three centuries... but we will exterminate you" (2x10 Broken Hearts)."

En general, una representación estándar que mezcla conceptos -sin diferenciar fundamentalismo, islámico, salafismo, yihadismo...-, procedencia -Oriente Próximo, norte de África...-, razas -árabe, persa...- y religión. Pues el Islam se liga constantemente a la confrontación y la justificación de la violencia al tener un gran peso en la creación del ambiente siniestro y de la otredad. Algo que puede verse a través del discurso estereotipado del terrorismo y de la conversión de Brody.

Y es que, de nuevo, Brody funciona como un puente. Por un lado, se normaliza al mostrar su conversión como un acto de fe individual capaz de destapar los clichés negativos a los que está sujeta de cara a 
la sociedad norteamericana ${ }^{17}$. Por otro, el secretismo y el oscurantismo al que se liga su práctica es uno de los motores de la incertidumbre.

Por último, cabe destacar que la violencia en Homeland tiene importancia en tanto a que es utilizada para conseguir un fin concreto. Siempre que sea manejada por un ser éticamente consolidado -Carrie o Saul Berenson (Mandy Patinkin)- se entiende como justificada. Cuando está en manos del terrorismo islámico o de ciertos individuos corrompidos del sistema norteamericano, reprobable ${ }^{18}$.

\subsubsection{Dimensión II: Cuando el amor arrastra a la irracionalidad}

El liderazgo real encaja con el normativo sujeto político que denuncia la teoría feminista: varón, adulto, blanco -exceptuando Estes que es afroamericano-, burgués, heterosexual, occidental y sin discapacidades (Amorós, 1985; Miyares, 2003; Pateman, 1995). Aún así, el único personaje femenino que destaca es justamente la heroína de la trama. Por ello, Carrie va a ser el centro del estudio en torno al liderazgo, analizando el resto de figuras en relación con ella.

Esta estudiante de lenguas árabes es reclutada como agente de la CIA, un mundo primordialmente masculino en el que rompe con la normalidad en dos grandes planos: el propio hecho de ser mujer y el de tener una enfermedad crónica -parte inherente a la vez de la incertidumbre y de la propia feminidad en sí-. Pese a ello, sigue

${ }^{17}$ Así, por un lado Carrie comprende el valor espiritual de su conversión y su hija Dana (Morgan Saylor) siente curiosidad por ella -llegando a hacer público que su padre es musulmán, harta de comentarios xenófobos, ante la irrisión de compañeros (2x01 The Smile)-. Mientras, por otro su esposa Jessica (Morena Baccarin) no es capaz de aceptarla y llega a espetar: "These are the people who tortured you. These are the people who, if they found out Dana and Xander were having sex, they would stone her to death in a soccer stadium" y, tras tirar al suelo el Corán le advierte: "I married a US Marine. This can't happen. You have a wife, two kids. You are a Congressman in the running to be Vice President. It cannot happen. You get that, right?" (2x01 The Smile).

${ }^{18}$ De esta forma, el Vicepresidente Walden, responsable del asesinato de Issa, queda retratado como un megalómano, manipulador y sin escrúpulos, algo que incluso justifica su asesinato a manos de Brody (2x10 Broken Hearts). Lo mismo ocurre con David Estes (David Harewood). 
siendo blanca, estadounidense, heterosexual, de clase acomodada y físicamente integrada en los estándares de belleza occidental - ojos claros, rubia, delgada...-.

A pesar de su puesto, este personaje está construido en torno a los cánones de la feminidad normativa. De esta forma, siempre que se rompe con esta sistematicidad a través de una mayor capacidad para la acción, de la toma de decisiones, de su mentalidad maquiavélica o de una razón más abstracta, se compensa con mayores dosis de emotividad, empatía, irracionalidad, sensualidad, sexualidad o amor. Es decir, la divisoria generizada impuesta por el patriarcado se reproduce en este personaje.

Esto explica como la agente destaca por su marcada intuición cuando toma decisiones, a pesar de que también aplique su inteligencia o su capacidad táctica. Una intuición ligada a lo femenino que, como explica Sara Mateos Sillero, "proviene de la maternidad potencial, sea ejercida o no" (2013: 306). Maternidad que ya Rousseau ligaba a la naturaleza como parte del orden simbólico femenino: "La consecuencia de este esencialismo es que se configura el sentido de la vida de las mujeres en una única opción universal director del centro de contraterrorismo, que muestra en más de una ocasión sus ganas de medrar en base al juego sucio. Unas intrigas que continúan en la cuarta temporada donde el director de la CIA, Andrew Lockhart (Tracy Letts), cae fácilmente ante los chantajes de Carrie o esposo de la embajadora paquistaní se ve obligado a pasar información al ISI servicio de inteligencia paquistaní- para tapar malas conductas pasadas para el sexo femenino por el hecho de serlo, negando ontológicamente a la mujer como individuo, como sujeto" (2013: 307). Lo mismo ocurre con su mentalidad maquiavélica o su razón abstracta que se ve continuamente minada por su amor incondicional a Brody.

$\mathrm{Y}$ es que justamente el amor y el sexo son una constante en la construcción de este personaje ${ }^{19}$. Carrie realiza un primer acercamiento al marine con el único fin de obtener información del

${ }^{19}$ Desde el inicio, se narra la pasada aventura que narra con David Estes, el director del centro de contraterrorismo de la CIA, y que termina con su matrimonio. 
supuesto terrorista, un encuentro que termina en una primera y embriagada relación sexual. La construcción de la agente como femme fatale se desdibuja cuando paulatinamente se va enamorando del hombre al que investiga. Pese a ello, la unión entre mujer y espionaje se relaciona en diferentes ocasiones con el amor y el sexo a lo largo del desarrollo de la trama, siendo varias las ocasiones en las que su equipo es testigo de la manipulación de Carrie haciendo uso de $\operatorname{ambos}^{20}$. Un uso de la sexualidad en las mujeres de la que Shelby C. Murray, en su estudio sobre Homeland, advierte que, aunque pueda parecer una herramienta del empoderamiento femenino no es más que una forma de reforzar la supremacía masculina:

"Although it may seem empowering to use sexuality as a weapon gain control over men, women are actually just reinforcing hegemonic masculine supremacy, and therefore, striping themselves of power overall. By using sexuality as a tool, women are giving into a maleconstructed ideal of women as a sexual object and, therefore, are playing by the rules of masculine supremacy. Although the male may seem vulnerable in this situation, the implications that women are sex objects is exactly what makes women in these situations fall prey to patriarchy. This age-old gender stereotype, utilized frequently in media, of sexually appealing women getting what they want with their looks and sexuality, not only creates a false sense of empowerment, but it also creates a harmful gender script for women" 21 .

Más peso que el sexo lo tiene el amor. A pesar de lo que significa personal y profesionalmente para ella mantener un affaire con el hombre que investiga por terrorismo, Carrie se involucra sentimentalmente con Brody. Un hombre que no duda en manipular, mentir y tergiversar la realidad, y que trata con desdén a la

${ }^{20}$ Así, durante el interrogatorio a Brody reconoce estar enamorada de él para conseguir que confiese ante sus compañeros (205 Q\&A); mantiene relaciones sexuales con Brody, también con sus compañeros tras la video vigilancia (208 I'll Fly Away); o, lo que supone un regreso a la femme fatale durante el comienzo de la última temporada, con la manipulación a través del amor y el sexo de Aayan Ibrahim (Suraj Sharma), un joven estudiante de medicina (404 Iron in the Fire; 405 About a Boy; 406 From A to B and Back Again).

${ }^{21}$ Llegando a hacerla dudar de su propia estabilidad mental, algo que acaba en una terapia de electroconvulsiva (112 Marine One) o la actitud amenazante cuando destapa su traición (204 New Car Smell). 
protagonista jugando con dosis de violencia psicológica15 -algo que se repite con su esposa-. El amor romántico es central y es representado como problemático o tormentoso pero inevitable, aunque se considere un lastre de cara a su vida personal o al reconocimiento profesional de su propio equipo.

$Y$ es que Carrie va a ser cuestionada en diferentes ocasiones por la falta de rigurosidad a través de su relación con el marine. Algo ligado a una simetría romántica para Laura Antón: "La inestabilidad de la seguridad nacional que se asocia al objeto de investigación, y de amor, de la agente de la CIA, un marine traidor, se traduce en una creciente inestabilidad emocional del personaje femenino" (2014: 66). Una incertidumbre que también está sujeta a su desorden bipolar, al no poder distinguir los límites de la realidad con claridad. Y es que su enfermedad también está ligada a la normatividad femenina ya que, como explica esta autora, forma parte del precedente hollywoodense de la mujer gótica denominada por Mary Ann Doane como mujeres paranoicas y que se repite en esta narrativa (neo)noir (Antón, 2014). De esta forma, este neo-noir feminizante parodia el patrón clásico encadenando a la mujer como sujeto de deseo así como " se realza una cuestión, por definición, crítica y/o feminista: cuál es la función que cumple la mujer en la sociedad actual, es decir, qué significa hoy "ser mujer" (Antón, 2014: 80).

Otro de los límites de la expansión en el espacio público de Carrie se asocial al control de una figura paternal a través de los personajes Saul, Brody y Peter Quinn (Rupert Friend), tutores de las acciones y las emociones -por exceso o defecto- de la agente. De esta forma, Saul es el responsable de reclutar a

Carrie, su mentor y la figura más paterna. Empático, inteligente y sobrio, no duda en interferir en la política interna de países árabes para colocar aliados de dudosa ética, o en poner en riesgo física y psicológicamente a la protagonista para lograr sus objetivos. Pese a también jugar con los límites de la legalidad de sus actos, Saul no debe de hacer frente a cuestionamientos personales de su equipo aunque sí a luchas internas de poder-, algo que no ocurre con Carrie, siempre expuesta a objeciones de terceros. Algo similar ocurre con Quinn. Este agente de élite actúa como un mercenario pero sus actos sólo son puestos en cuestión por su propia moral. Aún así, se permite 
preocuparse de la frialdad y la pérdida de emotividad de Carrie, llegando a cuestionarla en privado y en público en diferentes ocasiones. Mención aparte para Brody, por el cual es capaz incluso de rechazar la reasignación en la CIA y su ascenso profesional. De esta forma, Diana Damean nos explica cómo, cuando una mujer ocupa el espacio público, los medios presentan un modelo distorsionado de esta emancipación femenina llevando la problemática al terreno personal:

"Each time a woman appears as independent, rational, successful, the stress is moved on her personal life (she has no partner, no children or is not attractive) so as to undermine her professional achievements. The cost for being "different" is too high and women are not willing to give up their femininity (beauty and motherhood) in exchange for liberation" (2006: 93).

En esta línea se encuentra el último pilar entre la masculinidad y la feminidad normativa: la maternidad. Desde el inicio, duda en seguir adelante con una gestación que no desea, aunque finalmente lo hace presionada por su familia. Una maternidad que es representada como algo doloroso y ajeno, como si el hecho de formar parte del espacio público la incapacitara para hacerse cargo del ámbito de los cuidados. Un aspecto que mortifica a la agente, especialmente a partir de la cuarta temporada y que nunca sería planteado si el personaje fuera un hombre.

Hasta aquí, hemos visto como el liderazgo de Carrie está totalmente sujeto a la construcción de una mujer que intenta colarse en el espacio público pero que es ajena al mismo, destacando continuamente las diferencias entre lo femenino y lo masculino. Atendiendo a la segunda categoría, vemos como, en líneas generales, esta imagen se repite una y otra vez. Aunque en muchas ocasiones sean papeles fuertes, independientes y ligados al mundo profesional, siguen también vinculados al amor romántico, a los cuidados, a la emotividad, la empatía, la inestabilidad emocional, la familia, la maternidad, o el sexo.

Cabe destacar la construcción de tres papeles femeninos construidos desde la antítesis de Carrie. En primer lugar, Jessica, la esposa de Brody, se configura como la perfecta esposa y madre, siempre 
vinculada al hogar pero capaz de ocupar el espacio público para apoyar a su marido. Una mujer que deja a su pareja sentimental cuando su esposo regresa de la muerte años después y que soporta estoicamente los abusos de un hombre traumatizado. En segundo lugar, su propia hermana, Maggie (Amy Hargreaves) también esposa y madre, consigue equilibrar su éxito profesional como psiquiatra curiosamente antagónica a la enfermedad de Carrie- y el cuidado de su vida familiar, en el que entra su hermana -y su sobrina después-. Y, por último, Fara Sherazi (Nazanin Boniadi), el único personaje árabe dentro del equipo de la CIA representada a través de la dulzura, emotividad, su preocupación por la familia y su alto nivel moral que la hacen chocar con Carrie en la última temporada.

Además, cabe destacar el papel del amor como centro en la vida de las mujeres en Homeland. Algo que es también representado desde el conflicto tanto para Carrie, como para Dana -con su relación adolescente con un chico que resulta ser un asesino-, Jessica -dejando a su amante y sometida a Brody-, Mira Berenson (Sarita Choudhury) -que no es capaz de que Saul se aleje de su vida profesional- y Martha Boyd (Laila Robins) - con una relación desgastada-.

El amor es, además, causa de irracionalidad en las mujeres. Si ya hablamos de Carrie y su relación con Brody; Jessica acoge a su esposo sin darse cuenta de que es un terrorista; Mira hace lo propio con un amante que resulta ser un infiltrado que sólo busca obtener información de su compañero; y la embajadora de Pakistan desconoce el papel de su marido filtrando información de vital importancia para la seguridad. Sujetas al espacio público o al privado todas ellas son cuestionadas desde su vida personal. Mención aparte para las mujeres árabes que están aliadas con terroristas, que sí están más ligadas a la crueldad y a la violencia, carcomidas por el sistema.

\subsection{La alegoría postapocalíptica: The Walking Dead}

$\mathrm{Y}$ de un drama totalmente ligado al terrorismo a uno que funciona como una alegoría de la realidad. La adaptación de las historietas homónimas de Robert Kirkman y Tony Moore relatan cómo Rick Grimes (Andrew Lincoln), un ayudante de sheriff de Kentucky, despierta de un coma en medio de un apocalipsis de muertos vivientes. Una apuesta de la cadena que se convierte en el programa 
estrella, llegando a ser el drama más visto de la televisión por cable con una audiencia en continuo crecimiento.

A diferencia de Homeland, esta serie no gira en torno al terrorismo y se aleja de la realidad gracias al género zombi. A pesar de ello, forma parte de unas ficciones que actúan como alegorías de la realidad que se cuela en unas tramas que se pueden permitir amplias licencias para contar lo que ocurre a su alrededor.

\subsubsection{Dimensión I: E1 pesimismo antropológico}

En una serie ligada al género de horror la primera categoría sobre la sensación de un ataque inminente es central aunque, al contrario que con la sutileza de Homeland, el terror explícito. Así, la recreación de un ambiente sin salida comienza con paisajes asolados, edificios institucionales destruidos bajo la sombra de una roída bandera americana, o imágenes de cadáveres amontonados por doquier. Un juego visible a través de una de las escenas del episodio piloto más emblemáticas: un solitario Rick a caballo, ataviado con armas y su atuendo de oficial de policía. Con el skyline de Atlanta al fondo, avanza por la despejada carretera de entrada a la ciudad, mientras que en la de salida se agolpan decenas de vehículos abandonados. Una tensión audiovisual que busca trasladar todos los sentidos del espectador a un putrefacto entorno sin salida en el que puede ser atacado por una horda de caminantes en cualquier momento. Una inseguridad que marca el día a día de los supervivientes y que no les permite bajar la guardia ya que al horror zombi también se suma la desconfianza a la raza humana. De hecho, es usual que lugares aparentemente seguros se conviertan en un infierno ${ }^{22}$ o que

\footnotetext{
${ }^{22}$ El viaje hacia el Centro de Control de Enfermedades simboliza el fin de la esperanza de encontrar una cura y el grupo debe escapar de su destrucción (primera temporada); la pacífica granja de Hershel Greene (Scott Wilson) esconde en un viejo granero decenas de zombis y una gran horda reduce el lugar a llamas (segunda); el oasis que representa Woodbury termina siendo un símbolo de crueldad (tercera); la construcción de una nueva sociedad en La Prisión no soporta el ataque de un grupo liderado por un hombre loco (tercera y cuarta); y Terminus pasa de la promesa de un santuario a una trampa mortal de caníbales (cuarta y quinta).
} 
momentos de distensión terminen en una sangría ${ }^{23}$. Esta presión lleva incluso a colocar en la trama ciertos temas tabú como son el suicidio, la eutanasia a o el aborto ${ }^{24}$.

De hecho, el culmen de este entorno opresivo se da con el descubrimiento de que todos los humanos son portadores del virus, lo que los convierte en futuros caminantes sea cual sea el motivo de su muerte (213 Beside the Dying Sides). Una situación que termina por minar la moral de los supervivientes y que lleva a situaciones tan estremecedoras como que una Lori embarazada se plantee qué puede ocurrirle si el feto no sale adelante (301 Seed). Cabe destacar que, a lo largo de la cuarta temporada se abre una brecha de esperanza al

${ }^{23}$ Así, una cena casi familiar es golpeada por una horda en el campamento (104 Vatos); tras descubrir el aparente refugio ideal con en una de las pocas instituciones en pie tienen que huir su autodestrucción (106 TS-19); el todavía pequeño Carl Grimes (Chandler Riggs) acaricia un ciervo cuando es disparado (201 What Lies Ahead); Hershel se acostumbra a su prótesis en la pierna cuando otro grupo de zombis ataca la prisión (305 Say the Word); Carol Pelieter (Melissa McBride) bromea junto a un compañero cuando este recibe un disparo en la cabeza (311 I Ain't a Judas); Rick y compañía consiguen una vida relativamente tranquila asentados en La Prisión cuando uno de los más jóvenes muere de una enfermedad gravemente contagiosa (401 30 Days Without An Accident); cuando Tyresse (Chad Coleman) y Carol encuentran un buen refugio con agua y caza, la pequeña Lizzie Samuels (Brighton Sharbino) decide acabar con la vida de su hermana intentando demostrar su teoría sobre una segunda vida zombi (414 The Grove). Una tendencia que continúa en la quinta temporada en la que ya podemos ver una feliz cena con brindis incluido en la Iglesia para que, poco después, Bob Stookey (Lawrence Gilliard Jr.) sea secuestrado por el grupo de caníbales que devoran impasibles una de sus piernas (502 Strangers).

${ }^{24}$ Rick se plantea el suicidio en un momento de máxima tensión (101 Days Gone Bye), mientras que Andrea (Laurie Holden) (201 What Lies Ahead) y Beth Greene (Emily Kinney) (210 18 Miles Out) se piensan seriamente si quieren seguir viviendo en ese nuevo mundo; Jacqui (Jeryl Prescott Sales), Edwin Jenner (Noah Emmerich) (106 TS-19) y Lilly Chambler (Audrey Marie Anderson) (415 Us) lo llevan a cabo. Una reflexión sobre el valor de la vida en esta sociedad sin salida que llega a su esplendor con dos discusiones entre Lori y Rick sobre si su hijo debe sobrevivir a un disparo y llevar una vida de sufrimiento (203 Save the Last One) o la primera decisión de abortar cuando se entera de que está embarazada (206 Secrets). 
incorporar la figura de Eugene Porter (Josh McDermitt), un científico que parece conocer la cura terminando en una falsa esperanza.

La segunda categoría ligada a la otredad también es central en esta producción debido a la forma de construir la unidad del grupo principal en base a un oponente incierto. De esta forma, la primera representación antagónica será Nosotros, supervivientes contra Ellos, caminantes. La amenaza zombi funciona como elemento aglutinador durante la primera temporada en una comunidad de desconocidos que sufren continuas tensiones internas. Pero este villano no tarda en ser desplazado por los propios humanos en una dicotomía Nosotros, humanos buenos contra Ellos, humanos malvados. Y es que la vuelta a ese estado de natural que supone el nuevo mundo postapocalíptico permite representar esa versión hobbesiana del ser humano malo por naturaleza.

De hecho, ya en la segunda temporada se introduce la primera gran confrontación que lleva a Rick y los suyos a defenderse de un violento grupo que busca asesinar, robar y violar. El choque termina con la victoria de los protagonistas pero también con un improvisado rehén (208 Nebraska, 209 Triggerfinger): un chico joven que va a levantar el más profundo recelo de los supervivientes y que va a llevar a la práctica de tortura (210 18 Miles Out) e incluso de pensar en aplicarle la pena capital. Sólo Dale Hovath (Jeffrey DeMunn), intenta convencer a los suyos sobre la importancia de mantener los derechos civiles sin éxito (211 Judge, Jury, Executioner). Una nueva forma de exaltar la seguridad frente a derechos y libertades y justificando cualquier tipo de acto en pro de la supervivencia.

Pero esta experiencia no va a ser un hecho aislado. La tercera y la cuarta temporada gira en torno a un maniqueo Nosotros, los buenos que sólo intentamos sobrevivir en La Prisión, contra Ellos, los malvados de Woodbury que están dispuestos a cualquier cosa por su tenebroso oasis. Una confrontación que acaba en una guerra liderada por dos erráticos líderes ${ }^{25}$ y que deja la amenaza zombi en un segundo

${ }^{25}$ Representada incluso por una visible arenga en la que un Rick que había actuado de forma totalitaria vuelve a su gente: "This is life and death. How you live, how you die, it isn't up to me. I'm not your Governor. We choose to go. We choose to stay. We stick together. We vote" (314 Prey) mientras que el 
plano. Tras la gran batalla, el grupo se divide pero el enemigo sigue siendo la naturaleza humana. Algo que queda claro de camino a Terminus: "Sanctuary for all. Community for all. Those who arrive, survive", donde se van a encontrar con un hostil recibimiento de un grupo de caníbales. Un final de temporada que deja a Rick con un sólido liderazgo que promete revancha con su amenazante: "They're screwing with the wrong people". Un claro proceso de endurecimiento del líder y del resto del grupo ante las asertivas humanas.

A lo largo de este análisis ya se ha hecho referencia en repetidas ocasiones al contenido violento de la serie que, por un lado, es casi una exigencia del género. $\mathrm{Y}$ es que ya el hecho de representar un mundo apocalíptico lleva a la aparición constante de cadáveres, sangre y vísceras. Algo similar ocurre con la supervivencia ligada a la amenaza zombi, que lleva a mostrar infinidad de armas tanto blancas -cuchillos, katana, machetes,...-, como de fuego - revólveres, pistolas, escopetas, rifles, carabinas, fusiles, subfusiles... -, u otros tipos -ballesta, granada...- así como algunas improvisadas -bate de beisbol, destornilladores, guadaña, hacha, horca, martillo,... -. También cabe destacar que si bien en un principio las escenas más violentas recaen en los caminantes, poco a poco se va trasladando también a los humanos que, de forma explícita o implícita, asesinan, pelean, torturan, violan...

Señalar también que la violencia que surge del grupo principal siempre es justificada debido a que es entendida como una herramienta para la supervivencia ${ }^{26}$. En cambio, los antagónicos

llamado Gobernador busca la confrontación desde su papel de líder: "They're no different from the biters. They're not gonna stop until they kill us all, taken everything we've worked so hard for. We're gonna end this once and for all" (316 Welcome to the Tombs).

${ }^{26}$ Además de justificar las torturas o los asesinatos, cabe señalar un personaje emblemático a este respecto: Carol. Una mujer que pasa de estar dominada por su marido maltratador, a una persona capaz de valerse por sí misma y que fuerza cualquier límite tras perder a toda su hija. De hecho, asesina a dos miembros del grupo gravemente enfermos con una contagiosa afección para evitar males mayores, algo que lleva a que Rick a expulsarla de la comunidad (402 Infected, 403 Isolation, 404 Indifference). La historia hace que vuelva a reunirse con el grupo y que tenga que presenciar como una desequilibrada 
suelen estar más relacionados con un uso de la misma basada en la arbitrariedad, la crueldad o incluso el morbo. Destacar también que la violencia va en aumento a lo largo de las temporadas, a medida que los personajes también se van endureciendo. Mención especial a la quinta y última temporada en la que los creadores de la serie dan un paso más al plantear a un grupo de personas engullendo carne humana.

\subsubsection{Dimensión II: El patriarca protector}

Tras el apocalipsis zombi, el Estado desaparece. Los hasta entonces ciudadanos se organizan en pequeños grupos que se construyen en torno a la figura de un líder natural que se encarga de la toma de decisiones. Un liderazgo plenamente masculino -Shane Walsh (Jon Bernthal), Rick, Hershel, Philip Blake, más conocido como El Gobernador (David Morrissey) o Gareth (Andrew J. West) ${ }^{27}$ - que encaja en el citado perfil del estereotipado sujeto político androcéntrico. Aunque sus caracteres difieren, todos ellos van a ser hombres fuertes con tintes autoritarios y paternalistas, basando sus decisiones en la obsesión por la seguridad de los suyos, algo que justifica cualquier tipo de acto -desde abandonar a personas, a torturar, asesinar...-.

Aún así, puede decirse que, a lo largo de las cinco temporadas de The Walking Dead, el espectador recorre junto a Rick el camino de un líder. Como explica José Francisco Pérez Rufí, en un principio se presenta como un protagonista de una película del oeste donde el héroe es el que marca la ley con su comportamiento: "Si en el western las leyes dEl Mundo civilizado no se cumplían por la lejanía de la propia civilización, en este caso es la ausencia de civilización y

Lizzie asesina a su hermana pequeña por su obsesión de una nueva vida zombi. Pese al cariño que le profesa, Carol no duda en pegarle un tiro a la pequeña (414 The Grove). Su carácter maquiavélico se suma a su capacidad de sacrificio por el grupo que hará que Rick la vuelva a aceptar en el grupo (501 No Sanctuary).

${ }^{27}$ Señalar que, durante la última temporada, aparece una mujer que lidera de forma absolutamente dictatorial una pequeña comuna de supervivientes secuestrados: la oficial Dawn Lerner (Christine Woods) pero no se tienen más datos que los proporcionados por el único capítulo en el que aparece emitido hasta la fecha de envío de este artículo (504 Slabtown). 
aparentemente de sociedad la que lleva al héroe a dictar su ley" (Vargas-Iglesias, 2014: 264).

$\mathrm{Y}$ es que durante las dos primeras temporadas va a plantearse como natural la lucha de poder entre Shane y Rick. Una lucha entre dos machos alfa por una forma de entender el liderato -más totalitario el primero- pero también por el control de Lori -amante del primero y esposa del segundo-. Una pugna fratricida que termina cuando la mujer susurra las palabras de la discordia ${ }^{28}$, detonante de la muerte del primero a manos del segundo. Una victoria que, lejos de ampliar la toma de decisiones, termina con Rick proclamando el fin de la democracia con su "This isn't a democracy anymore" (213 Beside the Dying Fire).

Durante la tercera y la cuarta temporada, la lucha se desplaza al exterior del grupo con la confrontación entre dos grandes patriarcas que buscan proteger a sus respectivas comunidades: Rick y El Gobernador. Dos líderes erráticos que controlan firmemente la toma de decisiones. Cabe destacar que, pese a que ambos viven episodios de locura puntuales -el primero ligado a la muerte de su esposa y el segundo a la de su hija, ya zombi- lo cierto es que el grupo sigue respaldando sus decisiones y mostrando pleitesía. Además, contrariamente a Carrie, este estadio es transitorio y no define al personaje.

Rick vuelve a vencer a su antítesis pero, en esta ocasión, con una idea mucho más abierta de la toma de decisiones. Aún así, va a ser justamente su determinación y capacidad para mantener unido al grupo como una gran familia lo que lo encumbre como líder sin ningún tipo de discusión interna. Un momento que se simboliza con la charla en la iglesia en la que, aunque en desacuerdo, todos deciden apoyar la decisión tomada por Rick (503 Four Walls and a Roof).

Esto nos lleva a la segunda categoría donde, lo primero que destaca, es que el perfil de varón como rey de la Seguridad se repite continuamente ligado al male bread winner model, el tradicional

\footnotetext{
${ }^{28}$ You killed the living to protect what's yours? That's right. Shane thinks I'm his. He thinks the baby's his. And he says you can't protect us, that you're gonna get us killed. He's dangerous, Rick, and he won't stop" (209 Trigger finger).
} 
cabeza de familia patriarcal que se encarga del sustento y la protección. Algo a lo que se vuelve en el perfil de los protagonistas tanto Daryl Dixon (Norman Reedus), Glenn Rhee (Steven Yeun) o Abraham Ford (Michael Cudlitz)- y que queda reflejado en sus aptitudes ligadas a los roles productivos o de protección, tanto en torno a lo profesional - cazador, ejército, policía, veterinario- como a sus habilidades -uso de armas, mecánica, táctica, rastreo-. Todo ello hace que, especialmente al inicio de la serie, sean ellos los que se ocupen de la defensa, la seguridad o los trabajos más físicos, que también son aquellos más ligados a la esfera pública -y aquellos con más reconocimiento-. De esta forma, sus actitudes se relacionan con amistad, competitividad, fraternidad, fuerza, independencia, iniciativa, inteligencia, liderazgo, seguridad, supervivencia o violencia. Así como son habitualmente perfilados con carácter agresivo, cruel y exacerbando su virilidad y destacando, en ocasiones, por una actitud condescendiente hacia las mujeres, claramente paternalista.

Por el contrario, el pasado profesional de las protagonistas es desconocido o está ligado al hogar o a la maternidad, o no es relevante en este nuevo mundo -como Andrea (Laurie Holden), abogada-. Lo mismo ocurre con las habilidades que terminan por desarrollar la división sexual del trabajo, enlazada a la idea de Carole Pateman de que "la provisión de «trabajo doméstico» es parte del significado patriarcal de la feminidad, de lo que es ser mujer" (1995: 175). Un hecho magnificado porque, durante las primeras temporadas, ninguna mujer sea capaz de hacer uso de las armas.

De forma contraria, las mujeres se ligan a la esfera de lo privado, un espacio que Alicia Miyares entiende como "las relaciones que no determinan en absoluto la organización del Estado; la esfera privada está caracterizada por el lenguaje emocional, implica el género de relaciones mediadas por los afectos y los sentimientos negativos o positivos" (2003: 61). Es decir, se definen a través del amor romántico o la sexualidad, los cuidados -asistencia a enfermos o niños y niñas-, la dependencia -necesidad de protección o subsistencia-, emotividad -mostrando sus sentimientos-, infravaloración -actos y habilidades menos estimados-, irracionalidad -impulsividad, sin táctica-, sumisión -acatando órdenes-, maternidad, pacifismo buscando la solución no violenta al conflicto-, o directamente a las 
tareas del hogar. Ejercen el papel, en definitiva, de continuidad con El Mundo anterior dotando de ciertas dosis de normalidad a la comunidad $^{29}$. Una diferencia entre protectores y protegidas que lleva a los hombres a tener una actitud en ocasiones condescendiente, paternalista e incluso posesiva. Todo ligado a que se mantienen alejadas de la acción y el liderazgo ya que, como explica David Caldevilla, las series de televisión estadounidense tienden a representar la prototípica familia nuclear donde la iniciativa queda relegada a los papeles masculinos de tal forma que "o bien evitan a las mujeres con iniciativa o bien la acentúan de sobremanera, cargando su actitud con connotaciones negativas" (2010:76).

Justamente en este segundo ámbito se encuentra Andrea, el primer papel femenino en reivindicar su presencia en la acción, aprendiendo a manejar armas. Cabe destacar que el aumento de su incursión el espacio público viene ligada al continuo fracaso o la torpeza, así como a cierta exaltación de los roles femeninos -emotividad, hipersexualización, amor romántico-. Eso hace que no sea capaz de transgredir la barrera sexo género y que quede alejada de la fraternidad o el respeto que gozan sus compañeros, algo vinculado al hecho de haberse inmiscuido en un espacio que no le corresponde y que Celia Amorós (1985) achaca a las lógicas compartidas de capitalismo y patriarcado.

Pese a todo, Andrea abre la puerta a otro modelo femenino en la serie. A partir de aquí, se ve una clara evolución hacia la acción y la toma de decisiones -especialmente Maggie, Carol o Beth a lo largo de los últimos capítulos-, así como la aparición de figuras fuertes. En

${ }^{29}$ Un hecho que se visibiliza entre la siguiente discusión entre Lori y Andrea (210 18 Miles out): Andrea: I contribute. I help keep this place safe. / Lori: The men can handle this on their own. They don't need your help. [...] There's plenty of work to go around. / A: Are you serious? Everything falls apart, you're in my face over skipping laundry? / L: Puts a burden on the rest of us, on me and Carol, and Patricia and Maggie. Cooking, cleaning and caring for Beth. And you... you don't care about anyone but yourself. You sit up on that $\mathrm{RV}$, working on your tan with a shotgun in your lap. / A: No, I am on watch against walkers. That is what matters, not fresh mint leaves in the lemonade. / L: And we are providing stability. We are trying to create a life worth living. / A: Are you kidding me? [...] Playing house, acting like the queen bee, laying down rules for everybody but yourself... 
este sentido, destacar a Michonne (Danai Gurira): una mujer que se distancia de los estereotipos prototipos con valores asociados como amistad, fuerza, independencia, iniciativa, inteligencia, liderazgo, seguridad, supervivencia o violencia. Si bien a lo largo de la cuarta temporada se va introduciendo al personaje al mundo de las emociones, la maternidad y los cuidados -especialmente en torno a Carl-. Cabe destacar también que Andrea y Michonne protagonizan la primera alianza femenina- entendida como relación horizontal de cooperación, complicidad e independencia entre mujeres-, algo poco habitual hasta el momento dejando la fraternidad relegada únicamente a los hombres. A partir de aquí, aparecen otros personajes femeninos que rompen en parte con los moldes establecidos como Sasha (Sonequa Martin-Green) o Rosita Espinosa (Christian Serratos) aunque ambas se ligan con el amor -de hermano y de pareja-, el sexo y con la hipersexualidad -especialmente la segunda-.

\section{Conclusiones}

A lo largo del análisis de la primera dimensión se puede ver cómo el miedo a un ataque de un enemigo incierto es el motor que mueve ambas ficciones. Homeland nos lleva a un escenario post $11 \mathrm{~S}$ donde el terrorismo árabe se convierte en la amenaza central. Mientras que El Mundo postapocalíptico de The $W$ alking Dead nos traslada a un estadio de la naturaleza donde el ser humano asediado por la muerte saca lo peor de sí. De forma más o menos metafórica ambas series nos hablan de la supremacía de la Seguridad sobre unos derechos y libertades que quedan en segundo plano cuando se habla de supervivencia.

Y esa amenaza viene de la mano de un Otro que actúa como antítesis maniquea de Nuestro grupo. Sea este los EEUU o una pequeña comunidad de supervivientes. $\mathrm{Y}$ para poder detener a ese enemigo que amenaza con destruir nuestra sociedad queda justificado cualquier tipo de acto. Otra vez la Seguridad gana.

Y ese fin justifica los medios entiende como fin la Seguridad y como medios cualquier aspecto que sea necesario, incluida la violencia. Y aunque las dosis son absolutamente diferentes en ambas, aséptica en Homeland y grotesca en The Walking Dead, lo cierto es que la justificación de su uso es la misma. Amenazas, asesinatos, chantajes, 
manipulaciones, torturas... cualquier acto por proteger la integridad del grupo.

El discurso del miedo también impacta de lleno en la sociedad y, con ello, en la representación de la misma. El liderazgo del grupo principal se mezcla con el heroísmo, aunque este sea errático e imperfecto. Una agente de la CIA obsesionada con su trabajo y con un desorden bipolar, un ayudante de sheriff desquiciado tras la muerte de su esposa. Todo vale mientras que el que tome las decisiones sea capaz de asegurar la supervivencia del grupo que lidera. Aunque un perfil es más usual que el otro.

Si algo muestran ambos dramas es la diferencia a la hora de crear los personajes. Mientras los hombres se ligan con la acción y la toma de decisiones, ocupando de forma natural el espacio público. Las mujeres quedan relegadas a un mundo más pasivo y emocional, siempre en el campo de lo privado. Y, siempre que traspasan esta línea, se muestra claramente que están en un terreno que no es el suyo. Y, a pesar de que Carrie, Andrea, Michonne o Maggie son personajes aparentemente fuertes y activos, siguen encadenadas a ámbito ligado al amor, los cuidados o la irracionalidad y fuertemente objetivizadas sexualmente ante la mirada masculina. Una recreación de la sociedad norteamericana que decidió apostar por una fachada de virilidad normativa frente a esa amenaza invisible levantada tras aquel 11 de Septiembre.

\section{Referencias bibliográficas}

Aguado Peláez, Delicia (2013): "El impacto del 11S en la Cultura Popular Norteamericana. Análisis de la serie de televisión Homeland (Showtime, 2011-)", en Viento Sur, 129, Septiembre, recuperado el 18 de julio de 2014, de http://vientosur.info/IMG/pdf/VS129_D_Aguado_Analisis_serie_Homeland .pdf

Aguado Peláez, Delicia (2014): "Imaginario postapocalíptico en las series de televisión norteamericanas tras el 11S: Análisis de The Walking Dead (AMC, 2010-)", en Fernández-Astobiza, Itxaso (ed.). Espacios de Comunicación. Actas del IV Congreso Internacional de la Asociación Española de Investigación de la Comunicación, AE-IC. Bilbao, páginas 1091-1100, recuperado el 18 de julio de 2014, de 
http://www.aeic2014bilbao.org/download/aeic2014bilbao_comunicaciones.pd $\mathrm{f}$

Aguado Peláez, Delicia (2014): " Cuando el patriarcado sobrevive al apocalipsis: Análisis de The Walking Dead (AMC, 2010-)", en Feminismo/s, n²3, aprobado y pendiente de publicar.

Antón, Laura (2014): "Un drama pasional de la mujer investigadora. Un arquetipo femenino de la crisis", en Revista Científica de Cine y Fotografía, 8 , páginas 57 a 82, recuperado el 5 de noviembre de 2014, de http://www.revistafotocinema.com/index.php?journal=fotocinema\&page $=$ arti cle\& op=view\&path $]=230$

Amorós, Celia (1985): Hacia una crítica de la razón patriarcal. Madrid: Anthropos.

Beck, Ulrich (2001): "El Mundo después del 11-S", en El País (edición digital), 19 de octubre, recuperado el 11 de noviembre de 2014, de http://elpais.com/diario/2001/10/19/opinion/1003442407_850215.html

Beck, Ulrich (2002): La sociedad del riesgo global. Madrid: Siglo XXI.

Beck, Ulrich (2008): La sociedad del riesgo mundial. En búsqueda de la seguridad perdida. Barcelona: Paidós.

Cascajosa, Concepción (2003): “A través del espejo: El Mundo después del 11- S en '24'”, en Revista Latina de Comunicación Social, 56, recuperado el 4 de marzo de 2013, de

http://www.ull.es/publicaciones/latina/20035632cascajosa.htm

Cascajosa, Concepción (2005): Prime Time, Las mejores series de TV americanas, de CSI a Los Soprano. Madrid: Calamar Ediciones.

Cascajosa, Concepción (2007): La Caja Lista: Televisión norteamericana de culto. Barcelona: Laertes.

Caldevilla, David (2010): “Estereotipos femeninos en series de televisión”, en Chasqui, 111, páginas73 a 78.

Crisóstomo Gálvez, Raquel (2013): “El enemigo que ya no está en las puertas. $\mathrm{El}$ nuevo enemigo doméstico en la serialidad estadounidense contemporánea: el caso de Dexter y Homeland", en Revista Comunicación y Hombre, 9, páginas 3 a 11, recuperado el 6 de noviembre de 2014, de http://www.comunicacionyhombre.com/articulo.php?articulo=134

Cuadrado Alvarado, Alfonso (2013): "Ulises y el héroe terrorista: Mito y modernidad en la serie "Homeland "'", en Área Abierta, 13, 1, páginas 27 a 42, 
recuperado el 3 de noviembre de 2014, de

http://dx.doi.org/10.5209/rev_ARAB.2013.v34.n1.41589

Damean, Diana (2006): "Media and gender: Constructing feminine identities in a postmodern culture", en Journal for the Study of Religions and Ideologies, 5, 14, recuperado el 9 de noviembre de 2014, de http://jsri.ro/ojs/index.php/jsri/article/view/360

De Felipe, Fernando y Gómez, Ivan (2011): Ficciones colaterales. Las huellas del 11-S en las series 'made in USA'. Barcelona: UOCpress.

Dixon, Winston (2004): Film and Television after 9/11. Carbonade: Southern Illinois University Press.

Frezza, Gino (2009). "Guerras y postguerras. La visión política del futuro en la ciencia ficción de los cómics, películas y series contemporáneas", en Formats. Revista de Comunicació Audiovisual, 5, recuperado el 10 de diciembre de 2012, de http://www.upf.edu/materials/depeca/formats/pdf_/art_dos_esp1.pdf

Faludi, Susan (2009). La pesadilla terrorista. Miedo y fantasía en Estados Unidos después del 11-S. Barcelona: Anagrama.

Fernández, Marta y Menéndez, María Isabel (2011): "Lo que el ojo no ve: Renovación vs conservadurismo en la ficción audiovisual posterior al 11S", en Actas III Congreso Internacional Latina de Comunicación, recuperado el 4 de marzo de 2013, de http://www.revistalatinacs.org/11SLCS/actas_2011_IIICILCS/024.pdf

Grandío (2009). María del Mar y MURUZÁBAL, Amaya (2009). "La representación de la guerra en la ficción televisiva norteamericana", en Mediaciones Sociales, 5, páginas 63 a 83, recuperado el 4 de marzo de 2013, de http://revistas.ucm.es/index.php/MESO/article/view/MESO0909220063A/2 1182

Huerta, Miguel Ángel (2006): Celuloide en llamas. El cine estadounidense tras el 11-S. Madrid: Notorious

Mateos Sillero, Sara (2013): "Construcción de la feminidad normativa y sujeto político", en Investigaciones feministas, 4, páginas 297 a 321, recuperado el 8 de noviembre de 2014, de http://revistas.ucm.es/index.php/INFE/article/view/43894/41492

Miyares, Alicia (2003): Democracia feminista. Madrid: Feminismos.

Murray, Shelby C. (2014): "The Deceptions of Powerful Female Roles: A Feminist Critique of Homeland", en tesis doctorial de la California Polytechnic 
State University, San Luis Obispo, recuperado el 9 de noviembre de 2014, de http://digitalcommons.calpoly.edu/cgi/viewcontent.cgi?article=1158\&context $=\mathrm{co}$ mssp

Pateman, Carol (1995): El contrato sexual. Barcelona: Anthropos.

Piñuel, José Luis (2002): "Epistemología, metodología y técnicas del análisis de contenido", en Estudios de sociolingüística: Linguas, sociedades e culturas, 3 , $\mathrm{n}^{\circ} 1$, páginas 1 a 42 .

Puleo, Alicia (2005): “El patriarcado ¿una organización superada?”, en Temas para el debate, 133 , páginas 39 a 42.

Puleo, Alicia (2000): Filosofía, género y pensamiento crítico. Valladolid: Universidad de Valladolid.

Ruiz Olabuénaga, Jośe Ignacio (2012). Metodología de la investigación cualitativa. Bilbao: Universidad de Deusto.

Sanchez-Escalonilla, Antonio (2009): "Hollywood y el arquetipo del atrincherado. Clave dramática y discurso político del 11-S", en Revista Latina de Comunicación Social, 64, páginas 926 a 937, recuperado el 10 de diciembre de 2012, de http://www.revistalatinacs.org/09/art/871_URJC/72_110_Antonio_Sanchez_ Esc alonilla.html

Vargas-Iglesias, Juan J. (coord.) (2014): Los héroes están muertos. Heroísmo y villanía en la televisión en el nuevo milenio. Palma de Mallorca: Dolmen Editorial.

Thompson, Robert (1996): From Hill Street Blues to Er. Television's Second Golden Age. New York: Syracuse University Press.

Tous, Anna (2010). La era del drama en televisión. Perdidos, CSI: Las Vegas, El ala oeste de la Casa Blanca, Mujeres desesperadas y House. Barcelona: UOC Press.

* Este texto forma parte del estudio que estoy realizando para mi tesis doctoral titulada Post 11S en la Ficción Televisiva: Análisis de la serie Perdidos (Lost, Abc, 2004-2010); con ayuda del Programa de Formación de investigadores del DEUI del Gobierno Vasco. 


\title{
La "pobreza energética" en el relato periodístico sobre la crisis en España
}

\author{
$\mathrm{M}^{\mathrm{a}}$ José Pou Amérigo, Universidad Cardenal Herrera-CEU, \\ mpou@uch.ceu.es \\ Estrella Israel Garzón, Universidad Cardenal Herrera-CEU, \\ estrella.univ@gmail.com
}

Resumen: A pesar de la realidad creada por la crisis, en nuestro país, el debate público acerca de la pobreza energética es muy reciente. En opinión de Sergio Tirado, coordinador del estudio "Pobreza energética en España", ello se debe a que los precios de la energía no han sido motivo de discusión pública hasta hace relativamente poco. Las primeras referencias a la "pobreza energética" referidas a la realidad española no aparecen en la prensa hasta 2010 pues, con anterioridad, el concepto se refería a países en vías de desarrollo. Sin embargo, es en 2013 cuando se incrementa su presencia a partir del debate político sobre las tarifas eléctricas y las fuentes de energía.

En este trabajo, realizado en el marco del Plan Nacional de I+D+I (referencia CSO2012-38363) se analiza la presencia del concepto "pobreza energética" en la prensa española, se estudia con qué causa se vincula y qué voces hablan del tema con objeto de explicar desde qué enfoque se presenta al lector esta realidad. Para el análisis, se han seleccionado los textos informativos o interpretativos de los diarios El País, El Mundo, $A b c$ en el año 2013 y se ha estudiado qué enfoque (framing) predomina: social (pone el acento en las consecuencias 
humanas y familiares de la pobreza energética); económico (pone el acento en las causas, la crisis, el consumo, la eficiencia y la sostenibilidad) y político (pone el acento en el conflicto entre los distintos actores implicados, el empoderamiento de los ciudadanos en materia energética y la política energética desarrollada por los gobiernos).

Palabras clave: Pobreza energética, política energética, framing, análisis del discurso, encuadres noticiosos, periodismo social.

\section{Introducción}

T A ASOCIACIÓN de Ciencias Ambientales define "pobreza Lenergética" como "la incapacidad de un hogar de satisfacer una cantidad mínima de servicios de la energía para sus necesidades básicas, como mantener la vivienda en unas condiciones de climatización adecuadas para la salud".

Se trata de un concepto presente en otros países europeos que, sin embargo, en España ha comenzado a utilizarse muy recientemente. La razón, según recoge Sergio Tirado en "Pobreza energética en España", es el interés actual por los precios de la energía, en especial, las tarifas eléctricas. Prueba de ello es que 2012 apenas registra movimiento social al respecto, salvo del Día de Lucha contra la Pobreza Energética que establece el Reino Unido el 10 de febrero. No obstante, en la prensa se recoge información sobre las dos subidas de precio de la luz durante ese año. No hay respuesta social pero sí se alza la voz de las organizaciones de consumidores. 2012 y 2013 son dos años de constantes informaciones sobre las tarifas de la luz. También hay referencias al gas o a otros gastos básicos como el transporte pero la que centra la atención es la energía eléctrica. Noticias sobre subidas de tarifas, ajustes, subastas, déficit tarifario... son frecuentes, sobre todo, en el año 2013.

\section{Objetivos y metodología}

El objetivo de esta comunicación es identificar el tratamiento informativo de la "pobreza energética" en la prensa española, su 
conceptualización y divulgación y la construcción del relato en el marco de la crisis económica.

Para ello, se aplicará la perspectiva del framing (Vicente Mariño, M. y López Rabadán, P., 2009; Mercado, MT, Sánchez, S., y Álvarez, A., 2014 y Mercado, MT, Herranz, J.M., y Álvarez, 2014) con objeto de saber qué enfoque predomina: social (pone el acento en las consecuencias humanas y familiares de la pobreza energética); económico (pone el acento en las causas, la crisis, el consumo, la eficiencia y la sostenibilidad) y político (pone el acento en el conflicto entre los distintos actores implicados, el empoderamiento de los ciudadanos en materia energética y la política energética desarrollada por los gobiernos), así como las voces que hablan del tema (ONG, políticos, expertos, protagonistas).

Para el análisis, se han seleccionado los textos informativos o interpretativos de los diarios El País, El Mundo y Abc en el año 2013, a partir de la muestra obtenida de la base de datos MyNews, utilizando para la búsqueda la expresión "pobreza energética". Se han elegido esos periódicos por su difusión, su ámbito territorial y su presencia en todo el periodo 2008-2013, desde el inicio de la crisis hasta el año cuantitativamente más relevante en referencias a la "pobreza energética". El análisis cualitativo se ha centrado en 2013 por esa razón.

La hipótesis de partida es que en España preocupa la pobreza energética a partir de la subida de las tarifas de la electricidad y con motivo del conflicto entre las autoridades y las empresas del sector. Para saberlo, interesa analizar con qué hechos vincula cada periódico las noticias en las que habla de esa realidad, si son noticias económicas o enfrentamientos políticos.

Asimismo, el interés por la "pobreza energética" puede suponer un ejemplo de práctica periodística movilizadora si las fuentes oficiales pasan a un segundo plano, el de la estadística, y aumenta el discurso social vinculado a los pobres energéticos tanto en sus vivencias, su cotidianeidad, -especialmente en reportajes periodísticos- como en el apoyo y la movilización social desde organizaciones como Cruz Roja, Caritas o Plataformas por un nuevo modelo energético. Para ello analizaremos las fuentes y los protagonistas de los textos. 
La ficha de análisis contiene los siguientes campos:

Datos de identificación: Fecha, diario, titular, web, sección y género.

Interesa saber en qué sección se ubica la noticia porque de ello dependerá el enfoque que se le dé, ya sea social, político o económico. Del mismo modo, la elección de género indicará la importancia y continuidad que el medio da al tema.

Datos sobre autores, fuentes y voces: Autoría, firma, fuentes, actor principal. La autoría y la firma ayudan a distinguir si se trata de un periodista de la redacción, un corresponsal o una agencia y de quién se trata, especialista o no. Las fuentes indican si el medio ha consultado fuentes oficiales $\mathrm{e}$ institucionales $\mathrm{o}$ bien fuentes secundarias y alternativas. Por último, la presencia del actor principal nos ayuda a determinar también el enfoque, ya sea por predominio de voces políticas, empresariales o ciudadanas.

Datos sobre la presentación del problema y su origen: definición, caracterización y causas. Con estos datos podemos contextualizar mejor la visión sobre el tema que tiene el periódico. Hemos diferenciado tres enfoques: social (pone el acento en las consecuencias humanas y familiares de la pobreza energética); económico (pone el acento en las causas, la crisis, el consumo, la eficiencia y la sostenibilidad) y político (pone el acento en el conflicto entre los distintos actores implicados, el empoderamiento de los ciudadanos en materia energética y la política energética desarrollada por los gobiernos).

\section{Resultados}

Los textos analizados son 34: El País, 16; Abc, 10; El Mundo: 8. De todos ellos, solo seis corresponden a reportajes. Todos los demás son noticias. En $A b c$ solo tres son textos de agencia; en El Mundo, cuatro y en El País, siete. Hemos de tener en cuenta que ese dato varía cuando la edición es digital o impresa puesto que en la digital, la inmediatez hace que se publiquen informaciones de agencia que, después, no tienen su correlato en el periódico impreso.

Las fuentes y protagonistas en $A b c$ son entidades sociales, plataformas y ONG así como políticos. Entre las entidades sociales: 
Cruz Roja, José Luis López, Asociación Ciencias Ambientales (2); Vicente Barcía, Plataforma por un nuevo modelo energético; Rubén Sánchez, Facua; Francisco Valverde, presidente de la Asociación Nacional de Ahorro y Eficiencia Energética (ANAE). Entre los políticos: la vicepresidenta del gobierno escocés; Elena Valenciano y el Ministro Soria (4).

En El Mundo también encontramos entidades sociales y políticos: Cruz Roja; Rafael Herrero, presidente de la Asociación de Empresas de Servicios Energéticos (Anese); Asociación de Empresas de Eficiencia Energética (A3E), Manuel Sayagués; Javier García Breva, presidente de la Coalición Empresarial Nuevo Modelo de Negocio Energético (N2E); la responsable del programa Sin Hogar y Vivienda de Caritas Diocesana Barcelona, Teresa Bermúdez. Entre los políticos, el ministro Soria; el líder de ICV, Joan Herrera; CiU en la Junta de Portavoces de la Cámara Baja, Pere Macías; y la portavoz UPyD, Rosa Dízz.

En El País, además de numerosas fuentes sociales y políticos, hay un tercer grupo que es el de los afectados, para contar historias de vida y casos que hagan más comprensible la realidad de la "pobreza energética". Son Verónica Giráldez, José Manuel Goig y Juan Presa. Entre las fuentes sociales, además de incluir ONG y plataformas cívicas, hay fuentes de las empresas afectadas: Luis Jiménez Herrero, director OSE, el Observatorio de la Sostenibilidad en España; José Javier Sánchez Espinosa, subdirector de Cruz Roja; OMS; Sergio Tirado, vicepresidente de la Asociación de Ciencias Ambientales, OCU; Kandeh K. Yumkella, director general de la Organización de las Naciones Unidas para el Desarrollo Industrial (ONUDI); secretario general de la ONU, Ban Ki-moon; viceministro industria chino; Ramón Silva, responsable de innovación y desarrollo de servicios energéticos de Gas Natural Fenosa; Cecilia Foronda, directora de cambio climático, agua y energía de la Fundación Ecología y Desarrollo (Ecodes); Alberto Coloma, gerente de la fundación La Casa que ahorra; organizadores de la campaña "Bájate la potencia"; Marta García, responsable de pobreza energética de la asociación catalana Ecoserveis; José Luis López, miembro de ACA; Manuel Silva, asesor de la Consejería andaluza de Administración Local; Joana Mundó, de Ecoserveis; Rubén Sánchez, Facua; Luis 
Babiano, gerente de la Asociación Española de Operadores Públicos de Abastecimiento y Saneamiento; Luis Jiménez, director del Observatorio de la Sostenibilidad de España; Comité Económico y Social Europeo (CESE); Iberdrola y Endesa; INE; Gas Natural Fenosa; Rubén Sánchez, Facua. Por último, están presentes políticos los políticos: Ministro Soria, 2; Laia Ortiz, IU-iCV-CHA, 2; Mario Flores, PP; Miguel Sebastián, PSOE; Soraya Sáez de Santamaría, vicepresidenta; secretario de Ordenación del Territorio y Sostenibilidad del PSOE, Hugo Morán; Pere Macías, de CiU; Joan Tardá de ERC; portavoz de Equo, Juan López de Uralde; Cayo Lara, coordinador IU.

La diferencia entre ellos es que las fuentes no políticas forman parte de los reportajes mientras que las demás aparecen en las noticias, numéricamente más abundantes. Eso significa que cuando analizan el tema a fondo consultan fuentes no gubernamentales pero en el día a día la pobreza energética no es noticia excepto para la guerra entre partidos o en el conflicto entre las empresas y el gobierno. El único que incluye afectados en el relato informativo es El País.

El enfoque que predomina en los periódicos es el político:

En $A b c$, junto al político (7) predomina el enfoque social (2), mientras que el económico apenas aparece y cuando lo hace está vinculado al consumo (1). En El Mundo, también predomina el político (4) pero el social y el económico aparecen con la misma importancia (2). Por último, en El País el político también sobresale (8) pero cerca tiene el enfoque económico (6) desarrollado sobre todo en lo que se refiere a la eficiencia y la sostenibilidad. En sus textos sociales (2), incluye testimonios de afectados.

Respecto a las causas, para $A b c$, predomina la referencia a la crisis y los precios de la luz, mientras que El Mundo añade los problemas de eficiencia. El País da peso a ambos factores por igual y, además, los pone en relación al contexto europeo e internacional. Cuando trata la guerra política pone el acento sobre la política energética del gobierno. 


\section{Conclusiones}

1. El concepto de "pobreza energética" no empieza a tratarse en España referido a una realidad propia hasta el año 2010 aunque será en 2013 cuando los enfrentamientos políticos, la reforma del sector eléctrico y la política energética del gobierno hacen que la prensa fije su atención en esta nueva realidad.

2. Entre las causas, las que destacan todos los medios son la subida de los precios, especialmente de electricidad, y la crisis, y solo secundariamente se referirán a los problemas de eficiencia energética en los hogares.

3. La "pobreza energética" es un tema en el que los medios buscan fuentes no gubernamentales y plataformas ciudadanas dándoles peso como fuentes principales. Sin embargo, dado que la mayoría de noticias son de tipo político, las fuentes y los protagonistas siguen siendo los representantes de los partidos políticos.

\section{Referencias bibliográficas}

Asociación de Ciencias Ambientales (2014), Estudio de Pobreza Energética. Análisis de tendencias, Madrid.

Ecoserveis (2012), La pobresa energética a Catalunya. Situació actual i propostes d'acció. Dossier 24. Taula d'Entitats del Tercer Sector Social de Catalunya. Dossiers del Tercer Sector, n.23, febrero 2012. http://issuu.com/ecoserveis/docs/la_pobresa_energtica_a_catalunya $/ 1$ ?e $=4822241 / 3793879$, fecha de consulta: 2 de abril de 2014 .

Mercado, MT, Sánchez, S., Àlvarez, A. (2014). "Los científicos como actores y fuentes en el discurso mediático sobre la energía nuclear", en Prisma Social 12, pp. 544-580.

Mercado, MT; Àlvarez, À.; Herranz, JM. (2014). “The fracking debate in the media: The role of citizen platforms as sources of information", en ESSACHESS. Journal for Communication Studies, vol. 7, no. 1(13), pp. 45-62. 
Proyecto Europeo EPEE (2006), Diagnosis de las causas y de las consecuencias de pobreza energética en Bélgica, Francia, Italia, España y Reino Unido.

Tirado, Sergio, "La pobreza energética entra en el debate público en España”, Ambientum.Com, noviembre 2013. Especial Energías renovables y eficiencia, web:

http://www.ambientum.com/revista/2013/noviembre/pobrezaenergetica- debate-publico-espana.asp , fecha de consulta: 10 de abril de 2014.

Vicente-Mariño, Miguel y López Rabadán, Pablo (2009) "Resultados actuales de la investigación sobre framing: sólido avance internacional y arranque de la especialidad en España", ZER, vol. 14, núm. 26.

Este trabajo se enmarca en el proyecto "Análisis del tratamiento informativo de las políticas energéticas en España, procesos de recepción y participación de organizaciones sociales" (Plan Nacional de $\mathrm{I}+\mathrm{D}+\mathrm{I}$, referencia CSO2012-38363). 


\section{La crisis económica en España y la accidentalidad laboral: análisis cuantitativo en la prensa}

Sergio Arce García. Universidad Internacional de La Rioja (UNIR) sergio.arce@unir.net

Resumen: Tras la publicación en 1995 de la Ley 31/1995 de Prevención de Riesgos Laborales, por transposición de la Directiva Europea 89/391/CEE, se introdujo en España un nuevo concepto de prevención sobre los accidentes laborales, proveniente de una directiva con principal enfoque de mentalidad y funcionamiento de los países del norte europeo.

Lo que se esperaba que fuese un medio para disminuir los altos niveles de accidentalidad laboral en España, se tradujo en la realidad en un aumento de los mismos hasta los años 2002-2003, así como en el número de fallecidos en el trabajo. Solo a partir de dicho periodo, tras reformas legales, más medios y concienciación, la siniestralidad comenzó a disminuir. Con el comienzo de la crisis en España, a partir del año 2008, los accidentes laborales disminuyeron drásticamente, principalmente los leves pero no en la misma proporción los graves o muy graves.

En esta comunicación se plantea como objetivo estudiar la construcción de la opinión pública a partir de la representación mediática de la siniestralidad laboral y su prevención a través del análisis de los cuatro medios de comunicación de prensa escrita 
general de mayor tirada en España (El País, El Mundo, Abc y La Vanguardia), determinando de manera cuantitativa los artículos dedicados a la siniestralidad y su prevención en el periodo de los años de crisis económica a partir de 2008, comparándolo con los niveles de atención anterior y con los niveles de accidentalidad existentes.

Palabras clave: Prensa. Accidentes. Prevención de Riesgos Laborales. Comunicación. Crisis.

\section{Justificación y relevancia}

L

A PROTECCIÓN de la salud de los trabajadores es definida por una conferencia en Nueva York en el año 1946, y sigue inalterada, siendo posteriormente firmada a lo largo de los años por multitud de países en todo El Mundo.

En España la protección de la salud del trabajador en el ambiente laboral es un derecho y una obligación recogido en la legislación española en la Ley 31/1995 de Prevención de Riesgos Laborales, tras la transposición de la Directiva Marco 89-391-CEE. Tras un periodo de ascenso de la siniestralidad laboral, a partir del año 2002-2003 comenzó a disminuir, la entrada de una profunda crisis económica y social ha trastocado todos los datos conocidos hasta entonces.

El objetivo de este artículo es analizar el papel de los medios de comunicación, en este caso de los principales medios de prensa escrita, ante los cambios en las relaciones laborales, en concreto con la siniestralidad laboral. Los medios de comunicación pueden ofrecer los contenidos de forma que sensibilicen una cierta miopía ante ciertos temas, ya que el conjunto de lectores busca implicaciones a la vez directas, inmediatas y simultáneas (Kientz, 1976: 106).

Este análisis forma parte de un estudio más amplio que se encuadra en una tesis doctoral in progress, dedicada a esta temática y cuyos objetivos generales están orientados a estudiar la relación entre opinión pública, salud y seguridad en el empleo 


\section{La siniestralidad laboral y la crisis económica en el periodo 2008-2013}

El contexto de la legislación preventiva española proviene de la transposición de la Directiva Marco Comunitaria 89/399/CEE, por lo que la base legislativa de todos los países de la Unión Europea es la misma. Para poder comparar entre distintos países, sectores o periodos temporales, independientemente de su población debe atenderse a los índices estadísticos más usados en El Mundo de la prevención de riesgos laborales. El mejor para realizar estas comparaciones es el denominado índice de frecuencia, que se define como el número de accidentes por cada millón de horas trabajadas, pero como es difícil de plasmar el número de horas trabajadas en grandes poblaciones se utiliza más el denominado índice de incidencia, que es la relación entre número de accidentes por cada porción de trabajadores (Bestratén Belloví y Turmo Sierra, 1982: 3-4). El mayor problema del índice de incidencia es conocer la población ponderada de riesgo, tomándose generalmente como población asalariada la procedente de la encuesta de población activa (EPA) (Mora Plaza, 2005: 8).

\subsection{Evolución de la siniestralidad laboral en el periodo 2008- 2013 y comparación anterior}

Tras unos años de descenso de la siniestralidad laboral, donde las medidas y reformas implantadas desde 1995 y reformas de los primeros años del siglo XXI comenzaron a dar fruto, la llegada de la crisis económica a partir de 2008 ha provocado un cambio en el número y características de los accidentes laborales en España.

Puede comprobarse de esta Figura 1 que el número de accidentes laborales con baja (ausencia del trabajo superior a tres días), tras unos años de elevadas cifras en los que cada año el número de trabajadores en activo era más grande, comienza a descender bruscamente a partir del año 2008. Podría entenderse este descenso en el número de accidentes al disminuir el número de trabajadores, pero los accidentes sin baja se mantienen más o menos constantes a pesar de ese mismo descenso. 
Figura 1: Accidentes con Baja y Sin Baja (sin contar in itinere) 1994-2013. Fuente: Elaboración propia a partir de los Anuarios de Estadística del Ministerio de Trabajo 19942013.

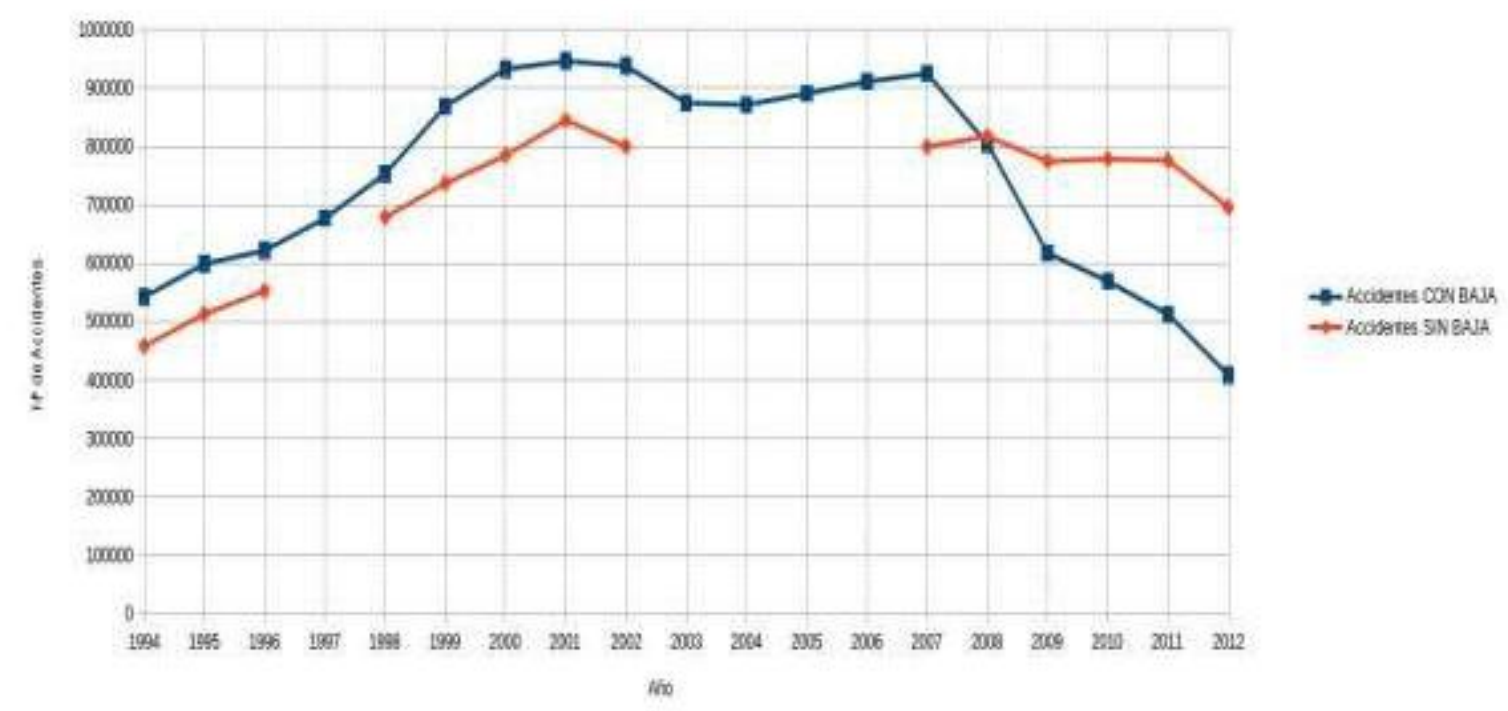

Aunque quedan algunos años sin datos ofertados por el Ministerio de Trabajo de España sobre accidentes laborales sin baja, puede observarse claramente una tendencia alcista desde la entrada de la Ley 31/1995 de Prevención de Riesgos Laborales, hasta un volumen constante de accidentes con baja, que caen a partir de 2007 drásticamente debido a la crisis económica (Sedano et al., 2014: 78).

No ocurre así con los accidentes laborales sin baja, que llevaban una tendencia similar a los que ocasionaban baja, pero siempre en un nivel inferior hasta el año 2008, a partir del cual los accidentes sin baja quedan por encima. Esta tendencia puede explicarse principalmente, entre otros factores, al miedo al despido ante la declaración de accidentes leves o moderados, sobre todo en la pequeña y mediana empresa (Davies, Jones y Núñez, 2009: 178).

En el estudio de Boone, van Ours, Wuellrich y Zweimüller (2011: 770-773) sobre la influencia de la crisis económica en Austria se refleja que la probabilidad de despido en época de bonanza económica es de entre el $20 \%$ y $21 \%$ superior entre aquellos trabajadores que habían sufrido bajas por accidentes leves. Comprobaron igualmente que en el caso de accidentes graves o muy graves el aumento de dicho porcentaje era insignificante. En épocas de crisis siguieron observando los mismos porcentajes de despido, aunque apreciaron un descenso claro de las notificaciones leves y 
moderadas por parte de los trabajadores por miedo a perder su puesto de trabajo, pero no en las graves.

El descenso del número de bajas por accidentes laborales es especialmente marcado entre los trabajadores con contrato temporal frente a los trabajadores con contrato indefinido:

Figura 2: Accidentes con baja laboral en España por tipo de contrato 2000-2012. Fuente: Elaboración propia a partir de los Anuarios de Estadística del Ministerio de Trabajo 19942013.

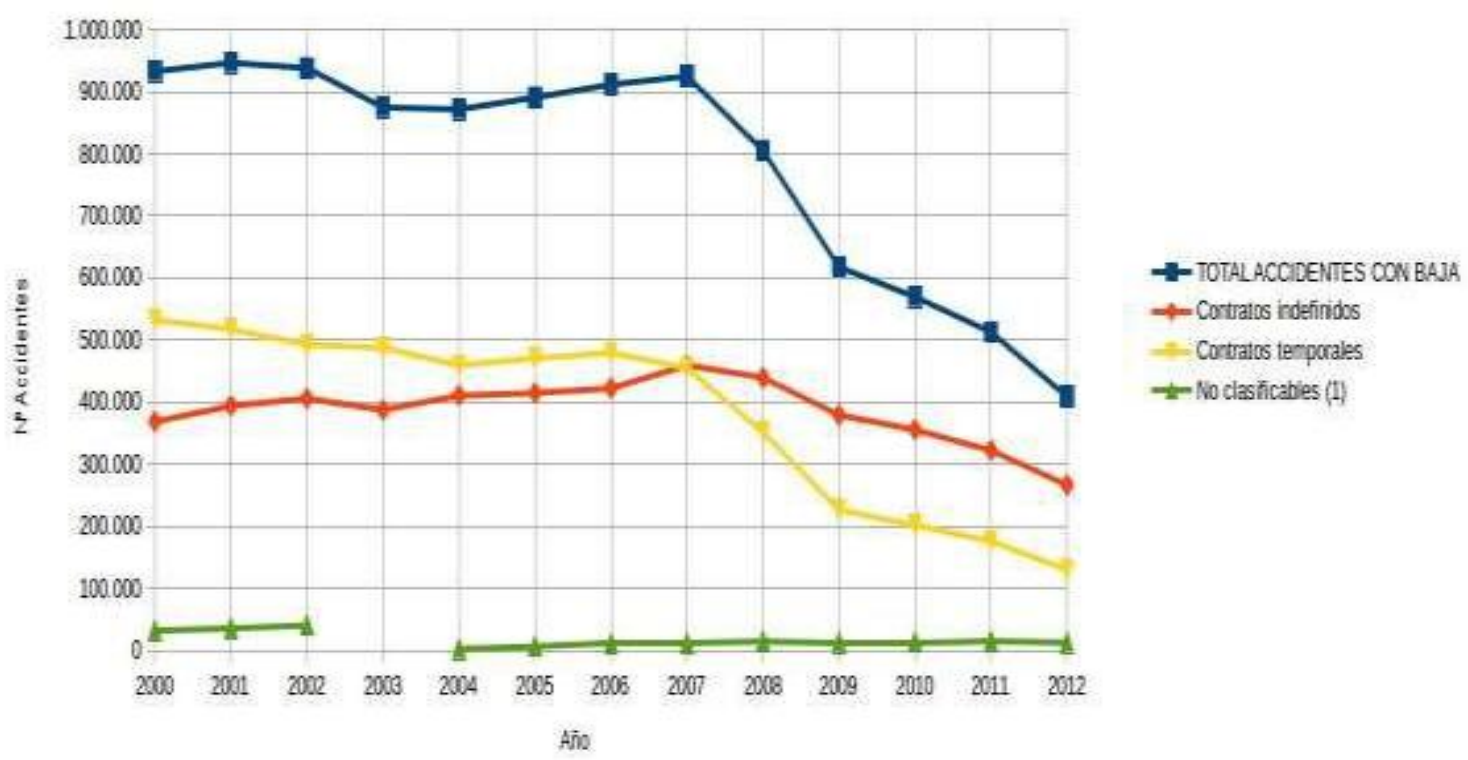

Figura 3: Índice de Incidencia Total y por Sectores 1994-2012 por cada 100.000 trabajadores. Fuente: Elaboración propia a partir de los Anuarios de Estadística del Ministerio de Trabajo 1994-2013

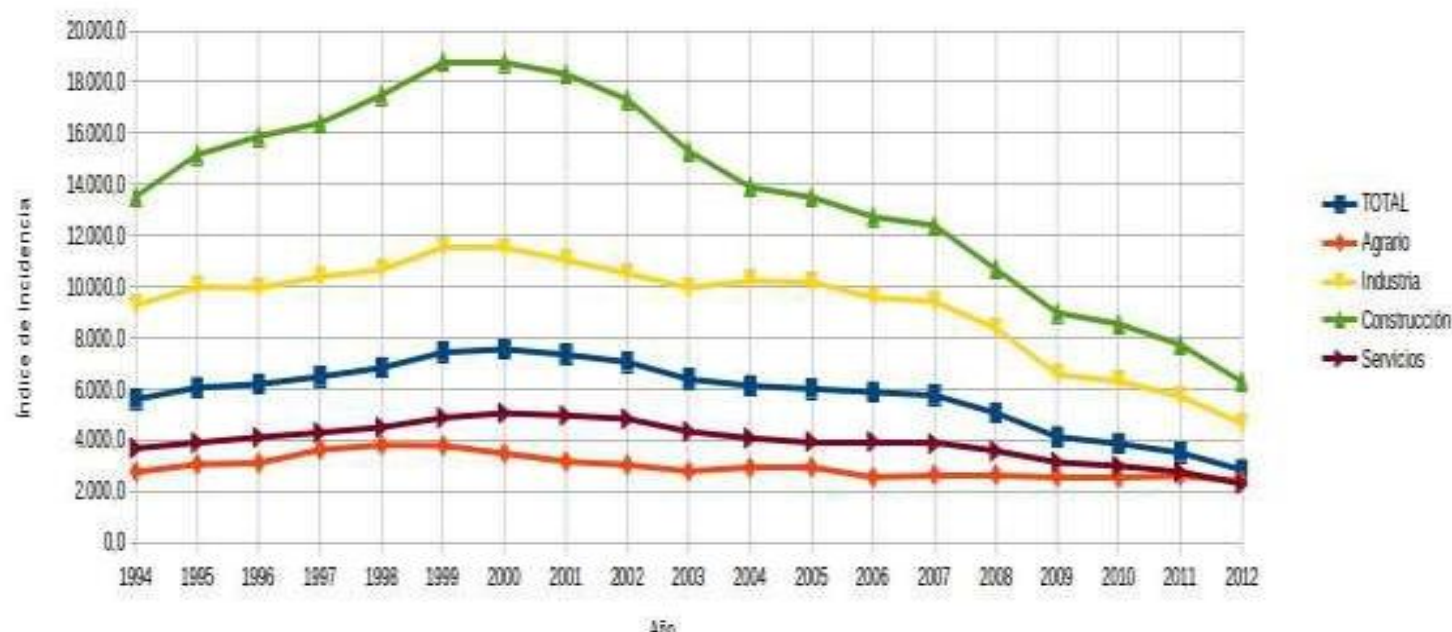


Para poder discernir mejor los datos de accidentalidad, al variar el número de trabajadores en activo en cada periodo de tiempo, en las áreas de seguridad y salud se trabaja con el denominado índice de incidencia, que expresa el número de accidentes por cada número de trabajadores.

A partir de la Figura 3 puede apreciarse que existen sectores donde la accidentalidad laboral casi no varía en el tiempo, como el de sector servicios y el agrario, pero los descensos a partir de 2007 son acusados en construcción e industria.

De estos datos cabe pensar que con la crisis económica a partir de 2008, la accidentalidad ha bajado drásticamente en los sectores más afectados por la crisis, pero para ver mejor la situación deben analizarse otros conceptos.

Figura 4: Índice de Incidencia por tipo de Contrato 1994-2012 por cada mil trabajadores. Fuente: Elaboración propia a partir de los Anuarios de Estadística del Ministerio de Trabajo 1994-2013

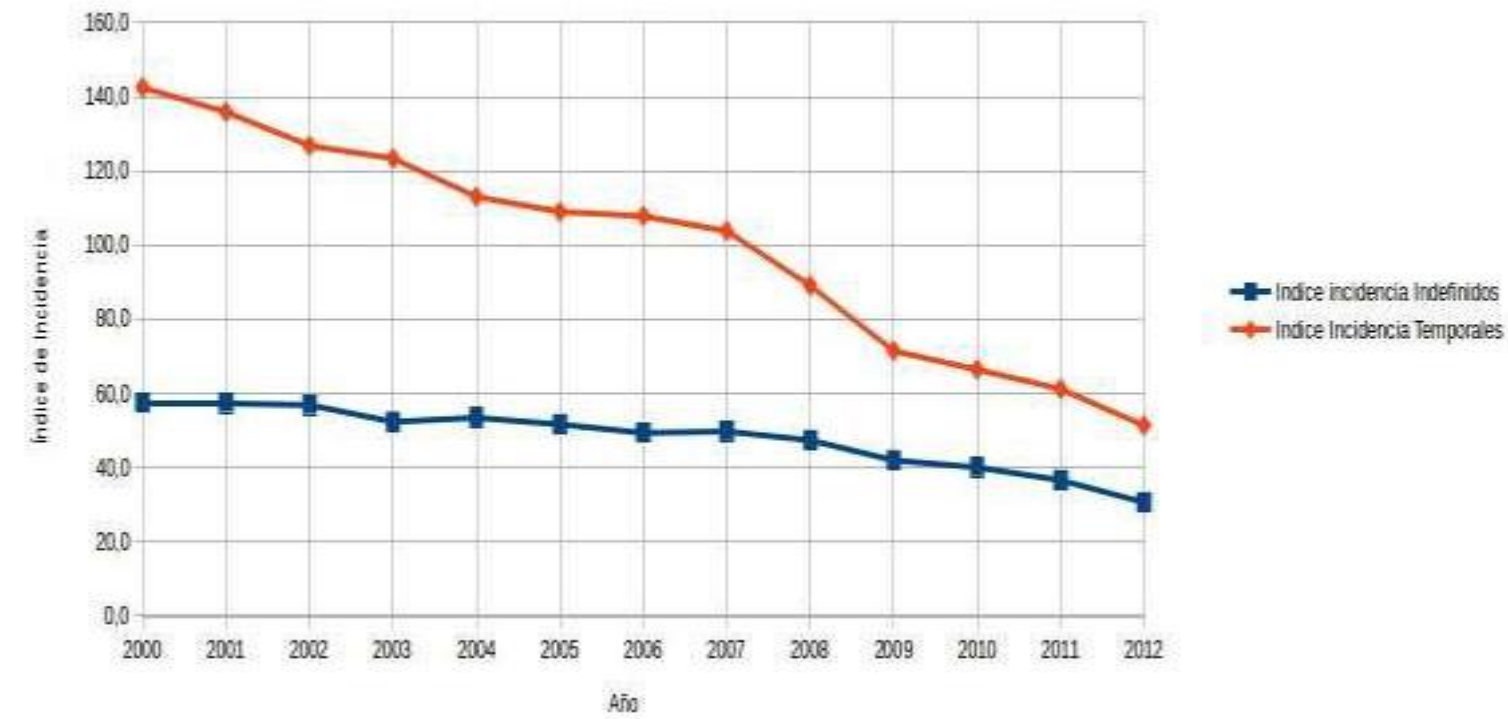

De la Figura 4 puede apreciarse que, aunque sigue la línea descendente anterior, con la crisis la bajada del índice de incidencia de accidente laboral con baja es más acusada en trabajadores con contrato temporal que en trabajadores con contrato indefinido. 
Figura 5: Índice de Incidencia por tipo de Edad 1994-2012 por cada mil trabajadores. Fuente: Elaboración propia a partir de los Anuarios de Estadística del Ministerio de Trabajo 1994-2013.

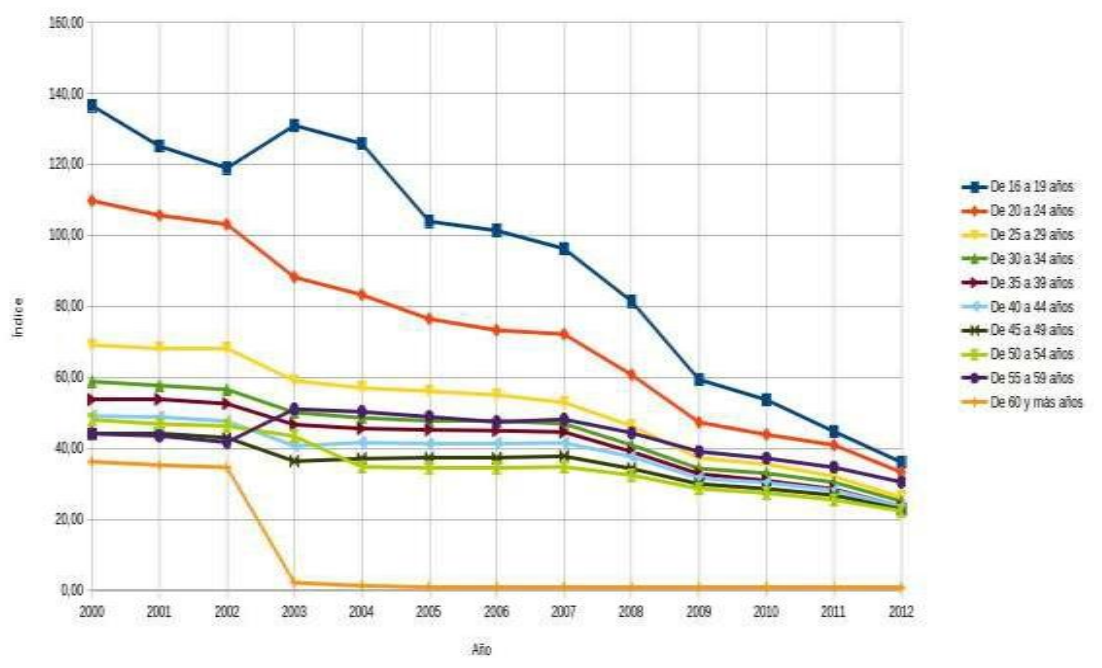

Figura 6: Índice de Incidencia por Tamaño de la Empresa 2000-2012 por cada mil trabajadores. Fuente: Elaboración propia a partir de los Anuarios de Estadística del Ministerio de Trabajo 1994-2013.

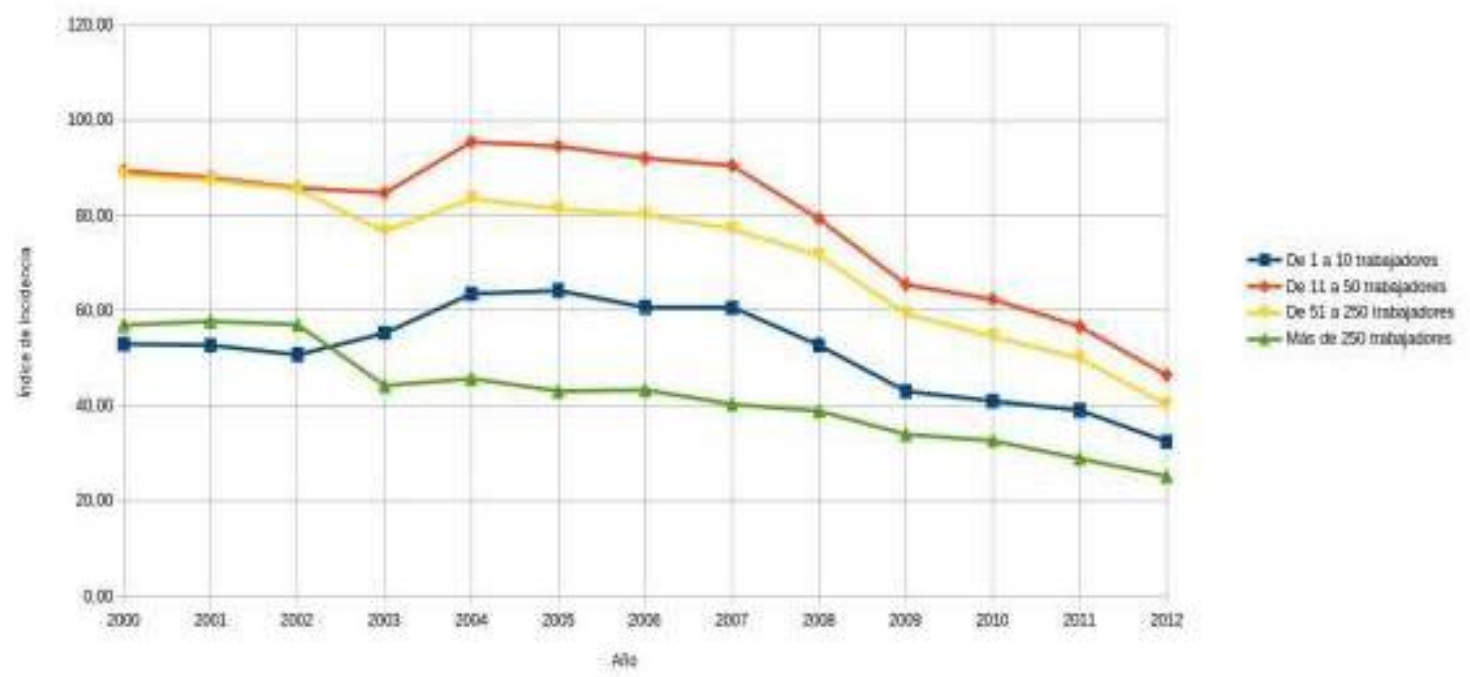

De la Figura 5 se puede apreciar que los índices de incidencia presentan descensos mucho más acusados cuanto más joven sea el trabajador.

En función del tamaño de la empresa la pequeña empresa y mediana de hasta 250 trabajadores presenta unas bajadas en los niveles de índice de incidencia muy superiores a las que superan los 250 trabajadores. 
Figura 7: Enfermedades Profesionales declaradas en España con y sin baja laboral asociada en el periodo 1994-2013. Fuente: Elaboración propia a partir de los Anuarios de Estadística del Ministerio de Trabajo 1994-2013.

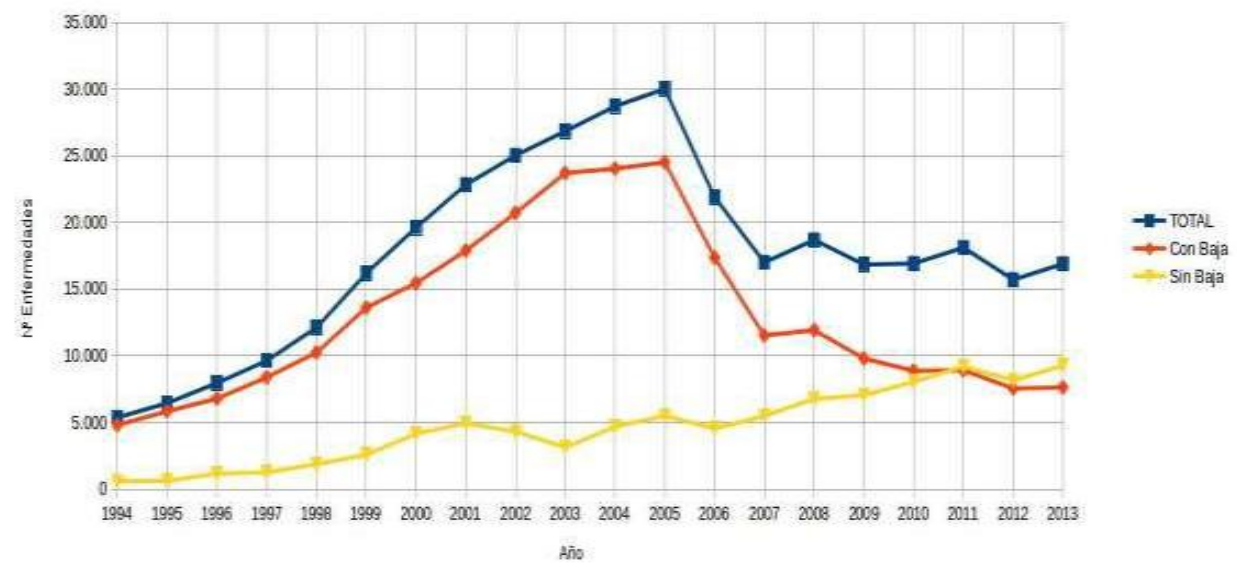

Si se analizan las enfermedades profesionales en España según la Figura 7, puede apreciarse un descenso con la crisis de las enfermedades con baja, pero un aumento significativo de enfermedades sin baja.

Las enfermedades profesionales ocasionadas por agentes físicos (aire comprimido, radiaciones ionizantes, etc.) se mantienen e incluso aumentan, pero son el resto de enfermedades profesionales (de la piel, infecciosas y parasitarias, agentes químicos, inhalación) las que se reducen principalmente en estos años (García Gómez y Castañeda López, 2008: 24).

La brusca caída de enfermedades profesionales declaradas en 2006 y posteriores años fue denunciado por los sindicatos ante la aparición de la Orden TAS/4054/2005, por la que se desarrollan los criterios técnicos para la liquidación de capitales coste de pensiones y otras prestaciones periódicas de la Seguridad Social. En esta orden del Ministerio de Trabajo se obliga a las mutuas a establecer un reaseguro de garantía sobre las pensiones por incapacidad derivadas de enfermedades profesionales, llegando entonces a ser un $25 \%$ más costosa para una mutua una enfermedad profesional frente a un accidente laboral. Igualmente se aprecia disparidad en las notificaciones de enfermedades profesionales, siendo muy superior en el norte de España frente al resto (García Gómez y Castañeda López, 2008: 41). 
De todas las anteriores figuras puede extraerse que desde el comienzo de la crisis, aunque se produce un descenso significativo de la accidentalidad laboral, esta se produce principalmente entre trabajadores de los sectores de construcción e industria y en menor medida servicios, con contratos temporales, jóvenes y de pequeñas empresas. Por contra los accidentes laborales y enfermedades profesionales que no ocasionan baja aumentan significativamente, llegando a superar en ambos casos los niveles de los que ocasionan baja. De aquí cabe deducir que los sectores y trabajadores, una vez aplicados los correctores debidos a los cambios en el número de trabajadores en activo, más afectados y sensibles por la crisis no es que se accidenten menos, sino que se están pasando a los datos sin baja.

Cabe destacar igualmente en la intervención de Castejón (2014) en el $5^{\circ}$ Encuentro Nacional de Prevención de Riesgos Laborales, que de las últimas encuestas sobre ámbito laboral puede extraerse un aumento significativo de bajas no laborales entre trabajadores por parte de sus médicos de cabecera debidos a accidente o enfermedad común.

\section{La representación de la siniestralidad laboral en la prensa}

Para una gran parte de la sociedad el conocimiento de lo que sucede en El Mundo se adquiere a través de las noticias de los medios de comunicación. De esta forma, para la mayoría de los ciudadanos "casi todo el conocimiento de lo político [y social] es construido a través de los medios" (Crespo, Moreno y Delgado, 2003: 13-14). Así los medios tienen el poder de determinar la agenda pública, influir en la sociedad y por tanto cómo los ciudadanos interpretan la realidad.

\subsection{Corpus de investigación}

Como señala Menéndez "los medios de comunicación de masas se han convertido en un agente socializador tan importante como la familia o la escuela -incluso más porque, de hecho, gran cantidad de personas conforman la pretensión de este trabajo sea la de analizar cómo se recogieron las informaciones relacionadas con la prevención y la accidentalidad laboral en cuatro diarios de tirada nacional y que 
ofrecen las cifras de tirada más altas en España: El País, El Mundo, Abc y La Vanguardia.

Son varios los motivos que avalan una investigación centrada en medios de prensa escrita. Según destaca Menéndez, ésta es "el medio de comunicación más antiguo, más tradicional y clásico”. Igualmente sostiene que "goza de mayor prestigio social y credibilidad que otros medios de comunicación más modernos como la radio y la televisión que, aun siendo más populares y atractivos, se consideran más idóneos para el entretenimiento". En esta línea, también subraya que "los diarios son más fáciles de consultar para la investigación" y que "la prensa escrita perdura, configurándose con el paso del tiempo en una fuente histórica frecuentemente consultada, característica opuesta a lo efímero "El Mundo audiovisual". (Menéndez, 2003: 33).

El criterio de elección de estos cuatro rotativos responde a su número acreditado de lectores/as. Según el Estudio General de Medios (EGM) de febrero de 2013 a noviembre de 2013, estos cuatro periódicos cuentan con una media de 1.812.000 lectores (El País), 1.107.000 (El Mundo), 752.000 (La Vanguardia) y 543.000 (Abc). Estas cifras los convierten en los cuatro rotativos de información general y ámbito nacional más leídos en España.

\subsection{Metodología empleada}

El análisis cuantitativo en la prensa diaria viene determinado principalmente por la metodología elaborada por el ya clásico texto de Kayser (1979), donde propone ante el estudio de grandes periodos de tiempo un muestreo sobre unos determinados números (Kayser, 1979: 151-152). Esta metodología fue planteada en una época en la que los periódicos solo existían en formato papel, pero hoy día se encuentran informatizados y presentan herramientas de búsqueda sobre la totalidad de los artículos. Para determinar estos artículos se han planteado diferentes esquemas en función del sistema informático de búsqueda de hemeroteca.

Abc, La Vanguardía y El Mundo: se buscan palabras y frases clave para encontrar las noticias relacionadas. Los términos empleados han sido (tanto en plular como en sigular) "accidente laboral", "accidente de 
trabajo", "enfermedad profesional" y "prevención de riesgos laborales.

El País presenta un sistema análogo al de los restantes periódicos para su archivo impreso solo en el periodo 2010-2013, pero para toda su hemeroteca presenta búsquedas por temáticas, analizándose los siguientes "riesgos laborales", "accidentes laborales", "siniestralidad laboral" y "seguridad laboral".

Tras la búsqueda de los diferentes términos sobre la hemeroteca se descartan las duplicidades, ya que una noticia puede contener varios de los términos buscados, y se clasifican los mismos según su ubicación. Siguiendo las directrices de Kayser (1979: 151), para poder comparar diferentes periódicos de ediciones múltiples se analiza la misma edición, la nacional.

Para poder analizar los resultados obtenidos a lo largo del periodo de estudio, desde la entrada de la crisis en 2008 hasta el año 2013, deben de compararse los mismos con los años anteriores a dicho periodo. De esta forma se estudian los datos desde el año 1994 hasta el 2007 para ver el histórico y los posibles cambios en las tendencias.

\section{Exposición de resultados}

A la vista del número de artículos relacionados con la seguridad y salud en el trabajo, así como su prevención, en los cuatro principales medios de comunicación de prensa escrita se puede observar un cambio en el periodo estudiado respecto de los años anteriores.

De esta forma se puede apreciar un descenso en el número de artículos a partir del año 2008 en los cuatro medios de comunicación. Aunque en los años anteriores había una mayor cantidad de artículos en el periódico El País respecto a los otros tres medios, durante los primeros años de los 2000 la distancia fue mucho menor, incluso siendo análoga a La Vanguardia. Pero es a partir del periodo de inicio de la crisis donde los cuatro medios casi se igualan en el número de artículos. El periódico El País, que había sido durante casi todos los años el que más artículo dedicaba en su edición nacional en el periodo de estudio se ha visto superado por El Mundo, La Vanguardia e igualado por $A b c$, a excepción del año 2013. 
Figura 8: Número de artículos periodísticos sobre accidentalidad laboral y prevención en el periodo 1994-2013. Fuente: Elaboración propia.

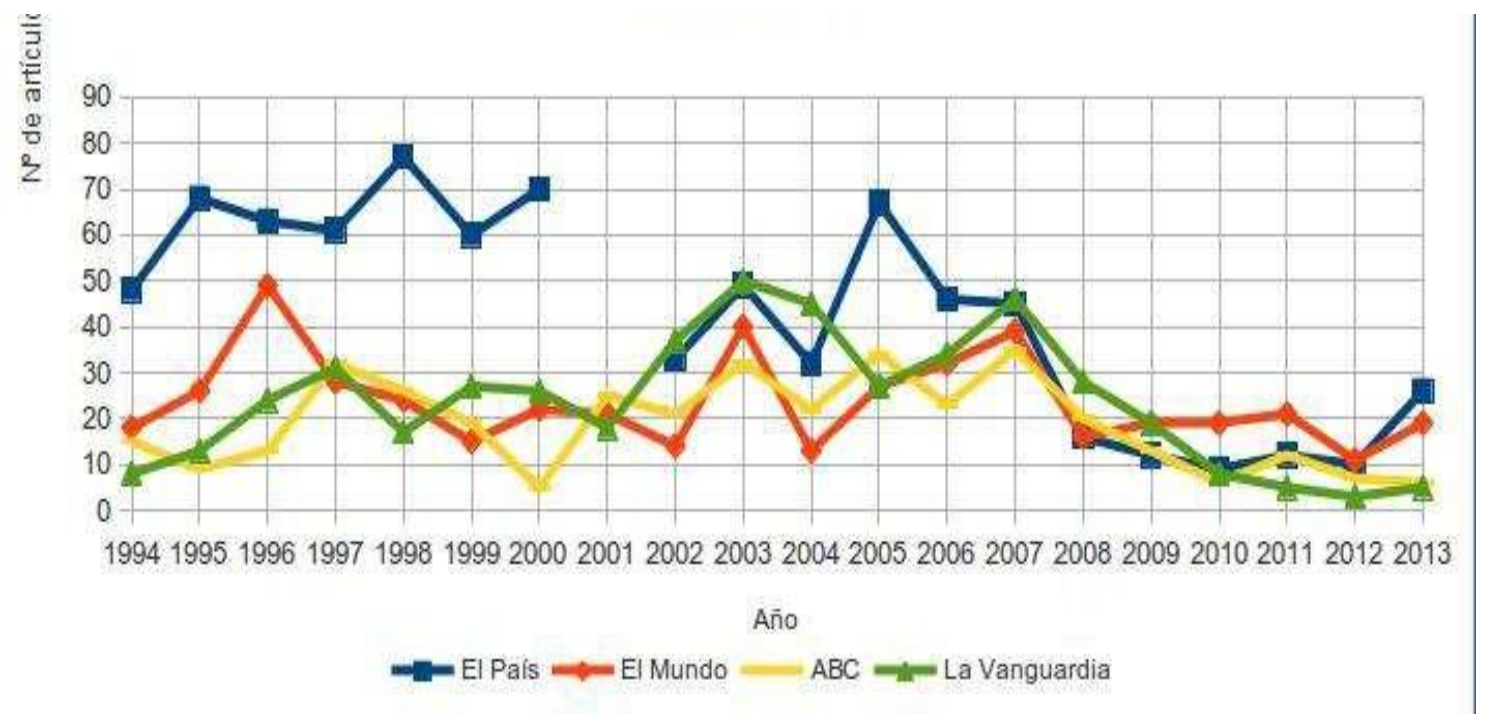

\subsection{Cambios en el tamaño de las noticias}

Si por otro lado se analiza el espacio en porcentaje que dichos artículos tienen sobre la página donde se publican también pueden encontrarse diferencias en el periodo de estudio con respecto a anteriores tiempos.

Figura 9: Porcentaje de espacio del artículo sobre la página donde se encuentra en el periodo 1994-2013, con líneas de tendencia polinómica de segundo grado asociadas. Fuente: Elaboración propia.

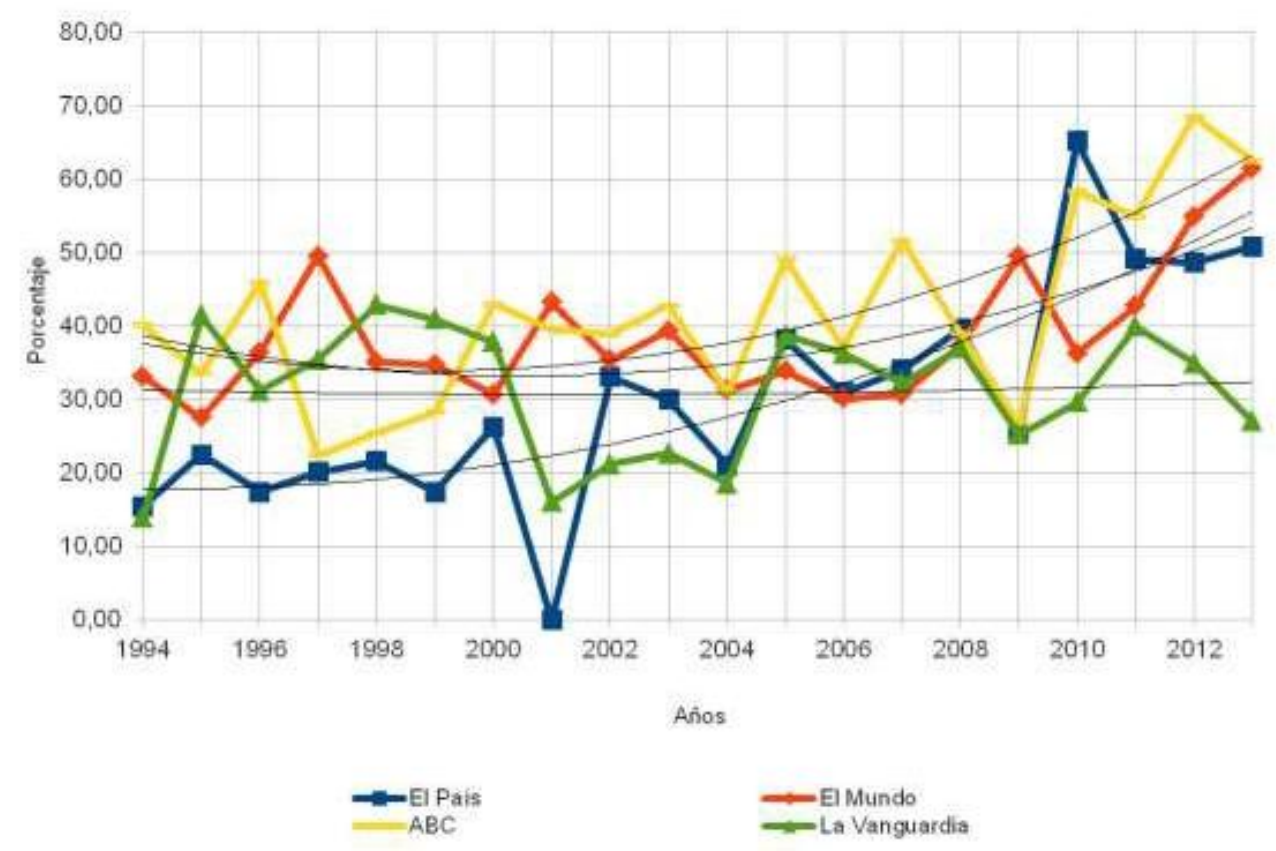


En el periodo 2008-2013 puede observarse, a excepción del periódico La Vanguardia, de un incremento en el tamaño de los artículos con respecto a los años anteriores.

Ajustando líneas de tendencia de escala polinómica de segundo grado sobre los datos de la Figura 9:

El Pais: $\mathrm{Y}=0,1127 \mathrm{X} 2 \quad 0,3812 \mathrm{X}+18,221 ; \mathrm{R} 2=0,6555$

El Mundo: $\mathrm{Y}=0,1293 \mathrm{X} 2 \quad 1,9404 \mathrm{X}+40,509 ; \mathrm{R} 2=0,4482$

Abc: $\mathrm{Y}=0,1491 \mathrm{X} 21,7782 \mathrm{X}+39,256 ; \mathrm{R} 2=0,528$

La Vanguardia: $\mathrm{Y}=0,0121 \mathrm{X} 2 \quad 0,1967 \mathrm{X}+31,509 ; \mathrm{R} 2=0,0031$

Para el periódico La Vanguardia la tendencia de número de artículos en el periodo 1994-2013 puede considerarse casi como el de una recta, siendo por contra los mayores incrementos de Abcy El País.

\subsection{Cambios en la incorporación de imágenes, fotografías o gráficos en los artículos}

Atendiendo al número de artículos que contienen imágenes, fotografías o gráficos incorporados en el periodo de estudio con respecto a años anteriores. Al igual que en el tamaño de los artículos, y de forma asociada al mismo, se observa un incremento en el número de artículos que incorporan imágenes, fotografías o gráficos para acompañar la noticia.

Solo La Vanguardia rompe esa tendencia alcista ya que, a excepción de 2011, presenta un descenso en su uso que venía siendo uno de los que más empleaba este recurso. Por contra los periódicos El País y $A b c$ presentan un incremento bastante grande, proceso que aunque se inició en los años anteriores a 2008, se acrecentó en el periodo en estudio. Por su parte El Mundo también presenta la misma tendencia, pero que partía de valores superiores. 
Figura 10: Porcentaje de artículos con objetos incorporados en el periodo 1994-2013, con líneas de tendencia polinómica de segundo grado asociadas. Fuente: Elaboración propia.

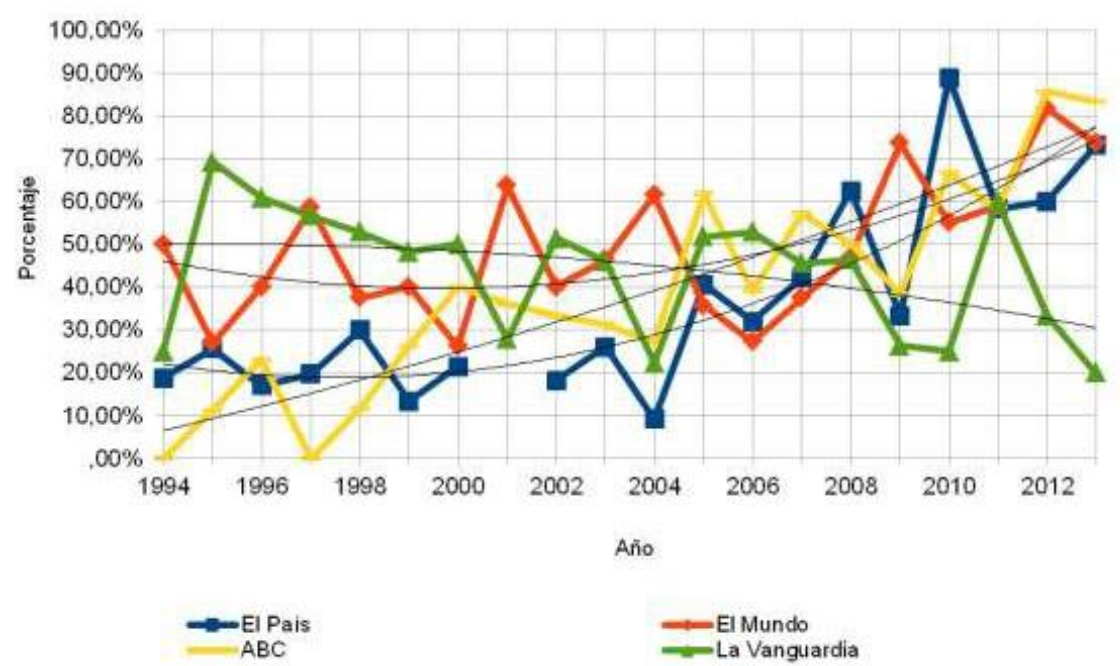

\subsection{Cambios en las secciones de los periódicos}

A lo largo del periodo de estudio los artículos sobre siniestralidad laboral y/o su prevención pueden aparecer en diferentes secciones de los periódicos. Se ha escogido el seguimiento de las principales y más representativas secciones: Economía, España, Sociedad y Opinión, uniendo todo el resto de artículos en

Figura 11: Artículos por sección del periódico $A B C$ en el periodo 1994-2013. Fuente: Elaboración propia.

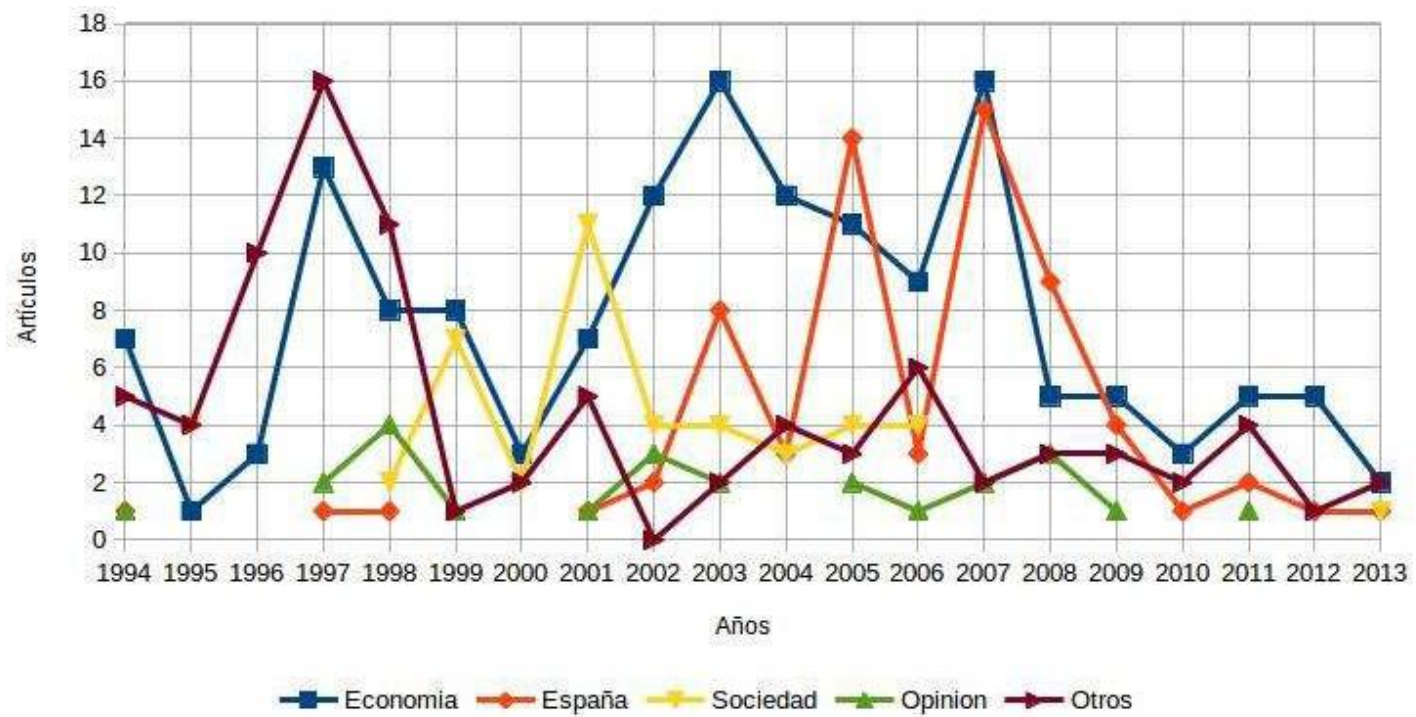

En el periódico $A b c$ la principal fuente de artículos es la sección de economía en todo el periodo de tiempo estudiado, pero a partir de 
2008 la sección España, llamada Nacional hasta el 2006, que estaba incrementando su importancia a medida que avanzaba la primera década del siglo XXI, casi ha desaparecido.

Figura 12: Artículos por sección del periódico El Mundo en el periodo 1994-2013. Fuente: Elaboración propia.

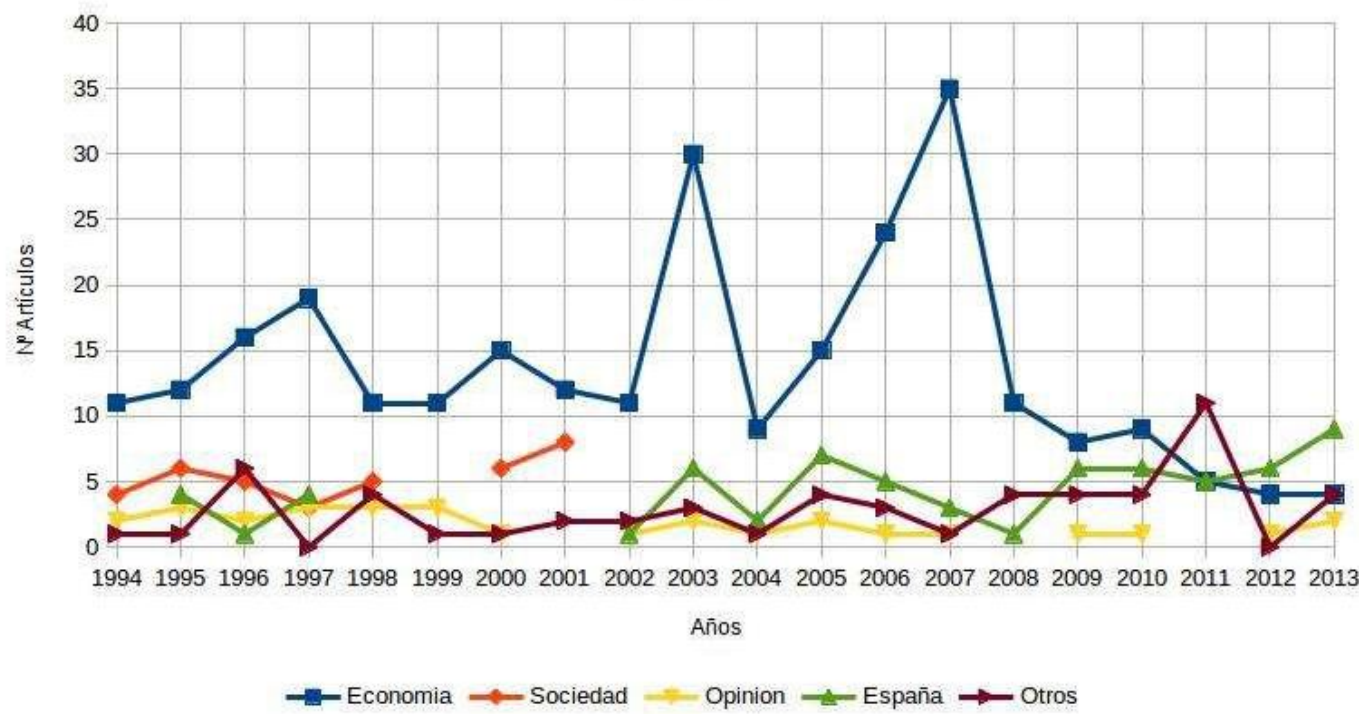

Figura 13: Artículos por sección del periódico El País en el periodo 1994-2013. Fuente: Elaboración propia.

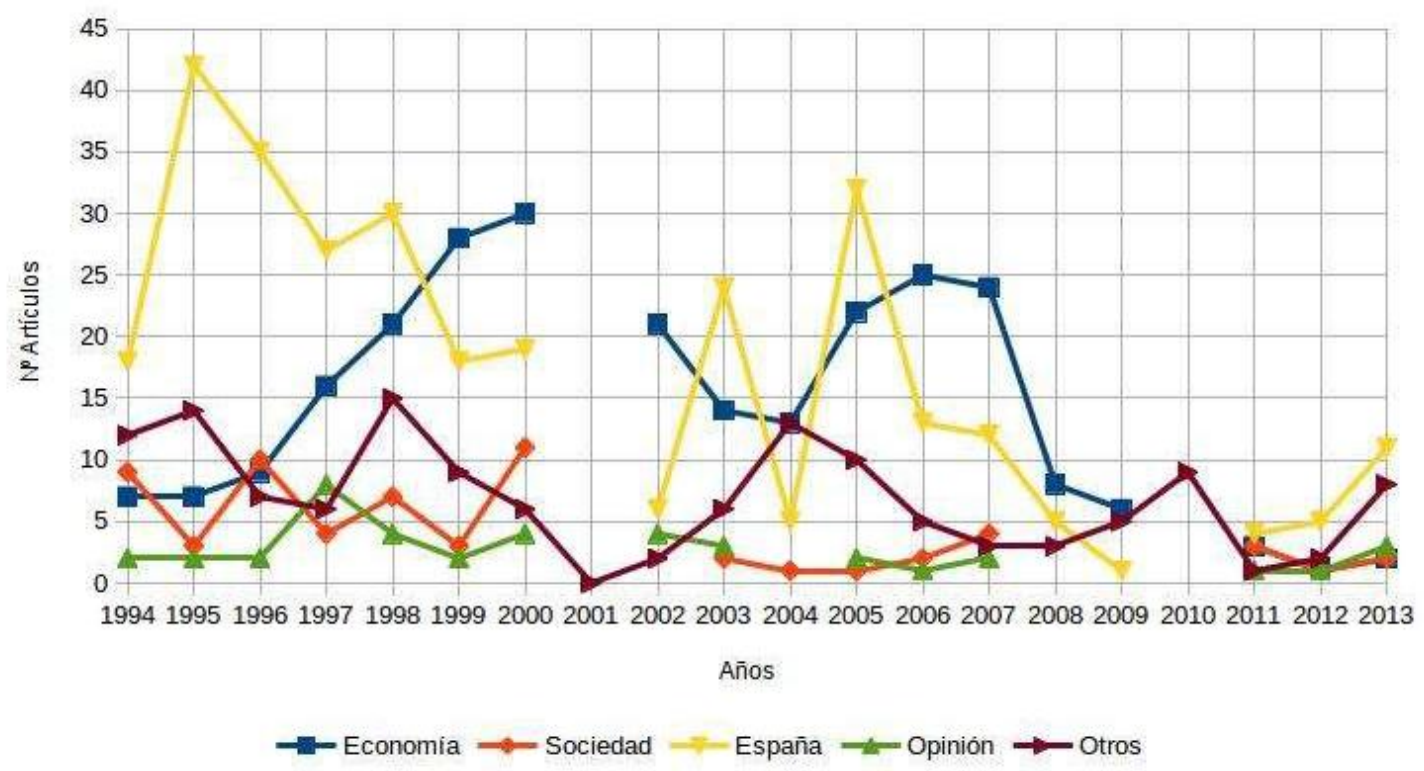

En el periódico El Mundo la principal sección que llevaba las noticias de siniestralidad laboral, Economía, descendió drásticamente a partir del año 2008, poniéndose al mismo nivel, e incluso por debajo, de otras secciones, como España. El resto permanece aproxi-madamente constante. 
Por su parte El País sufre igualmente un descenso de las noticias en las secciones de Economía y España. La primera llega incluso a desaparecer en 2010 y ser testimonial hasta 2013, mientras que la segunda tras un gran descenso y desaparecer en 2010 sufre un ligero ascenso en los últimos años. Las secciones de Opinión y Sociedad desaparecen durante varios años, manteniéndose la sección Otros (principalmente debido a la sección Internacional).

Figura 14: Artículos por sección del periódico La Vanguardia en el periodo 1994-2013. Fuente: Elaboración propia

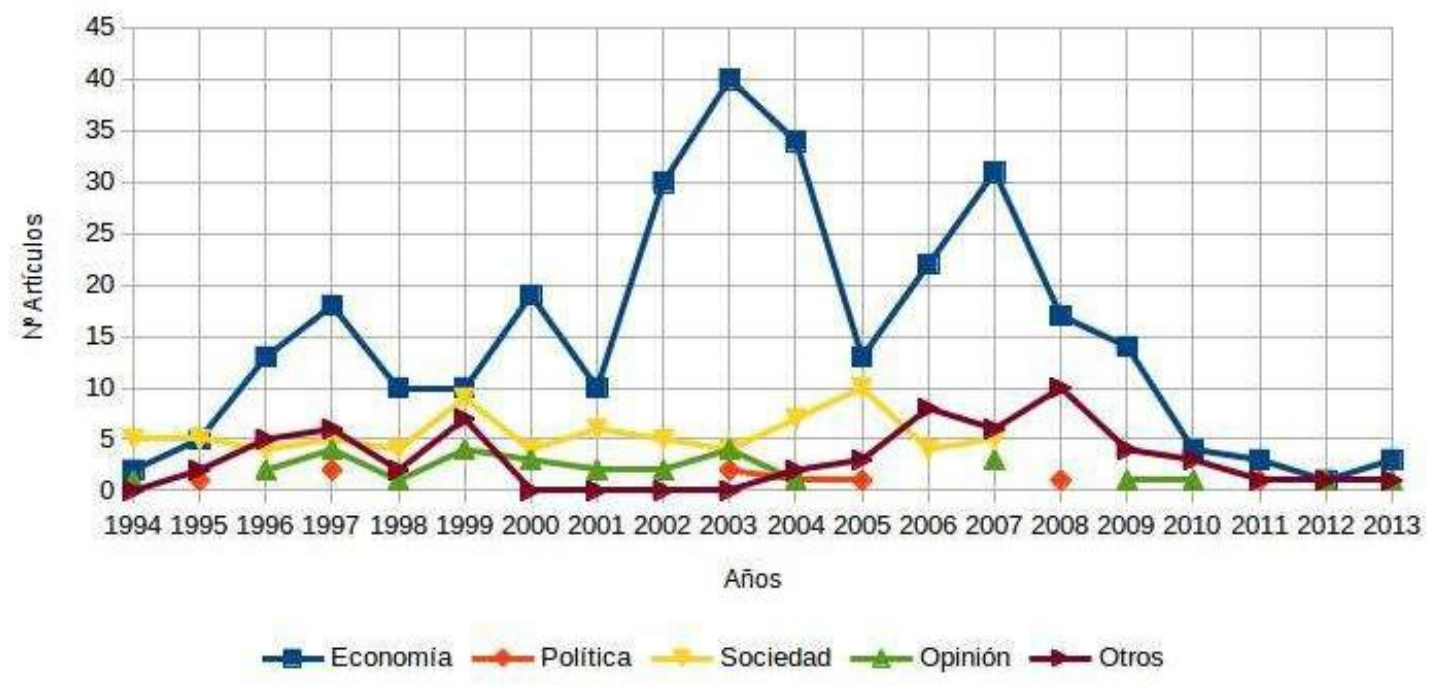

En el periódico La Vanguardia la principal sección que lleva las noticias de esta temática, Economía, igualmente desciende hasta niveles casi testimoniales. La sección Sociedad igualmente desaparece a partir de 2008.

\section{Conclusiones}

El análisis de los cuatro principales medios de comunicación escrita sobre el tratamiento de la accidentalidad laboral y su prevención en el periodo 2008- 2013 respecto a anteriores años, demuestra que el número de artículos dedicados a esta temática casi ha desaparecido respecto a anteriores años.

Comparativamente en dicho periodo la siniestralidad laboral ha disminuido en las estadísticas oficiales, debido a la menor actividad económica y menor cantidad de trabajadores en activo, pero un estudio más pormenorizado, a través de índices comparables y no en valores absolutos, muestra que el principal descenso en las bajas 
laborales en la siniestralidad se produce principalmente entre jóvenes, con contratos temporales, en empresas pequeñas y accidentes leves, pero no en personas de mayor edad, indefinidos, empresas grandes y accidentes graves. Igualmente se observa un aumento, que por primera vez supera a los siniestros con baja, de los accidentes sin baja laboral asociada. También se aprecia un aumento de bajas por causas comunes no profesionales a través de la Seguridad Social.

Esta problemática es acompañada de un cambio de atención por parte de los cuatro principales medios de comunicación escrita en España, apreciando un descenso brusco del número de artículos dedicados a esta temática, aunque por contra hay un aumento del tamaño de los artículos. Este aumento de tamaño de artículos va acompañado del incremento en el uso de imágenes, fotografías o gráficos, a excepción del diario La Vanguardia.

Las principales secciones que se ocupaban de la siniestralidad laboral y la prevención de riesgos, principalmente Economía, y en menor medida Sociedad, han casi desaparecido sus artículos, quedando lo poco que queda de la temática en el área de España y otras secciones.

Con la llegada de la crisis, a la par que han descendido los niveles globales de accidentes laborales, los índices que permiten comparar independientemente de la población activa en cada momento indican que las caídas con bajas laborales no son tan perceptibles en todos los sectores. Igualmente, se transforman en un gran incremento de accidentes laborales sin baja asociada, o declaradas como accidentes comunes por la Seguridad Social, sobre todo para los trabajadores en posición más desfavorecida. A la par el número de artículos periodísticos en los principales medios de comunicación escrita ha descendido, llegando a unos niveles de casi inexistencia. Solo como contrapartida, las noticias son más grandes sobre sus páginas en tres de los cuatro periódicos estudiados, incidiendo que tienen más fotografías, imágenes o gráficas acompañándolas.

\section{Referencias bibliográficas}

Bestraten Bellovi, M. y Turmo Sierra, E. (1982). NTP 1: Estadísticas de accidentabilidad en la empresa. Instituto Nacional de Seguridad e Higiene en el Trabajo. Recuperado el 30 de junio de 2014 de 
http://www.insht.es/InshtWeb/Contenidos/Documentacion/Fichas'Tecnicas/ NTP/ Ficheros/001a100/ntp_001.pdf

Boone, J., van Ours, J.C. Wuellrich, J-P., Zweimüller, J. (2011). Recessions are bad for workplace safety. Journal of Health Economics. 30, 764-773.

Castejón, E. (2014). Incidencia de la crisis en la prevención de riesgos laborales en España. Conferencia presentada en el $5^{\circ}$ Encuentro Nacional de Prevención de Riesgos Laborales, 25 de Septiembre, Gijón.

Crespo, I., Moreno, C. y Delgado, I. (2003). El estudio de las campañas electorales. Partidos, medios de comunicación y electores. Los efectos de la campaña electoral de 2000 en España, pp. 13-24. Buenos Aires: Planeta.

Davies, R., Jones, P. y Núñez, I. (2009). The impact of the business cycle on occupational injuries in the UK. Social Science and Medicine, 69(2), 178-182.

García Gómez M. y Castañeda López, R. (2008). Las enfermedades profesionales, declaradas en España en los últimos 18 años. La MutuaFraternidad, 19, 19-44.

Instituto Nacional de Estadística (2014). Anuarios Estadísticos 1858-1997. Recuperado el 5 de marzo de 2014 desde http://www.ine.es/inebaseweb/25687.do

Kayser, J. (1979), El diario Francés, ATE, Barcelona.

Kientz, A. (1976). Para analizar los Mass-Media. Valencia: Fernando Torres Editor

Ministerio de Empleo y Seguridad Social (2014). Anuarios de Estadística del Ministerio de Empleo y Seguridad Social 2001-2013. http://www.empleo.gob.es/es/estadisticas/contenidos/anuario.htm

Menéndez, M. I. (2003), El $4^{\circ}$ poder ¿un poder de mujeres?, Colectivu Milenta Muyeres, Oviedo.

Mora Plaza, A. (2005). Accidentalidad en España desde la Ley de Prevención: crecimiento y cambio ocupacional. La Mutua-Fraternidad, 12, 5-24.

OMS (2010), Definición de Salud de la OMS. Recuperado el 5 de marzo de 2014 desde http://www.who.int/suggestions/faq/es/

Sedano, V. et al. (2014). The impact of the economic crisis on occupational injuries. Journal of safety research, 48, 77-85.

* Texto perteneciente a tesis doctoral in progress. 


\section{Autores}

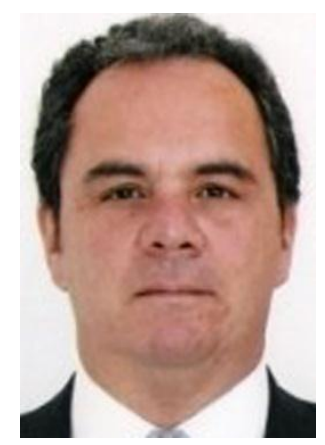

\section{Carlos Lozano Ascencio}

Doctor en Ciencias de la Información por la Universidad Complutense de Madrid y Licenciado en Ciencias de la Comunicación por la Universidad Nacional Autónoma de México. Actualmente es profesor Titular de Universidad de la carrera de Periodismo en la Universidad Rey Juan Carlos. Investigador Nivel 1, Sistema Nacional de Investigadores del Consejo Nacional de Ciencia y Tecnología (CONACYT) México. Miembro fundador del Grupo de Investigación MDCS (Mediación Dialéctica de la Comunicación Social). Actualmente es Secretario de la Sección Temática "Teorías y métodos de investigación en comunicación" de la AE-IC (Asociación Española de Investigación en Comunicación). Sus principales líneas de investigación destacan los aspectos comunicativos en contextos como: la sociedad del riesgo, la incertidumbre social y el acontecer catastrófico.

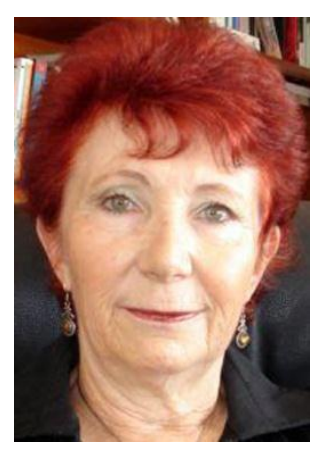

\section{Delia Crovi Druetta}

Comunicóloga y latinoamericanista. Profesora e investigadora de la Facultad de Ciencias Políticas y Sociales, Universidad Nacional Autónoma de México (UNAM). Investigadora Nacional Nivel 3, Sistema Nacional de Investigadores del Consejo Nacional de Ciencia y Tecnología (CONACYT) México; Presidenta de la Asociación Latinoamericana de Investigadores de la Comunicación (ALAIC).

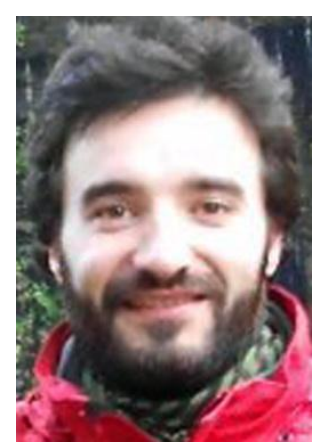

\section{Enrique Morales}

Doctor Europeo en Ciencias de la Comunicación y Sociología por la Universidad Complutense de Madrid. Actualmente es Profesor Doctor Asociado en la Universidad Camilo José Cela, en el centro adscrito U-TAD, impartiendo diversas asignaturas de Sociología y Modelos de Negocio Digitales. Es miembro activo del Grupo de Investigación MDCS de la Universidad 
Complutense de Madrid y Secretario de la Asociación Madrileña de Sociología. Sus principales líneas de investigación son: industrias culturales, TICs, cambio climático y sociología digital.

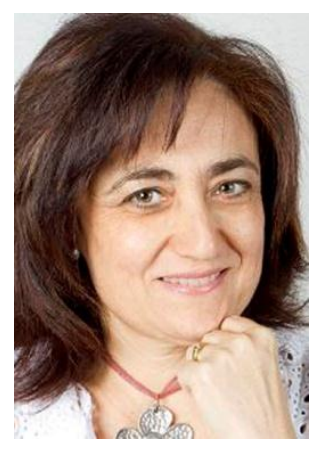

\section{$\mathbf{M}^{\mathrm{a}}$ Luisa Sánchez Calero}

Licenciada y Doctora en Ciencias de la Información (Periodismo) por la UCM. Actualmente es profesora Titular Habilitada por la ANECA desde 2013. Y posee dos tramos de investigación.

Ha participado en diferentes Proyectos de Investigación relacionados con la Información y los Medios de Comunicación. Como Investigadora forma parte de los Grupos UCM TRABUCÓM y del MDCS habiendo participado en diferentes proyectos $\mathrm{I}+\mathrm{D}+\mathrm{i}$. Entre ellos: El discurso hegemónico de los Media sobre el "Cambio Climático" (Riesgo, Incertidumbre y Conflicto). El Discurso Hegemónico a Propósito de la Verdad y la Comunicación: lo que dicen los MCM sobre la Comunicación Social. También participa como investigadora en el CIMJ (Centro de Investigación Media \& Journalism) de la Universidad Nova de Lisboa (Portugal). Y como IP ha dirigido en 2014 el proyecto financiado por la Fundación Mapfre titulado "La construcción del mensaje instructivo y ético sobre riesgos naturales en los Medios de Comunicación".

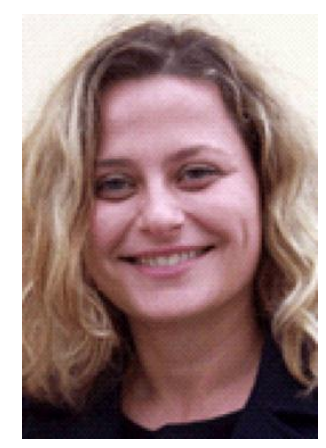

\section{$\mathbf{M}^{\mathrm{a}}$ Teresa Mercado Sáez}

Doctora en Ciencias de la Información, Licenciada en Periodismo y en Humanidades, Máster en Gestión Cultural y Especialista Universitario en Educación Ambiental y Desarrollo Sostenible.

Es profesora Agregada de Periodismo en el Departamento de Comunicación e Información Periodística de la Universidad CEU Cardenal Herrera.

Directora del Instituto CEU de Investigación de Disciplinas Económicas, Ambientales y Sociales (IDEAS), es Investigadora Principal del Proyecto del Plan Nacional 'Análisis del tratamiento informativo de las políticas energéticas en España, procesos de 
recepción y participación de organizaciones sociales' (CSO201238363).

Sus publicaciones, artículos en revistas científicas nacionales e internacionales, abordan el análisis del periodismo especializado, sobre todo cultural y ambiental. Tiene reconocido un sexenio de investigación por el CNEAI.

Premio Ángel Herrera a la Mejor Labor Docente en la Facultad de Humanidades y Ciencias de la Comunicación CEU UCH 2007.

Premio Ángel Herrera a la mejor labor de investigación en Ciencias de la Comunicación 2013.

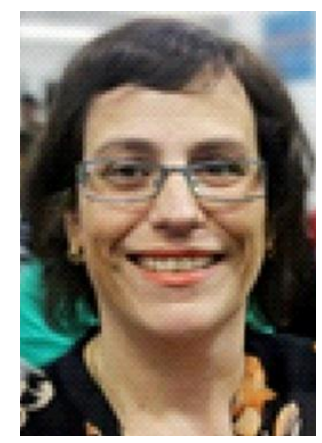

\section{Márcia Franz Amaral}

Profesora de la Universidade Federal de Santa María (Brasil), doctora en Ciencias de la Comunicación, con estancia postdoctoral en la Universitat Pompeo Fabra (Barcelona). Investigadora del Conselho Nacional de Desenvolvimento Científico e Tecnológico de Brasil.

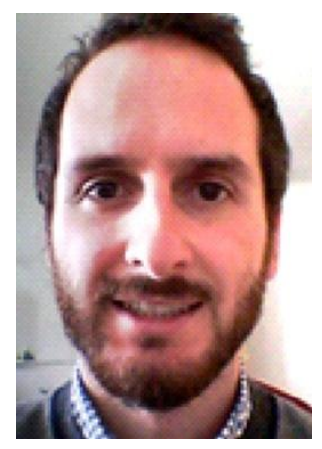

\section{Sahuquillo Verdet}

Licenciado en Periodismo por la Universidad CEU Cardenal Herrera, es doctorando y ayudante de Investigación del Departamento de Comunicación e Información Periodística de la misma Universidad.

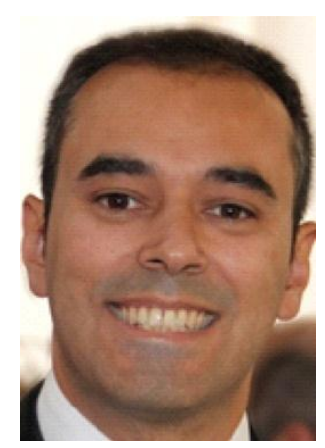

\section{Sergio Mena Muñoz}

Doctor en periodismo por la Universidad Complutense de Madrid, doctorando en historia contemporánea por la Universidad Autónoma de Madrid y licenciado en comunicación audiovisual por la Universidad Nebrija, es investigador y docente de materias relacionadas con la comunicación, el entorno 2.0 y el impacto y la percepción del mensaje en el receptor. Profesor 
acreditado por la ANECA, ha trabajado en instituciones educativas como UNIR, Universidad Complutense, Universidad Nebrija o ESNE. En su faceta profesional como periodista ha desarrollado su carrera en medios como Televisión Española, Canal 7 TV, el grupo Negocios o el grupo Intereconomía. Actualmente es socio fundador de la agencia de comunicación y marketing CBC Onlinekeepers.

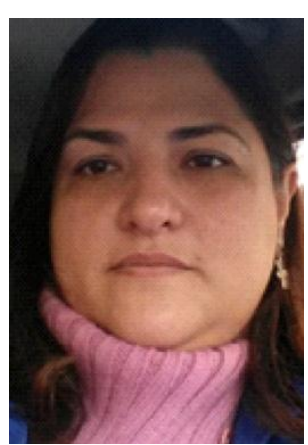

\section{Araceli Álvarez Díaz}

Doctora en Ciencias de la Información por la ULL. Licenciada en Geografía e Historia por la ULL. Ponente en varios congresos como el XIX Congreso Internacional de la Sociedad Española de Periodística, el IV Congreso de Ciberperiodismo y web 2.0 y en todas las ediciones del Congreso Internacional Latina de Comunicación Social. Autora del libro Periodismo Social: la voz del Tercer Sector, publicado en 2013. Docente en varios cursos de periodismo celebrados en la Facultad de Ciencias de la Información de la ULL y revisora de la Revista Mediterránea de Comunicación. Como periodista he desarrollado mi labor en medios como El Mundo-La Gaceta de Canarias, el gabinete de prensa de AENA en Canarias y la agencia de noticias ACN Press.

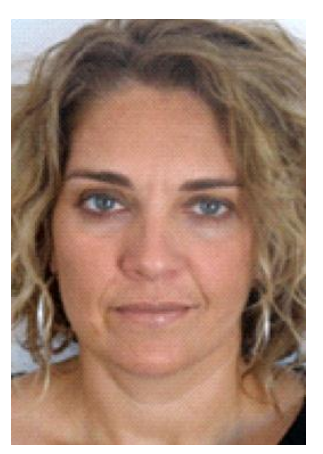

\section{Àngels Álvarez Villa}

Doctora en Ciencias de la Comunicación (UAB, 2000), Licenciada en Periodismo (UPV-CEU, 1994). Es profesora de la Universidad UCH-CEU en el Departamento de Comunicación Audiovisual, Publicidad y Tecnología de la Información desde 1994, donde imparte clases de Teoría y Técnica radiofónica, Creación Sonora y Periodismo en Radio.

Desarrolla su labor investigadora en el grupo de investigación "Sostenibilidad y Periodismo Especializado" y es también miembro del GIDYC, el grupo de investigación en Comunicación y Discapacidad de la UCH-CEU. Es autora de numerosos artículos científicos, los más recientes The fracking debate in the media: The role of citizen platforms as sources of information ESSACHESS. 
Journal for Communication Studies, vol. 7, no. 1(13) / 2014 y "Los científicos como actores y fuentes en el discurso mediático sobre la energía nuclear", Prisma Social 1989-3469 (2014) Num. 12.

Galardonada con el XVI Premio Ángel Herrera a la Investigación en la modalidad de Ciencias de la Comunicación 2013, y Premio a la calidad en investigación sobre Cooperación Internacional para el desarrollo Humano concedido por la Conferencia de los Rectores de las universidades madrileñas (CRUMA).

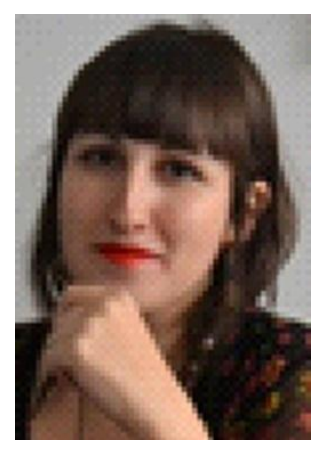

\section{Delicia Aguado Peláez}

Licenciada en Periodismo y en Ciencias Políticas y de la Administración por la Universidad del País Vasco (UPV/EHU). Cuenta con el máster en Participación y Desarrollo Comunitario y el Diploma en Estudios Avanzados en Comunicación Audiovisual y Publicidad por la misma universidad. Actualmente, se encuentra realizando la tesis doctoral titulada "Impacto del Post-11S en la ficción norteamericana. Análisis de Perdidos (Lost, Abc: 2004-2010) y de otras series de la Tercera Edad Dorada". Sus líneas de investigación versan sobre animación infantil, estudios culturales, feminismo, influencia del terrorismo en la cultura popular y narrativas transmedia.

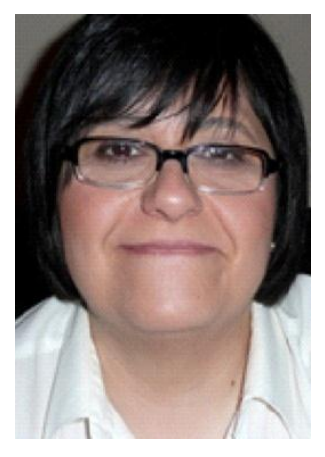

\section{$\mathbf{M}^{\mathbf{a}}$ José Pou Amérigo}

Doctora en Ciencias de la Información y profesora de Periodismo en la CEU-UCH desde 1993. Pertenece al grupo de investigación "Sostenibilidad y Periodismo Especializado". Ha centrado sus investigaciones en el análisis del discurso periodístico en el ámbito de la comunicación intercultural y en la evolución de los géneros periodísticos. Ha publicado numerosos artículos en revistas científicas como "Indagaciones interculturales sobre orígenes y religiones en el humor periodístico" (2011) o "El hecho religioso y su tratamiento periodístico: limitaciones y dificultades" (2008). Ha colaborado en obras colectivas con trabajos como "Green Pope o el 
liderazgo ambientalista de Benedicto XVI" (2012) y "La creatividad en la opinión del medio: el suelto y los nuevos formatos para Internet" (2007). Es columnista del diario Las Provincias, de Valencia.

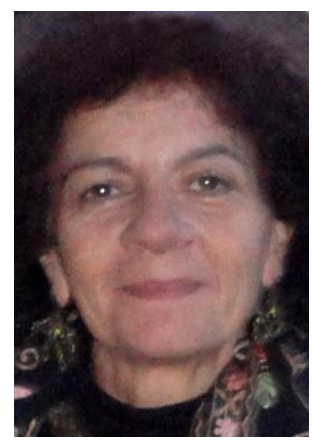

\section{Estrella Israel Garzón}

Doctora en Ciencias de la Información por la Universidad Complutense de Madrid. Profesora de Periodismo e Investigadora en la Universidad CEUCardenal Herrera de Valencia. Autora de Comunicación y Periodismo en una sociedad global. Comunicar la diferencia (2001, 2006) e introductora del concepto periodismo intercultural. Profesora invitada en la Universidad Popular Autónoma de Puebla (México), Universidad Austral de Chile y en la Université de Lorraine (Francia). Sus investigaciones se centran en la comunicación intercultural, la construcción periodística de la diferencia, el periodismo social así como en la calidad informativa y la representación mediática de la diversidad. Colabora en la actualidad con el grupo de investigación "Sostenibilidad y Periodismo Especializado" de la UCH-CEU

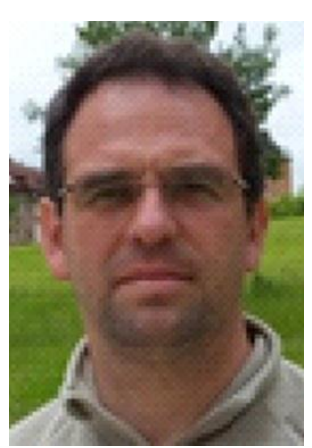

\section{Sergio Arce García}

Doctorando en Humanidades y Comunicación por la Universidad de Burgos, con investigación de tesis sobre el impacto de los accidentes laborales en la prensa escrita en el periodo 1994-2013. Licenciado en Ciencias Químicas por la Universidad de Valladolid y Postgrado Universitario en Sistemas de Gestión por la Universidad Internacional de La Rioja (UNIR). Técnico Superior en Prevención de Riesgos Laborales en seguridad, higiene y ergonomía y psicosociología aplicada. Profesor de postgrado en UNIR en Prevención de Riesgos Laborales y Sistemas de Gestión.orcid.org/0000-0003-0578-9787 